\author{
UNIVERSIDADE DE SÃO PAULO \\ FACULDADE DE FILOSOFIA LETRAS E CIÊNCIAS HUMANAS \\ DEPARTAMENTO DE FILOSOFIA \\ PROGRAMA DE PÓS-GRADUAÇÃO EM FILOSOFIA
}

MIZAEL ARAÚJO DE SOUZA

\title{
A sensação no pensamento de Agostinho de Hipona: uma análise a partir do livro XI do De Trinitate
}

(versão corrigida)

São Paulo

2018 
UNIVERSIDADE DE SÃO PAULO

FACULDADE DE FILOSOFIA LETRAS E CIÊNCIAS HUMANAS

DEPARTAMENTO DE FILOSOFIA

PROGRAMA DE PÓS-GRADUAÇÃO EM FILOSOFIA

\title{
A sensação no pensamento de Agostinho de Hipona: uma análise a partir do livro XI do De Trinitate
}

\author{
Versão Corrigida
}

Mizael Araújo de Souza

Dissertação apresentada ao Programa de Pós-Graduação do Departamento de Filosofia, Letras e Ciências Humanas da Universidade de São Paulo, para obtenção do título de Mestre em Filosofia.

Área de Concentração: História da Filosofia.

De acordo

Orientador: Prof. Dr. Moacyr Ayres Novaes Filho

São Paulo

2018 
Autorizo a reprodução e divulgação total ou parcial deste trabalho, por qualquer meio convencional ou eletrônico, para fins de estudo e pesquisa, desde que citada a fonte.

Catalogação na Publicação Serviço de Biblioteca e Documentação

Faculdade de Filosofia, Letras e Ciências Humanas da Universidade de São Paulo

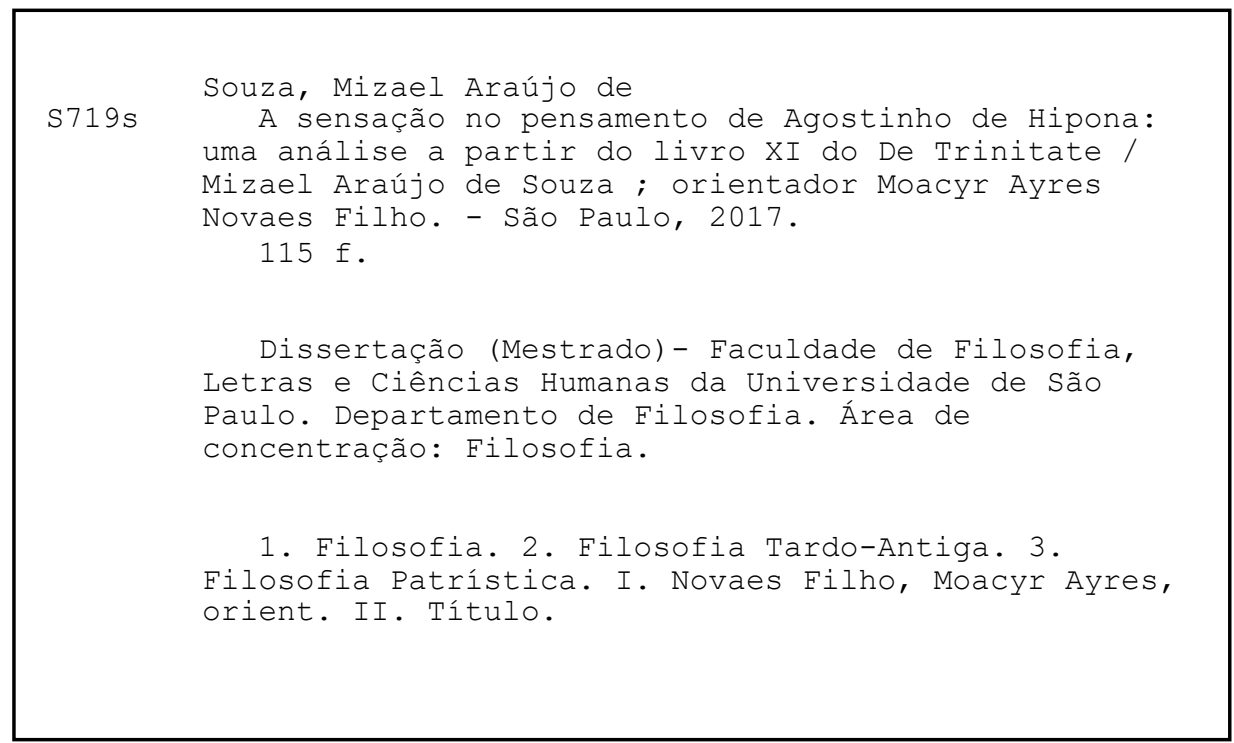


Nome: SOUZA, Mizael Araújo de

Título: A sensação no pensamento de Agostinho de Hipona: uma análise a partir do livro XI do De Trinitate.

Dissertação apresentada ao Programa de Pós-Graduação do Departamento de Filosofia, Letras e Ciências Humanas da Universidade de São Paulo, para obtenção do título de Mestre em Filosofia.

Aprovado em:

$$
\text { Banca Examinadora }
$$

PROF. DR. MOACYR AYRES NOVAES FILHO

Orientador

PROF. DR. LORENZO MAMMI

$1^{\circ}$. Titular

PROF. DR. PEDRO CALIXTO FERREIRA FILHO

$2^{\circ}$. Titular

PROF. DR. LUIZ MARCOS DA SILVA FILHO

$3^{\circ}$. Titular 
Aos meus pais, Elita e Bartolomeu, Exemplos de amor e abnegação E sem os quais não chegaria aqui. Dedido esse trabalho com carinho. 


\section{AGRADECIMENTOS}

Será possível citar todos os que contribuíram direta e indiretamente para que eu pudesse chegar até aqui? Não sei! Talvez eu cometa alguma injustiça, certamente. Mas depois de algum tempo estudando Agostinho posso dizer que uma das coisas que aprendi foi que o ser humano apesar de limitado e falível ainda pode falar.

Em primeiro lugar agradeço ao meu orientador, Moacyr Novaes, sem o qual essa dissertação não teria sido possível. Desde o primeiro contato que tive com ele, quando ainda cursava teologia e nem tinha sequer me matriculado para prestar a FUVEST, foi quem me recebeu com toda a deferência ao expressar meu desejo em estudar Agostinho sem nem mesmo ter a noção do que era uma pós-graduação em filosofia numa universidade de ponta como a USP. O seu rigor filosófico e de pesquisador foi fundamental na minha formação, ajudando-me não somente em em minhas deficiências filosóficas, mas até de composição textual Caro mestre, não sei se posso dimensionar o tamanho da sua influência na minha vida acadêmica.

No âmbito filosófico e da amicitia, não posso deixar de citar Daniel Fugisaka. Meu caro, nossos caminhos se cruzaram quando eu ainda estava na graduação e sua amizade foi um presente gracioso que, além da partilha existencial, ajudou-me na maturação das ideias e linguagem acadêmica desde a iniciação científica. Agostinho se tornou nosso companheiro de pensamento.

E como poderia deixar de fazer menção aos meus amigos de longa data, Francisco Leite e Rogério Lima de Moura? Desde a graduação em teologia temos caminhado juntos na vida profissional e acadêmica. Francisco Leite grande amigo de todas as horas, o que posso dizer de você? Sem palavras.

Também não posso deixar de citar meus amigos Richard Lazarini, leitor atento de Tomás de Aquino e companheiro de divagações filosóficas, uma grande alma, e Renato Bento Fernandes, primeiro amigo que tive em São Paulo e grande incentivador. Obrigado.

Ainda devo fazer menção especial ao meu primo Jonas Carvalho. Será ali que começei a me interessar por filosofia? Lembro-me de, ainda em Manaus, você ter falado a encantadora palavra. Daquele momento em diante, o que estava num ictus atemporal tornou-se uma vocação. Sim meu primo, você talvez não saiba, mas foi quem me conduziu à filosofia.

Agradeço também aos amigos Alexandre da Silva Chaves e José Teles. Aos colegas e amigos de CEPAME pelo frutoso diálogo filosófico. Aos professores José Carlos Estêvão, 
Carlos Eduardo de Oliveira e Lorenzo Mammi sempre incentivadores e abertos ao diálogo, além das inestimáveis arguições.

Também agradeço aos professores Pedro Calixto e Luiz Marcos, arguidores em minha banca pelas sugestões e observações feitas, e a finesse no trato e na arguição.

Ao CNPq (Conselho Nacional de Desenvolvimento Científico e Tecnológico) pela bolsa concedida que permitiu a concretização dessa investigação.

Ao pessoal da secretaria, a Geni, Marie e Luciana sempre dispostas a auxiliar nas mais diversas questões, inclusive meus lapsos com datas. Sou-lhes imensamente grato.

À família da IPU Jundiaí que sempre compreendeu minhas ausências na necessidade de redigir a dissertação.

Aos meus pais que com todas as dificuldades sempre me apoiaram quando queria fazer cursos "que não dão dinheiro". Aos meus familiares em geral. E não poderia deixar de citar a minha amiga Ozenir Araújo que, de longa data, sempre tem me incentivado a apoiado.

Aos meus alunos que sempre me perguntam: "quando vai ser a defesa?".

A todos que de alguma forma, direta e indiretamente, estiveram presentes até aqui. Muito obrigado. 
O meu olhar é nítido como um girassol.

Tenho o costume de andar pelas estradas Olhando para a direita e para a esquerda, E de vez em quando olhando para trás... E o que vejo a cada momento É aquilo que nunca antes eu tinha visto,

E eu sei dar por isso muito bem... Sei ter o pasmo essencial Que tem uma criança se, ao nascer, Reparasse que nascera deveras... Sinto-me nascido a cada momento Para a eterna novidade do mundo 


\section{RESUMO}

SOUZA, Mizael Araújo de. A sensação no pensamento de Agostinho de Hipona: uma análise a partir do livro XI do De Trinitate. 2017. 122f. Dissertação (Mestrado em Filosofia) - Faculdade de Filosofia, Letras e Ciências Humanas, Universidade de São Paulo, São Paulo, 2017.

Como pensar uma atividade que lida com corpos, como é o caso da sensação, numa filosofia que está em constante busca e valoriza como superior o que é incorporal? Não seria de se esperar que em tal filosofia esse problema fosse relegado ao ostracismo ou simplesmente ignorado? Não é o que parece acontecer. Contudo, tal problema nos parece ser pouco estudado. É na busca por resolvê-lo de modo mais aprofundado que se coloca o presente trabalho. Ao que parece, os textos agostinianos tentam mostrar que a sensação é uma atividade da alma. Mas como isso é possível se a alma é incorporal e aquilo que ela sente é corpóreo? Relacionando isso ao problema inicial é necessário ver em que medida essa atividade pode adquirir alguma relevância filosófica. Nossa tese é que tal relevância é afirmada justamente pelo fato de ser uma atividade anímica, já que a alma é superior aos corpos. Mas acima de tudo, essa relevância parece alcançar toda a sua amplitude na obra de maturidade intitulada De trinitate. Tentaremos demonstrar que nela Agostinho propõe uma solução que, no seu pensamento, seria definitiva sobre o problema. Ali ele o redimensiona a partir das tríades humanas que são análogas à Trindade Divina - a consideração da sensação se dando em uma dessas tríades inseridas num processo de ascenção interiorizante. Contudo, como isso acontece e se justifica é o que pretendemos expôr no que se segue.

Palavras-chave: Agostinho. Sensação. Ascensão Interiorizante. Exterior-Interior. Corporais. Incorporais. Trindade. 


\begin{abstract}
SOUZA, Mizael Araújo de. The sensation in the thought of Augustine of Hippo: an analysis from book XI of De Trinitate. 2017. 122f. Dissertação (Mestrado em Filosofia) Faculdade de Filosofia, Letras e Ciências Humanas, Universidade de São Paulo, São Paulo, 2017.

How to think of an activity that deals with bodies, as is the case of sensation, in a philosophy that is constantly seeking and values as superior what is incorporeal? Is it not to be expected that in such philosophy this problem would be ostracized or simply ignored? It is not what seems to happen. However, this problem seems to be little studied. It is in the search for solving it in a more in-depth way that the present work is placed. It seems that the Augustinian texts try to show that sensation is an activity of the soul. But how is this possible if the soul is incorporeal and what it feels is corporeal? Relating this to the initial problem is necessary to see to what extent this activity can acquire some philosophical relevance. Our thesis is that such relevance is affirmed precisely because it is an activity of soul, since the soul is superior to the bodies. But above all, this relevance seems to reach its full extent in the work of maturity entitled De trinitate. We will try to demonstrate that in it Augustine proposes a solution that, in his thought, would be definitive about the problem. There he reshapes it from the human triads that are analogous to the Divine Trinity - the consideration of sensation taking place in one of these triads inserted in a process of interiorising ascension. However, how this happens and is justified is what we intend to expose in what follows.
\end{abstract}

Keywords: Augustine. Sensation. Interiorising Ascension. Exterior-Interior. Corporeal. Incorporeal. Trinity. 


\section{Lista de Abreviações de textos de Agostinho de Hipona}

As obras seguem a lista constante no Augustinus-Lexikon editado por Cornelius Mayer, vol. 3, Basel: Schwabe Verlag, 2004-2010.

[http://www.augustinus.de/images/WerkeverzeichnisAL3.pdf]

an. quant. De animae quantitate liber unus

beata $u$ De beata uita liber unus

ciu. De ciuitate dei libri uiginti duo

conf. $\quad$ Confessionum libri tredecim

diu. qu. De diuersis quaestionibus octoginta

tribus liber unus

doctr. chr. De doctrina christiana libri

duab. an. De duabus animabus liber unus

Gn. litt. De Genesi ad litteram libri duodecim

lib. arb. De libero arbitrio libri tres

mus. De musica libri sex

trin. De trinitate libri quindecim
CSEL 89,131-231 [9]

CCL 29,65-85 [11]

CCL 47,1-314; 48,321-866

CCL 27,1-273 [18]

CCL 44A, 11-249 [29]

Simonetti 6-362 [31]

CSEL 25,1,51-80 [34]

CSEL 28,1,3-435 [156] [b]

CSEL 74,3-154 [172] [c]

PL 32,1081-1194 [181]

CCL 50,(3-)25-380; 
1. A SENSAÇÃO CONSIDERAdA A PARTIR DA DISTINÇÃO ENTRE HOMEM INTERIOR E EXTERIOR NO DE TRINITATE

1.1. Interior e Exterior, Considerados a partir da Relação da Alma Humana com Deus. 17

1.2. Imago dei no homem interior e uestigium trinitatis, trinitatis effigiem ou aliquo modo simile no homem exterior

1.3. A Dinâmica Relacional entre Exterior e Interior

1.4. Distinção entre Homem Interior e Exterior dentro da Unidade da Alma 23

1.5. Ascensão Interiorizante como Característica Fundamental do Projeto Agostiniano 26

1.5.1. Ascensão interiorizante do De animae quantitate 27

1.5.2. Ascensão Interiorizante no De trinitate

1.6. A Condição de Presente como Justificativa para a consideração da ascensão interiorizante a partir do exterior

2. A RELEVÂNCIA FILOSÓFICA DA SENSAÇÃO A PARTIR DA ASCENSÃO INTERIORIZANTE

2.1. As Imagens Trinitárias na Primeira Trindade Exterior 38

2.2. A Sensação em Analogia com a Doutrina da Inseparabilidade das Operações Trinitárias

2.2.1. O Problema da Inseparabilidade das Operações Trinitárias antes de Agostinho 42

2.2.2. A Inseparabilidade das Operações Trinitárias no Livro I do De trinitate 44

2.2.3. A Inseparabilidade das Operações Trinitárias nas Trindades Exteriores 46

2.3. A Sensação na Primeira Trindade Exterior 


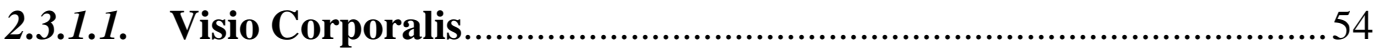

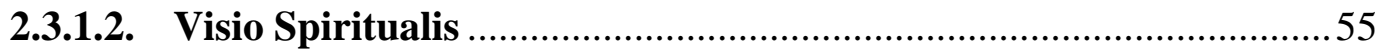

2.3.2. Unidade dos Sentidos e Sentido Interior ........................................5

2.3.3. A Superioridade do Sentido da Visão Sobre os Outros Sentidos ......60

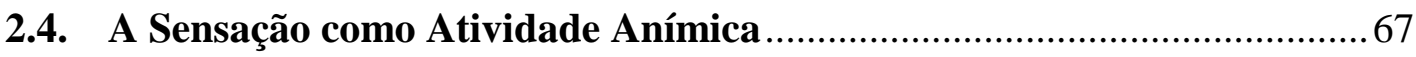

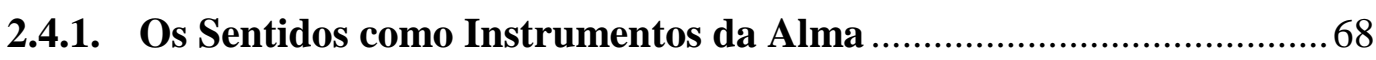

2.4.2. A Alma que Sente é Superior ao Corpo.......................................... 71

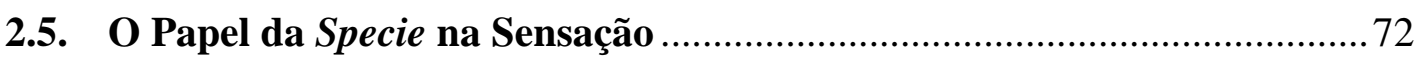

2.5.1. Sensação e Cosmologia Corporalista no Estoicismo …....................... 74

2.5.1.1. Sensação e Impressão Cataléptica no Estoicismo …........................76

2.5.2. O Exemplo do Sinete sobre a Água e a Enformação do Sentido ........78

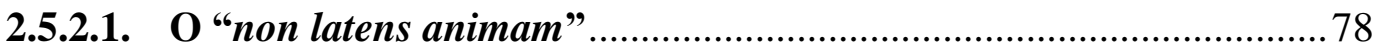

2.5.2.2. Preservação da Autonomia da Alma no problema da Enformação dos Sentidos 80

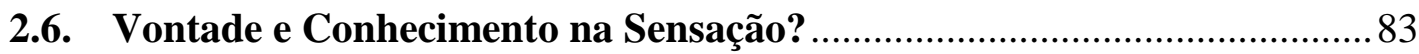

2.6.1. O Papel da Vontade na Sensaçãa...................................................... 83

2.6.2. Conhecimento na Sensação: Considerações a partir do De musica .. 86

3. A PASSAGEM E "PRESENÇA" DA SENSAÇÃO NA SEGUNDA

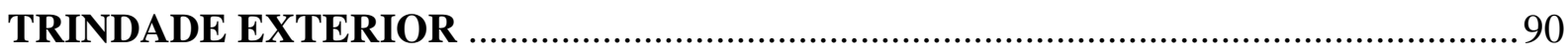

3.1. A Cogitatio na Segunda Trindade Exterior ........................................... 90

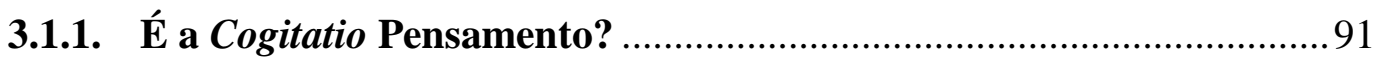

3.1.1.1. O Papel da Vontade na Distinção Entre Cogitatio Humana e Recordação Animal: Cogitatio Humana como Atividade da Alma Racional. ........... 93

3.2. A Sensação na Passagem da Primeira para a Segunda Trindade Exterior 98

3.2.1. As Species como o que Proporciona a Primeira Passagem Ascensional 99 
CONCLUSÕES .

103

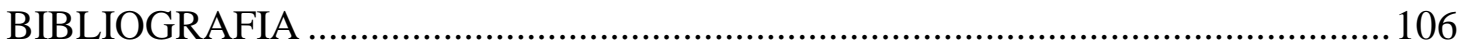




\section{INTRODUÇÃO}

A sensação é um tema recorrente no pensamento de Agostinho. Apesar disso, em um primeiro contato com a filosofia agostiniana poderíamos ser levados à seguinte indagação: para quê estudar a sensação se tudo já se resolve na iluminação divina? E se avançarmos um pouco mais outro problema se põe: num pensamento de cunho neoplatônico não bastaria ter uma visão de Deus para possuir o conhecimento do criado? O tema da sensação não estaria ligando Agostinho a um aristotelismo ou estoicismo que lhe são estranhos?

Em busca de tais respostas, investigamos, em nossa iniciação científica, uma obra de juventude de Agostinho, o De quantitate animae. Nela, a sensação aparece como questionamento de uma ontologia que considera que só possui relevância aquilo que é corporal. Diante disso, como postular uma alma incorporal? Mais ainda, como considerar a experiência da sensação já que o seu objeto é corporal? Nesse caso, a alma tem que ser também corpórea? Se ela não for corpórea deve ter um contato por meio de corpos? Mas como isso seria possível? E, um dos problemas mais instigantes e que muito nos mobilizou em nossa iniciação científica: a sensação é um conhecimento ou não?

Tanto no De quantitate animae quanto no De trinitate Agostinho precisa criticar uma filosofia corporalista; a estratégia para isso se dará na busca por demonstrar que a sensação é uma atividade da alma e não do corpo; evitando cair num espiritualismo ou solipsismo. Agostinho em nenhum momento procura uma solução fácil ao problema da sensação ${ }^{1}$.

Numa filosofia onde Deus e a alma são o que existe de mais importante, ${ }^{2}$ pensar na sensação parece ser irrelevante, ainda mais quando se concebe que a exterioridade, objeto da sensação, é aparentemente desprezada por Agostinho - vide o próprio De trinitate ${ }^{3}$. Entretanto é notável constatar que ao tratar do processo ascensional do homem em direção a Deus, o De quantitate animae, por exemplo, leva em consideração uma hierarquia ontológica no qual corpo e alma estão inseridos. Ora, se a sensação é uma atividade humana então parece que deve ser levada em consideração no processo ascensional, e de fato é, mas como isso se

${ }^{1}$ Eis o que nos diz Gilson (2006, p.119) sobre esse ponto: “A teoria da sensação é uma das que melhor permite discernir o que há de distinto na concepção agostiniana de homem. Sua aparente sutileza dissimula o pensamento mais simples e mais franco, pois em nenhum dos textos em que o problema é abordado - quer acidentalmente, quer em si mesmo - santo Agostinho descartou a linha, simultaneamente inflexível e sinuosa que escolheu".

${ }^{2}$ É clássico o mote Agostiniano "A. Deum et animam scire cupio. R. Nihilne plus? A. Nihil omnino" (Sol. I, ii, 7) ser considerado o eixo no qual se move toda a sua filosofia.

3 "Daí que o tempo inste comigo para procurar esta mesma trindade no homem interior, e para me encaminhar do homem animal e carnal, que se chama homem exterior, do qual falei tão longamente, para o homem interior. Aí esperamos nós poder encontrar a imagem de Deus" "unde tempus admonet hanc eandem trinitatem in interiore homine requirere atque ab isto de quo tamdiu locutus sum animali atque carnali qui exterior dicitur introrsus tendere. ubi speramus iuenire nos posse secundum trinitatem 'imaginem dei"” (trin. XI, xi, 18). Por que Agostinho falou "tão longamente" sobre o homem exterior se o que importa é o interior? 
dá? Como é justificado o seu papel nesse caso já a alma é de ordem incorpórea assim como Deus, mas o objeto da sensação é corpóreo, distinto de Deus?

Em parte, as respostas a tais problemas são dados no próprio De quantitate animae. As respostas, contudo, não alcançam a clareza que desejaríamos. Além disso, achamos viável continuar a investigação em outras obras de Agostinho, principalmente aquelas de maturidade. Dentre eles o De trinitate nos pareceu sobrepor-se as outras pelas razões que se seguem.

Em primeiro lugar, o De trinitate é uma obra prima, onde, se considerarmos que o conhecimento de Deus parece ser o objetivo principal da filosofia de Agostinho, então, seria numa obra que trata especificamente sobre Deus que devemos buscar o cerne de seu pensamento. Em segundo lugar, por ser uma obra de maturidade, é mais plausível que ela seja o lugar onde podemos encontrar em boa dose o pensamento mais acabado do Hiponense. E, em terceiro, e talvez mais importante para os nossos propósitos, Agostinho dedica quase um livro inteiro da obra ao problema da sensação. Mais que isso, tal problema é visto a partir da consideração trinitária que é o clímax da filosofia Agostiniana.

Entretanto, tais motivações, por mais nobres que sejam ainda estão inseridas numa preocupação histórico-genética que justifica o corpus e a estratégia de investigação, mas não abarcam o campo dos problemas filosóficos. As questões que realmente motivam a presente pesquisa tocam alguns problemas cruciais da filosofia antiga, problemas estes que inclusive se estenderam pela modernidade chegando à contemporaneidade.

De alguma forma esses mesmos problemas aparecem no De trinitate, mas a partir de outro viés, aquele das analogias trinitárias. ${ }^{4}$ Nesta obra, a sensação se insere dentro de uma compreensão onde as analogias são consideradas dentro de um processo ascensional para o superior, assim como no De quantitate animae, mas que é feito modo interiore. Esse ponto não deve ser considerado acessório. Nossa tese é a de que, apesar de não negar a corporeidade, Agostinho procura mostrar que ela não pode ser considerada em si mesma, pois nesse caso ela é apenas alteridade. Assim, a solução do hiponense será a de mobilizar os termos interior e exterior com o intuito de relativizar todos os elementos criados, inclusive os corpos, objetos da sensação, a partir da identidade com aquilo que lhe é referência, o Deus trino. Entretanto, é justamente por relativizar aquilo que é criado que o superior e o inferior

${ }^{4}$ As analogias trinitárias começam a ser tratadas a partir do livro VIII se estendendo até o livro XV. Geralmente esse bloco é considerado como a segunda parte do De trinitate onde Agostinho estaria fazendo um tratamento mais filosófico da questão da Trindade, tentando justificá-la a partir das criaturas, daquilo que nos é mais evidente, e não das Escrituras (ver sobre Isso GIOIA, 2009, p.275-297; HENDRICKX, in La trinite, 1997, p.58-76). Entretanto, já dos livros V a VII Agostinho procede a uma especulação lógico-filosófica de fôlego sobre os conceitos trinitários dogmáticos. 
não correm mais o risco de serem considerados elementos estanques dos quais poderíamos correr o risco de desprezar algum aspecto da realidade. Assim, considerar algo como inferior ou superior dependerá do modo como a alma, que se move no processo ascensional, relaciona-se com eles. Nesse sentido, a sensação também ganha uma relevância filosófica na medida em que é atividade anímica orientada e vista da maneira correta a partir do interior.

Além disso, nossa pesquisa também pretende mostrar que a sensação é uma atividade que unifica três aspectos de uma primeira tríade exterior, e, por isso, se identifica com a teoria agostiniana da inseparabilidade das operações trinitárias. Em nosso ponto de vista é esse o aspecto mais marcante da transição do pensamento Agostiniano entre o De quantitate animae e o De trinitate, já que a doutrina da inseparabiliter operari de Agostinho é o que permite mostrar a relevância da sensação enquanto atividade e operação onde aparecem ao mesmo tempo, em analogia com as operações das três pessoas divinas, os três elementos da chamada primeira trindade exterior. Para nós essa doutrina é o eixo que permite interpretar todas as imagens trinitárias, e, em especial, dar um status diferenciado à sensação.

É nessa exposição que também não poderíamos deixar de responder as questões colocadas acima: a sensação é conhecimento? Sendo uma atividade anímica, e a alma imortal, como podemos sentir os objetos corporais? Em relação à primeira das questões tentaremos mostrar que sim, a sensação apesar de em si mesma não ser conhecimento, contudo, por ser uma atividade da alma que é vontade racional também é acompanhada de conhecimento. Quanto à segunda, a mediação se dará por um complexo uso que a alma faz dos cinco órgãos dos sentidos animando-os para atuarem como mediadores entre a alma e os objetos.

Para concluir, defenderemos também que, em certa medida, é apenas por causa da sensação que se dá a possibilidade de fazer a transição da sensus para a cogitatio - elemento da segunda tríade exterior, e assim, por diante, para todas as outras atividades das outras tríades, até se chegar à máxima identidade possível entre Deus e a alma no interior intimo meo.

\section{A SENSAÇÃo CONSIDERAda a PARTIR da DISTINÇÃo ENTRE HOMEM INTERIOR E EXTERIOR NO DE TRINITATE}


Ninguém duvida que, assim como o homem interior é dotado de inteligência, assim o homem exterior é dotado dos sentidos do corpo (trin. XI, i, 1). ${ }^{5}$

Essas palavras abrem o livro XI do De trinitate mostrando uma distinção entre interior e exterior. Para compreender o tema da sensação nesta obra dois eixos teóricos de fundamental importância devem estar claramente definidos: homem exterior-interior e a ascensão interiorizante. $^{6}$

Já no trecho acima citado o homem exterior é caracterizado como aquele que é dotado dos sentidos do corpo. Como veremos a frente, tais sentidos estão relacionados à sensação, portanto, devendo essa ser considerada dentro dessa relação. Contudo, para esclarecer tais pontos resta compreender o que Agostinho está querendo dizer com homem exterior e interior e ascensão interiorizante.

Num primeiro momento parece que exterior e interior se apresentam como opostos. É o que parece dizer Agostinho ao procurar encontra uma espécie de fronteira entre ambos:

"Pois bem, vejamos agora onde se situa essa espécie de fronteira entre o homem exterior e o interior $[\ldots . .]^{\prime \prime}$.

O termo "fronteira" [confinium] poderia nos conduzir a pensar em uma divisão marcada e acentuada entre homem interior e homem exterior na qual, ao primeiro estaria relacionada à inteligência como uma faculdade ou característica do mesmo, enquanto ao segundo os sentidos como faculdade ou característica correspondente. Contudo, uma análise mais precisa nos mostra que confinium é justamente o ponto de contato entre duas regiões distintas. Dessa forma, postulamos de saída que os dois elementos estão inter-relacionados de modo mais dinâmico. Isso porque quando falamos em ascensão interiorizante o próprio termo "interiorizante", ao pressupor o conceito de interior, consequentemente exige a sua contraparte, o exterior; nesse caso, já entramos numa distinção que é feita claramente por Agostinho entre o homem interior e o exterior. A ideia é mostrar que a ascensão interiorizante é uma passagem do homem exterior para o interior.

Dessa feita, nessa primeira parte, tentaremos situar o par interior-exterior/exteriorinterior. Mostrar do que se trata e que estamos diante de dois aspectos mais dinâmicos que estanques.

\footnotetext{
5 “nemini dubium est sicut interiorem hominem intellegentia sic exteriorem sensu corporis praeditum".

${ }^{6}$ Ascensão interiorizante traduz o latino introrsum ascendere.

7 "age nunc uideamus ubi sit quase quoddam hominis exteriores interiorisque confinium" (trin. XII, i,
} 1). 


\title{
1.1.Interior e Exterior, Considerados a partir da Relação da Alma Humana com Deus.
}

Para demonstrar a nossa tese precisamos proceder a uma primeira aproximação do par conceitual interior-exterior. Vejamos o que nos diz Agostinho:

\begin{abstract}
Quando nós deixarmos de lado aquelas coisas que são exteriores aos homens e desejamos subir interiormente a partir das que partilhamos com os gados, antes de alcançarmos o conhecimento das realidades inteligíveis e supremas, que são sempiternas, vem ao nosso encontro o conhecimento racional das realidades temporais. ${ }^{8}$
\end{abstract}

É importante notar novamente essa constante: não subimos com o exterior, subimos interiormente [introrsum ascendere], pois é do interior que se deve partir. Nesse caso, do interior o homem deixa de lado o elemento exterior, o corpo, para se voltar às atividades anímicas que compartilhamos com os gados. ${ }^{9}$ Contudo, logo percebemos que, apesar do movimento ascensional depender da interioridade ele começa a partir da exterioridade; a primeira vista um paradoxo que procuraremos esclarecer adiante.

A partir de tais considerações, notamos então que apesar desse voltar-se para o interior pelo próprio interior deixar de lado as coisas que respeitam à exterioridade, isso não quer dizer que tal exterioridade não entre na consideração do movimento ascensional, ao que parece o texto apenas diz que há um ultrapassamento. O ultrapassamento tem a ver com a relativização dos dois: exterior e interior. Contudo, resta perguntar: qual o fundamento de tais afirmações? Como sustentá-las?

Quando consideramos a relação da alma humana em relação com Deus parece que o par interior-exterior tem o seu fundamento e ganha algumas precisões. Essa consideração está presente em Agostinho desde sua juventude, por exemplo, no De animae quantitate onde o único elemento que podemos identificar com Deus é a alma enquanto considerada como similis Deo, ou seja, semelhante a Deus. ${ }^{10}$

Nesta obra, depois de abordar a origem da alma no primeiro capítulo, se chega à conclusão de que sua origem é o próprio Deus. No segundo capítulo, ao questionar qual seria a natureza dessa alma, afirma-se que a mesma possui uma natureza semelhante a Deus.

8 "Relinquentibus itaque nobis ea quae exterioris sunt hominis et ab eis quae communia cum pecoribus habemus introrsum ascendere cupientibus, antequam ad cognitionem rerum intellegibilium atque summarum quae sempiternae sunt ueniremus, temporalium rerum cognitio rationalis occurrit" (trin. XII, xv, 25).

${ }^{9}$ No De animae quantitate, por exemplo, essas duas atividades que compartilhamos com os animais são respectivamente a animatio e a sensus.

${ }^{10}$ A partir do questionamento de Evódio: “o que é a alma?" Agostinho lhe responde: "me parece ser semelhante a Deus" “uidetur mihi esse similis Deo" (an. quant. I, ii, 3). 
Esse par de definições logo no começo da obra é importante, pois mostra quais são as intenções de Agostinho no tocante aos rumos que o diálogo tomará - já que, da identificação da alma com Deus, que pertence à ordem do incorpóreo, temos uma pista de sua natureza. Daí a consequência é a dedução de que, se ela tem origem em Deus, ela também pode ser semelhante a Deus, ou seja, também incorpórea. Esse pressuposto já pode fundamentar a incorporeidade da alma, pois a natureza de Deus não sendo sensível, mas espiritual, consequentemente estabelece que, em decorrência dessa semelhança da alma com Deus essa alma deve ter uma natureza incorporal. Essas considerações nos obrigam a fazer pensar na distinção entre a natureza de Deus e a natureza humana; no que ela consiste?

Analisando a epistola XVIII à Celestino, Novaes (2007, p.178) faz uma exposição de modo claro acerca da distinção entre Deus, alma e corpo, mostrando que os seres se distribuem hierarquicamente a partir da consideração da sua mutabilidade ou imutabilidade: as naturezas que mudam conforme o lugar e o tempo, ou seja, as naturezas corporais; e as que mudam apenas no tempo, as espirituais, como no caso da alma humana; por fim, a natureza que não muda nem conforme o tempo e nem conforme o lugar, a natureza divina, ou seja, Deus.

Entretanto, o mesmo Novaes aponta para mais uma divisão que pode decorrer da primeira, não mais em três partes, mas em duas, sendo que, de um lado estão as naturezas corpóreas e a alma, e do outro Deus. Tal divisão encontra seu fundamento na ideia de mutabilidade (Ibid), mas agora levada ao seu limite ontológico: as criaturas são mutáveis; o Criador é imutável.

Dessa exposição, o resultado aparenta ser decepcionante: Deus é distinto de todas as criaturas, inclusive a alma, por sua imutabilidade. Entretanto, considerando o problema com mais cuidado devemos nos lembrar de que a relação de natureza entre Deus e a alma é uma relação de semelhança e não de identidade; assim, da exposição hierárquica feita acima, podemos perceber certa identidade entre a natureza da alma e a natureza divina: ambas são incorporais. Entretanto, não se trata de identidade absoluta, pois existe uma distinção temporal entre ambas, causando assim a distinção de natureza - por isso o termo usado por Agostinho é o da semelhança. Nesse caso, os seres corporais seriam dessemelhantes a Deus? Não iremos além daquilo que Agostinho não se colocou; importa notar que, por este argumento a alma é colocada numa categoria superior à dos meros corpos, aproximando-se [similis] da natureza divina. 


\title{
1.2.Imago dei no homem interior e uestigium trinitatis, trinitatis effigiem ou aliquo modo simile no homem exterior
}

No De trinitate as coisas mudam de modo sutil, mas consideravelmente. Enquanto no De animae quantitate Deus está identificado com a alma, aqui a consideração com Deus já se dá também no homem exterior, ao menos no livro XI. Mas de fato o que é o homem exterior? Agostinho o define da seguinte forma:

\begin{abstract}
Pois bem, vejamos agora onde se situa essa espécie de fronteira entre o homem exterior e o interior. $\mathrm{O}$ que em nossa alma temos de comum com o gado diz-se corretamente pertencer ainda ao homem exterior. Pois, o homem exterior não é considerado somente corpo, mas sim quando se lhe acrescenta uma espécie de vida própria, que revigora o organismo físico e todos os sentidos de que está dotado para sentir as coisas exteriores. Quando as imagens desses objetos dos sentidos gravadas na memória são evocadas pela recordação, trata-se ainda de uma realidade que pertence ao homem exterior. $^{11}$
\end{abstract}

Observando o texto com cuidado, percebemos que o homem exterior se refere tanto ao corpo humano como às atividades da alma que fazem parte dos dois primeiros degraus ascensionais observados no De animae quantitate: a animatio, aqui relacionada à sua uita, e a sentienda ["as coisas" sentidas, ou seja, exteriores] relacionada com os sensus [sentidos]. Também comparecem, fazendo parte do homem exterior, a atividade da memória que guarda as imagens e as trazem à lembrança, habilidade que os animais também possuem. ${ }^{12}$

Uma análise mais detalhada de $X I, i, 1$ coloca-nos três termos ou expressões com os quais Agostinho refere-se ao homem exterior em sua relação com Deus: uestigium trinitatis, ou seja, uma marca de pegada; eodem modo sit imago dei, certa imagem de Deus; trinitatis effigiem, uma marca da trindade. Ao usar estes três termos ele parece evitar o uso de "imago dei" quando se refere ao homem exterior, isso por que ele irá reservá-lo especificamente ao homem interior: sobre esse ponto, em trin. XI, v, 8, se referindo à trindade exterior, ele diz que “... esta trindade (a exterior) ${ }^{13}$ não é a imagem de Deus" ${ }^{14}$, de onde surgirá mais uma

11 "age nunc uideamus ubi sit quasi quoddam hominis exterioris interiorisque confinium. quidquid enim habemus in animo commune cum pecore recte adhuc dicitur ad exteriorem hominem pertinere. non enim solum corpus homo exterior deputabitur sed adiuncta quadam uita sua qua compages corporis et omnes sensus uigenti quibus instructus est ad exteriora sentienda. quorum sensorum imagines infixae in memoria cum recordando reuisuntur res adhuc agitur ad exteriorem hominem pertinens " (trin XII, i,1)

${ }^{12}$ Adiante trataremos da memória também pertence ao homem interior, mas pode fazer parte do homem exterior. Nesse caso, temos um forte argumento para mostrar que a questão do homem exterior e interior não responde a algum elemento dicotômico ou compartimentos estanques no ser humano.

${ }^{13} \mathrm{O}$ parêntesis é meu.

14 “... non est ista trinitas imago dei”. 
expressão para se referir à relação entre o homem exterior e Deus, "aliquo modo simile est deo":

Certamente que não deve ser dita imagem de Deus tudo aquilo que nas criaturas é de algum modo semelhante a ele (aliquo modo simile est deo), mas apenas aquela imagem pela qual só ele é superior. Porque, expressão perfeita de Deus é aquela entre a qual e ele nenhuma natureza se interpõe. ${ }^{15}$

Em todo o parágrafo 8 Agostinho estabelecerá uma relação do homem exterior com as criaturas corpóreas, mas agora abandona o termo "effigies" substituindo-o por "aliquo modo simile est deo". No primeiro parágrafo, por sua vez os três termos parecem intercambiáveis, contudo, falar que o homem exterior "non quia et ipse eodem modo sit imago dei" nos dá uma ideia da proximidade e ao mesmo temo do afastamento do homem exterior em relação ao homem interior e o Deus Trindade.

No limite, todos os termos parecem revelar um esforço de compreensão do problema. Mais que isso, Agostinho parece precisar seu vocabulário já que effigies não aparece mais no decorrer da exposição do livro XI cedendo lugar a "similis", termo este que estabelece de forma mais clara a distinção entre aquilo que é semelhante [similis], e aquilo que é imagem [imago] de Deus. Imago dei será usado especificamente para o homem interior. Dessa feita, Agostinho coloca a exterioridade, no nível da semelhança, que também pode ser compreendida como uma espécie de imagem inferior [effigie] de Deus, ou seja, "uma figura da trindade" e não uma "imago dei" ou "imago trinitatis". Mas como dissemos acima, os termos parecem ser flutuantes, pois vimos que Agostinho parece não se conformar com a referência de "effigie" ao homem exterior, precisando-o com "aliquo modo simile".

\subsection{A Dinâmica Relacional entre Exterior e Interior}

Assim, não aparece no pensamento inicial de Agostinho a ligação entre Deus com a exterioridade seja ao nível de semelhança, seja ao nível de imagem, mais que isso, a própria alma é similis deo. Por sua vez, no De trinitate a semelhança é relacionada ao chamado "homem exterior", ou seja, ao homem na medida em que se aproxima das criaturas, principalmente consideradas em sua exterioridade, a exterioridade que se aproxima dos corpos. Entretanto, esse aspecto não deve ser considerado de modo estanque já que como

\footnotetext{
15 "non sane omne quod in creaturis aliquo modo simile est deo etiam eius imago dicenda est, sed illa sola qua superior ipse solus est. ea quippe de illo prorsus exprimitur inter quam et ipsum nulla interiecta natura est'. (trin. XI, v, 8).
} 
vimos acima; não deveríamos levar o termo confinium, ou seja, fronteira, entre o exterior e interior de um modo muito radical já que:

[...] o homem exterior não é considerado apenas corpo, mas também quando se lhe acrescenta uma espécie de vida própria, que revigora o organismo físico e todos os sentidos de que está dotado para sentir as coisas exteriores. Quando as imagens desses objetos dos sentidos gravadas na memória são evocadas pela recordação, trata-se ainda de uma realidade que pertence ao homem exterior. ${ }^{16}$

O texto é cristalino: "o homem exterior não é considerado apenas corpo". O que é então? É corpo, sim, mas não apenas: a vida anímica e a memória também se fazem presentes como parte do homem exterior; o limite do homem exterior está naquilo que ainda possuí alguma ligação com a exterioridade, neste caso, a imagem do objeto externo guardada na memória (tal imagem vem da exterioridade).

Deve-se notar que os animais possuem uma alma obviamente, mas uma alma que se volta apenas aos objetos externos. Ora, se pensarmos que o homem não possui duas almas, mas apenas uma, então podemos concluir que, enquanto se volta aos objetos externos essa alma possui uma dinâmica para a exterioridade. Por outro lado ao voltar-se às realidades incorporais possui uma dinâmica para a interioridade:

"Já na outra trindade, certamente interior a esta que reside nas coisas sensíveis e nos sentidos, mas que é concebida a partir dela, quando já não é o sentido do corpo que recebe a forma a partir de um corpo, mas é a visão do espírito que recebe a forma a partir da memória quando a imagem do corpo que sentimos no exterior se fixa na mesma memória". ${ }^{17}$

Não precisamos seguir o restante da exposição de Agostinho no parágrafo sobre as atividades da memória em relação ao que é exterior e interior; importante é saber que nessa exposição dois elementos são esclarecidos: em primeiro lugar, a interioridade é um elemento que é relativo ao que lhe é exterior, ou seja, a interioridade é dada na medida em que há um afastamento do exterior. Esse aspecto é marcado pela presença do sufixo ior que coloca o adjetivo desusado inter ou interus no comparativo, indicando não somente a interioridade,

16 “[...] non enim solum corpus homo exterior deputabitur sed adiuncta quadam uita sua qua compages corporis et omnes sensus uigenti quibus instructus est ad exteriora sentienda. quorum sensorum imagines infixae in memoria cum recordando reuisuntur res adhuc agitur ad exteriorem hominem pertinens ". (trin. XII, $\mathrm{i}, 1)$

17 "iam uero in alia trinitate interiore quidem quam est ista in sensibilibus et in sensibus sed tamen quae inde concepta est, cum iam non ex corpore sensus corporis sed ex memoria formatur acies animi cum in ipsa memoria species inhaeserit corporis quod forinsecus sensimus" (trin. XI, vii,11). 
mas algo mais interior visto em relação àquilo que lhe é mais próximo ou vizinho. Assim, o interior é algo que está em relação de proximidade e afastamento de outro algo. O mesmo se aplica a exterior, que é consideração relativa a partir da exterioridade. Dessa forma interior e exterior são posicionamentos baseados em determinada consideração que pode se dar a partir da exterioridade ou da interioridade. Em segundo lugar, a memória opera na progressiva interiorização na medida em que fixa a forma vista no ato da sensação e permite à visão interior ou pensamento [cogitatio] se voltar à mesma, assim, sendo parece existir uma valorização da relação interior-exterior que é posta no primeiro elemento, o interior.

Um pouco antes, esse aspecto pode ser visto também no parágrafo 6 do mesmo livro, onde Agostinho considera a atividade cogitativa (cogitatio) da visão interior (interna uisione) sobre os dados provindos da sensibilidade, mas que estão guardados na memória. Os elementos envolvidos na cogitatio são: a memória, visão interior e vontade. ${ }^{18}$ Todos estes fazem parte do homem interior:

[...] e o que é a atenção da vontade para unir o corpo visto e a visão, ${ }^{19}$ para que nisso se realize uma espécie de unidade dos três, embora a natureza deles seja diferente, isso mesmo é a atenção da vontade para associar a imagem do corpo que está na memória e a visão quando se pensa, ou seja, a forma que o olhar da alma captou ao voltar à memória, para que, também neste caso, se faça uma espécie de unidade a partir dos três, já não separados pela diferença de natureza, mas sendo os três de uma única e idêntica substância, porque tudo isto é interior e tudo isto é um só espírito. ${ }^{20}$

Nestes dois exemplos temos uma passagem da primeira trindade exterior para uma segunda trindade exterior, mas que já é mais interior à primeira. Os movimentos se dão a partir de determinado referencial, no caso aqui a alma, principalmente a memória que pertence às duas dimensões. ${ }^{21}$ Assim, posso falar em interioridade de determinados atributos da alma como os listados acima quando os comparamos com as atividades imediatamente sensitivas. Por outro lado, esses mesmos elementos aqui listados como pertencendo à

${ }^{18}$ A cogitatio será considerada no terceiro capítulo desse trabalho.

${ }^{19}$ Aqui Agostinho está fazendo referência à trindade exterior composta de vontade, imagem do objeto corporal visto, ou seja, a specie desse objeto, e a visão que é a specie no sentido da visão. Essa trindade está sendo comparada com a trindade interior.

20 "... et quod est intentio uoluntatis ad corpus uisum uisionemque copulandam ut fiat ibi quaedam unitas trium quamuis eorum sit diuersa natura, hoc est eadem uoluntatis intentio ad copulandam imaginem corporis quae inest in memoria et uisionem cogitantis, id est formam quam cepit acies animi rediens ad memoriam, ut fiat et hic quaedam unitas ex tribus non iam naturae diuersitate discretis sed unius eiusdemque substantiae quia hoc totum intus est et totum unus animus" (trin. XI, iv, 7). Os negritos são meus.

${ }^{21} \mathrm{O}$ próprio uso da expressão "interior intimo meo", quase introduzível, já indica que pode existir a consideração de um interior em relação a outro interior. Mais que isso, o processo parece indicar uma progressão ascendente onde o que foi "ultrapassado" se torna mais exterior àquilo que foi alcançado. 
exterioridade, quando relacionados com outras atividades da alma como a racionalidade que lida com os elementos temporais e a inteligência que lida com os elementos eternos, são considerados interiores, apesar de também lidarem com a exterioridade:

\begin{abstract}
Aquela nossa parte que se ocupa da atividade das coisas corpóreas e temporais, de tal modo que nos não é comum com o animal irracional, é, sem dúvida, racional, mas é como que derivada daquela substância racional da nossa mente pela qual nos aproximamos da verdade inteligível e imutável, e é destinada a cuidar e administrar as coisas inferiores. ${ }^{22}$
\end{abstract}

Estamos no livro XII para o qual, Agostinho no final do livro XI tinha prometido que trataria do homem interior:

Daí que o tempo inste comigo para procurar esta mesma trindade no homem interior. Inclinando-me interiormente partindo do homem animal e carnal, que se chama exterior, do qual falei tão longamente para [o interior]. ${ }^{23}$

Homem exterior e interior não são, portanto, dois tipos de homem, e nem Agostinho deseja estabelecer uma distinção marcada entre ambos; isso seria mesmo impossível dado o caráter comparativo e relativo de interior e exterior. Assim, o que Agostinho explicita é que se fixar no homem exterior ou interior refere-se a uma postura relacional, e, dada a exposição anterior em que mostramos tal relação entre Deus e o homem. Agora resta estudar qual a relação entre interior e exterior com a ontologia, ou seja, com os elementos da existência e até mesmo Deus. Tentaremos elucidar essas questões, contudo, antes de tudo, resta argumentar contra uma tentativa que, a partir da relação interior-exterior procura criar uma cisão na alma humana. Esse outro aspecto tentamos esclarecer abaixo.

\title{
1.4.Distinção entre Homem Interior e Exterior dentro da Unidade da Alma
}

Pensar em uma dicotomia parece ser enganoso. A existência de dois homens, um exterior e outro interior como unidades separadas ou mesmo duas unidades justapostas seria causar, de algum modo, uma cisão na unidade humana. $\mathrm{O}$ que parece existir no pensamento

\footnotetext{
22 "illud uero nostrum quod in actione corporalium atque temoralium tractandorum ita uersatur ut non sit nobis commune cum pecore rationale est quidem, sed ex illa rationali nostrae mentis substantia qua subhaeremus intellegibili atque incommutabili ueritate tamquam ductum et inferioribus tractandis gubernandisque deputatum est" (trin. XII, iii, 3).

23 "unde tempus admonet hanc eandem trinitatem in interiore homine requirere atque ab isto de quo tamdiu locutus sum animali atque carnali qui exterior dicitur introrsus tendere" (trin. XI, xi,18).
} 
de Agostinho é a possibilidade de movimento que se orienta, por assim dizer, ou para o exterior ou para o interior. Dessa feita, quando se volta para o exterior, temos uma ênfase posta na alteridade, o que faz Agostinho usar o termo "homem exterior". Por sua vez, quanto mais se aproxima da identidade, mais interior o movimento se torna. Nesse sentido se usa o termo "homem interior". Ora, qualquer desses movimentos deve ser compreendido como sendo feito pelo homem como um todo que é regido pela sua alma.

Essa tese recebe uma justificativa mais incisiva de Agostinho quando este, ao argumentar contra os maniqueus que afirmavam a existência de duas almas numa mesma natureza humana, defende existência de apenas uma alma humana que se desdobra em "partes":

\begin{abstract}
"Pois se trata muito melhor e mais fácil entender que se trata de dois gêneros de coisas boas, nenhum deles alheio a Deus, seu criador, e que uma única alma está afetada pelas diversas partes, inferior e superior, o que pode ser corretamente dito exterior e interior. Estes são dois gêneros do qual a pouco tratamos pelos nomes de sensíveis e inteligíveis, aos quais chamamos mais prontamente e familiarmente de carnais e espirituais". ${ }^{24}$
\end{abstract}

Apesar de nesse trecho ficar clara a unidade da alma, a classificação dos binômios: inferior-superior, sensíveis-inteligíveis ou carnais-espirituais em "partes" ou "gêneros" dentro da mesma alma parece de algum modo dicotomizá-la. Contudo, como nos esclarece Fujisaka "O vocabulário retirado da tradição filosófica ${ }^{25}$ permite expressar o 'exterior' como um gênero distinto do 'interior' sem naturalizar as partes da alma” (2014, p.180). Note-se bem "sem naturalizar as partes da alma". Ora, classificar partes da alma ou tratar dos seus gêneros ainda não é substancializá-los em naturezas distintas.

A tradição filosófica neoplatônica também se depara com o problema da existência de duas almas. Como isso teria acontecido? A nosso ver isso se deveria à absorção, por parte deste, da teoria estoica da sympatheia universal.

A doutrina da sympatheia universal postula que o universo é um todo organizado, comparado a um ser vivo. Segundo J. Moreau (1970, p. 17), essa é uma das teses fundamentais que caracterizam a cosmologia de Plotino. Isso se deve ao fato de que na época

24 "Possumus enim melius et multo expeditius intellegere duo genera bonarum rerum, quorum tamen neutrum ab auctore Deo sit alienum, unam animam ex diuersis afficere partibus, inferiore AC superiore, uel quod recte ita dici potest, exteriore atque interiore. Ista sunt duo genera, quae sensibilium et intelligibilium nomine paulo ante tractauimus, quae carnalia et spiritalia libentius et familiarius nos uocamus" (duab. an. XIII, 19). Tradução de Daniel Fugisaka.

${ }^{25}$ Plotino, que provavelmente, ao menos indiretamente, influenciou o pensamento de Agostinho fala em uma dupla vida (amphibioi) da alma (Enéadas IV, 8[6]4) mas que permanecem como partes de uma única hipóstase da alma. 
de Plotino estava em voga um estoicismo platonizante que vinha de Antioco de Ascalon, escolarca da Academia Platônica no século I d.C. Tal estoicismo platonizante professava um dogmatismo sincrético, proclamando um acordo fundamental entre as doutrinas platônica, aristotélica e estoica. É a partir dessa concepção, segundo Moreau, que Plotino produz sua filosofia (ibid., p.18-19), mas, enquanto os estoicos rejeitam toda a transcendência, pois para eles é somente na Alma imanente ao universo que eles vêm o princípio de sua organização (ibid., p.18), Plotino faz repousar acima dessa anima mundi o Intelecto Aristotélico e o Uno, ou Bem Inteligível de Platão, os dois últimos como primeiras hipóteses acima dessa Alma do Mundo.

Para Plotino a sympatheia não é mais interpretada como no estoicismo para o qual todas as coisas se interpenetram umas as outras, mas sim como uma comunidade de afeição entre todas as partes desse ser unificado ${ }^{26}$. Ainda segundo Moreau, (1970, p.19) "nesse caso, todas as partes estão perto, mesmo distantes por causa de sua similitude 27 , pois num "ser vivo [...] nenhuma parte está tão afastada localmente que não esteja próxima em virtude da simpatia natural que unifica o ser vivo." 28

Mas qual o que tudo isso tem a ver com a alma? Nesse caso, a Alma Universal Plotiniana, apesar de estar presente em todas as coisas numa sympatheia, não pode ter algo de corporal como no estoicismo; ela permeia os corpos, mas não é corpo ${ }^{29}$; a Alma é gerada por processão a partir da Inteligência, a segunda hipótese, que por sua vez decorre da primeira que é o Uno ${ }^{30}$.

O que interessa mostrar aqui não são os pormenores desse processo, mas que, nesse sentido, a Alma ainda é inteligível assim como O Uno e o Nous. O que acontece a partir daí é que apesar de uma parte sua permanecer no inteligível ${ }^{31}$, esta Alma ainda se dirige aos seres sensíveis para lhes dar vida ${ }^{32}$. Daí Parente (2005, p.123) conclui que: “O que interessa aqui apontar é que a alma universal, a terceira hipóstase, é alma em si mesma, transcendente e pura, intelectiva, antes de descer ao cosmos e assumir a forma de 'Alma do todo' em relação

26 “[...] la transcendance platonicienne est complètement éliminé dans la cosmologie stoïcienne, pour qui l'Univers est un organisme vivant, régi par une âme immanent, à l'exclusion de tout transcendance de l'Idée ou de l'Intellect" (MOREAU, J., p.39,40).

${ }^{27}$ Isso é importante para a consideração da sensação como participe do processo de ascensão em Agostinho como veremos mais a frente.

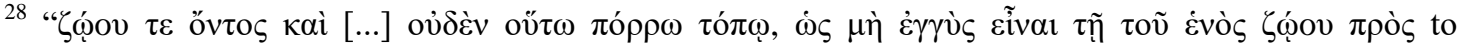

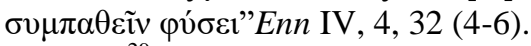

${ }_{29}$ Toda a tentativa de Plotino de evitar que na sensação exista uma ação da do objeto corpóreo sobre a alma (Enn III, 6 [26], 1) já indica a sua não corporeidade.

\footnotetext{
${ }^{30}$ Ver Enn V, 1, 6-7.

${ }^{31}$ Ibid V, 1, 10, 20 ss.

${ }^{32}$ Ibid III, 4, 4, 1 ss.
} 
direta com o corpo universal do mundo". Essa breve explicação é importante na medida em que esclarece a questão da alma individual que é o que nos interessa aqui, pois, ainda segundo Parente (ibid, p.146,147)

[...] Plotino, ao abordar o problema de um ponto de vista geral, tem grande tendência para afirmar o primado da universalidade e a teoria segundo a qual todas as almas singulares encontram na alma universal a sua unidade, nela se resgatando de sua dispersão. Esta teoria assenta, antes de mais, na consideração primária de que todas as almas encontram na alma universal o seu modelo e, portanto, a sua unificação a nível transcendente. A alma universal não é imanente às almas singulares, mas transcende-as, colocandose em referência a elas como um exemplar sobre o qual são modeladas [...] a alma individual é uma alma imagem da alma universal (IV, 9 [8], 1, 4, 15 ss), portanto em cada alma existe uma duplicidade da parte superior transcendente e da parte inferior (IV, 3 [27], 4, $30 \mathrm{ss}$ ) ${ }^{33}$

Uma parte superior, ligada ao transcendente, e outra inferior. À que está ligada esta última? A resposta à questão acerca do duplo aspecto da alma pode ser compreendida a partir de um texto onde Plotino procede a sua interpretação da alegoria da caverna:

Assim é dito com razão que a alma se encontra em uma tumba e em uma
caverna. Mas, apesar disso, retorna para o alto, convertendo-se ao ato do
intelecto [...], e pela memória contempla de uma nova maneira a essência das
coisas. Porque temos que convir que as almas possuem necessariamente uma
dupla vida (amphibioi): pois, por um lado, vivem em parte a vida inteligível;
por outro, vivem também em parte a vida desse mundo. ${ }^{34}$

A dupla vida, semelhante à concepção agostiniana identifica-se com as duas dimensões, a inferior-sensível e a superior-inteligível. É difícil negar que esteja aqui a origem da concepção agostiniana da alma que se "distende", por assim dizer, em duas partes.

\subsection{Ascensão Interiorizante como Característica Fundamental do Projeto Agostiniano}

Antes de prosseguir a investigação é necessário entender que a chamada "trindade exterior" é considerada dentro de um todo maior, o da ascensão interiorizante; em que os movimentos e passagens do exterior para o interior vão se aprofundando cada vez mais. Da trindade exterior deve-se partir para trindades mais interiores. É esse aspecto axial do

\footnotetext{
${ }^{33}$ Contra essa leitura e a favor de uma que defende que as almas são espécies de fragmentos dessa Alma universal ver BRÉHIER, 1961, p.59-64.

${ }^{34}$ Enn. IV, 8 [6] 4. A tradução utilizada aqui se encontra em FUGISAKA, 2014, p.181.
} 
pensamento de Agostinho que nos permite proceder a uma consideração mais precisa da relação interior-exterior.

No livro XII, por exemplo, Agostinho visa estabelecer uma precisão maior nesse movimento exterior-interior. É nessa precisão que se dará a análise da scientia. No começo desse livro, Agostinho fala de uma passagem que é concebida como elevação:

Mas, da mesma forma que o corpo se eleva naturalmente em direção àqueles que são os corpos mais elevados, isto é, os celestes, assim também a nossa alma, que é substância espiritual, se deve elevar, não pela arrogância do orgulho, mas pela piedade da justiça, até os corpos mais sublimes, na natureza espiritual. ${ }^{3}$

Parece existir um projeto de gradação no De trinitate. Gradação esta que obedece a certa ordem que vai do exterior para o interior. Entretanto, observemos que o texto expressa que é a alma, uma substância espiritual, que se eleva; estamos no mesmo registro do $D e$ animae quantitate. Talvez para compreender melhor esse problema e conseguir redimensionálo aqui no De trinitate seja instrutivo refletir como se processa essa elevação naquela primeira obra.

\subsubsection{Ascensão interiorizante do De animae quantitate}

No caso do De animae quantitate será proposta uma elevação que se faz por meio de um processo ascensional por escalonamento. Eis os passos do processo: animatio, sensus, ars, uirtus, tranquilitas, ingressio e contemplatio. ${ }^{36}$ A sensação, sensus, aparece como o segundo movimento [motus] da alma nesse processo ascensional. Movimento e processo ascensional; estes são dois termos que refletem a dinâmica da alma, in se e ex se, onde o voltar-se para si [in se] não anula um movimento para fora de si (ex), mas que não deixa a interioridade (se). Talvez esse movimento seja bem expresso nas palavras de Novaes:

\footnotetext{
35 "sed sicut corpus ad ea quae sunt excelsa corporum, id est ad caelestia, naturaliter erectum est, sic animus quae substantia spiritalis est ea quae sunt in spiritalibus excels erigendus est non elation superbiae sed pietate iustitiae". Vale aqui fazer algumas obsrvações acerca do uso dos termos anima e animus por Agostinho. Para este propósito seguiremos essencialmente a distinção feita por Gilson, para quem anima designa o princípio animador dos corpos considerando a função vital que neles exerce, desse modo, o homem tem uma anima assim como os animais. Quanto a animus é empregado preferencialmente para designar a alma do homem, ou seja, um princípio vital que é ao mesmo tempo substância racional da alma (nota 1 a. p.95). Em nosso trabalho traduziremos de modo geral tanto anima quanto animus por alma, sendo que o contexto dará o sentido do que se está falando. Se for necessário faremos as distinções necessárias para melhor entendimento da exposição.

36 "quaerimus quippe de animae potentia, et fieri potest ut haec ominia simul agat, sed id solum sibi agere uideatur quod agit cum difficultate, aut certe cum timore. agit enim hoc multo quam caetera attentior. ascendentibus igitur sursum uersus, primus actus docendi causa, dicatur animatio; secundus sensus; tertio ars; quartus, uirtus; quintus tranquillitas; sextus ingressio; septimus, contemplatio". (an. quant. I, xxxv, 79).
} 
O homem interior reúne em si as fases anteriores do caminho: de certo modo, no espírito o homem se apropria daquilo que aparece como exterior, e nessa medida o interioriza. Dizer que o homem "se compõe de espírito, de alma e de corpo" (exp. Prop. Rm LIII), significa dizer que ele pode aprender como seu aquilo que antes era apenas alteridade. Pois a reunião das três "naturezas" no homem faculta a experiência de cada uma delas como própria, e, na verdade, como dependente da alma humana. Tal é, nos parece, o sentido da minuciosa apresentação no De animae quantitate, de sete degraus ou "operações" ("actus") da alma, que progridem, ou ascendem da mera animação vegetativa do corpo até a contemplação de Deus (2007, p.198). ${ }^{37}$

Novaes se move no mesmo campo que Sciacca, para quem o processo ascensional em Agostinho leva em consideração as fases anteriores; nesse sentido diferiria do platonismo que vê as fases anteriores como graus a serem superados. ${ }^{38}$ Tal negação do homem exterior não tem lugar em Agostinho pelo fato de que o corpo, que faz parte da exterioridade é criação divina e possuí uma unidade com a alma como vimos. ${ }^{39}$

No processo ascensional existe uma passagem da animatio para a sensus. Em se tratando de animatio a progressão começa de corpore, para em seguida, passar ao sensus que per corpus ascende ao próximo grau; parece, nesse sentido, que existe um dinamismo ascensional que se funda justamente na passagem dos degraus do ser. A mesma ideia se

37 Madec (1994, p.138) vê nesses degraus a base para um dinamismo que permite o processo ascensional: “[...] ce sont les degrés de l'être qui fondent le dynamisme ascencionnel d'âme”.

38 "ne la jeraquía de las formas de actividad del alma, ninguna de ellas es considerada como um grado inferior del cual hay que separarse para ascender (como em Platón o em Plotino), sino que todas ellas son grados dentro de la espiritualidad, por lo cual la sensación es acto interior y aun la corporeidad es forma de espiritualidad. La jerarquización de las formas há sido hecha por Agustín de manera original y señala uma conquista de la filosofía: no se trata de una separación y devaluación del 'hombre exterior ${ }^{\text {, }}{ }^{38}$, porque en lo corpóreo se halla el alma que le da vida y especie; se trata, antes bien, de uma elevación de corpóreo a lo espiritual, al 'hombre interior', de modo que la supremacía de la mente no sea como la del amo sobre el esclavo o del superior que no reconece la positividad del inferior" (1954, p.14).

39 "Verdad es que, dado que alma y cuerpo forman uma unidad sustancial y el alma es vida del cuerpo mismo y es la que le da la especie, se puede hasta decir que corpóreo participa de esta superioridad y es la expresión de ella. Agustín no se opone a esta afirmación que, más que negar la superioridad del alma sobre el cuerpo, la confirma en el sentido de que el cuerpo y los sentidos resultan em el hombre expresiones de espiritualidad y de las funciones más altas del alma; pero lo son precisamente en cuantoel cuerpo y los sentidos se hallan sustancialmente unidos a uma esencia espiritual partícipe de la verdad y creada por Dios a su imagen" (SCCIACA, 1954, p.13,14). Ainda o mesmo autor, ao analisar o De moribus ecclesiae catholicae completa: "Efectivamente, precisamente em el escrito contra los maniqueos, combate la doctrina (de inspiración platónica) de que Dios de las tinieblas sea autor del cuerpo y el Dios de la luz autor del alma, y les contrapone la outra teoría (cristiana) de que Dios es el creador de la materia y del espíritu. Evidentemente Dios bueno no crea el mal; por tanto, la materia, por El creada no es el mal. Sobre la base de este principio, el rechazo de la doctrina que hace al cuerpo extrínseco al alma y hace de esta última uma substancia completa, condenada a vivir em un cuerpo como em uma cárcel y, sea como fuere, como em algo extraño a su naturaleza, es una consecuencia irrefutable. Sin decir que Dios (Sumo Bien), creador del alma y del cuerpo, no crea al alma superior solamente (como en Platón), sino que crea um hombre (Adán), o sea no uma substancia (alma) que se une a outra (cuerpo) no creada por él (unión ésta que no puede ser más que extrínseca y accidental), sino una sola sustancia, el hombre constans de alma y cuerpo; y la unión aquí no puede ser otra que intrínseca y sustancial. A este resultado conforme com ele principio de que el hombre há sido creado por Dios, Agustín llegó con el tiempo, a medida que iba sometiendo a crítica su platonismo" (p.11). 
encontra também em Conf. X, viii, 12 em que Agostinho trabalha no campo semântico e conceitual de ascendere: "E ultrapassarei, portanto, a força da minha natureza, ascendendo em graus até aquele que me fez" ${ }^{40}$ A força natural, ou vitalidade é um caminho na ascensão: "Per ipsam animam meam, ascendam ad illum Deum", assim a alma é superior ao corpo, mas em um corpo. O movimento ascensional deve transcender a uiam meam, que é a alma como princípio vital que ocupa e vivifica o corpo, assim é um ultrapassamento da alma pela própria alma (de corpore segundo a leitura do De animae quantitate). Ora, esse paradoxo só pode ser entendido na medida em que se pensa nas relações interior-exterior: a própria alma se ultrapassa na medida em que ultrapassa aspectos de sua atuação, mas, em ultima instância é a mesma alma que se ultrapassa, dessa forma os degraus anteriores não são excluídos na consideração posterior.

Ainda pensando nas Confissões percebemos que o movimento ascensional não se estagna no âmbito da vitalidade, pois nesse caso teríamos que reconhecer que a mula e o cavalo que não possuem intellectus também ascenderiam a Deus. $\mathrm{O}$ homem deve transcender a mera uis animantis, e partir para a uis sentiente por meio da sensus que é responsável pela visão, audição e todos os cinco sentidos. ${ }^{41}$ Apesar disso, Agostinho faz questão de lembrar, como tivemos ocasião de ver em consonância com o De animae quantitate, que esse âmbito ainda pertence aos animais. ${ }^{42}$

Ao estabelecer a distinção entre os homens e os animais, Agostinho argumentara que o fundamento da superioridade do homem em relação às bestae é estabelecido por Deus (Deus praeposuit) que dá aos homens a capacidade mental, racional e científica que faltam aos animais, ou seja, a sensação é considerada como algo inferior, à scientia. Contudo, e aqui está o mais importante, a distinção entre os graus e relação de superioridade ou inferioridade é dada pela referência Deus.

A clássica passagem de De libero arbitrio II, iii, 7 pode-nos esclarecer ainda mais essa questão. Nesse trecho, em um dos passos para a da famosa "prova" da existência de Deus, Agostinho, ao dissertar sobre a progressão esse, uiuere, intellegere estabelecerá um princípio hierárquico para fundamentar qual seria o superior entre esses três. Tal princípio reza que o

40 "Transibo ergo et istam naturae meae, gradibus ascendens ad eum, qui fecit me".

${ }^{41}$ Agostinho afirma que existe uma força (alma?) que não só vivifica, mas também sensibiliza o corpo, habilitando-o a ter sensações: "Est alia uis, non solum qua uiuifico sed etiam qua sensifico carnem meam, quam mihi fabricauit Dominus, iubens oculo, ut non audiat, et auri, ut non uideat, sed illi, per quem uideam, huic, per quam audiam, et propria singillatim ceteris sensibus sedibus suis et officiis suis: quae diuersa per eos ago unus ego animus." (Conf. X, vii, 11).

${ }^{42} \mathrm{Na}$ verdade esse elemento tanto aparece na discussão sobre a sensação como também posteriormente em I, xxxiii, 72 quando Agostinho está falando da sensação como um dos graus da alma: "sed haec rursus omnia posse animam etiam in bestiis nemo negat". 
superior, ou mais excelente entre eles, seria o ser que possuí as três propriedades: "quare non dubito id excellentius iudicare cui omnia tria insunt quam id cui uel unum desit". Como exemplo do princípio, Agostinho cita a pedra, o animal e o homem, sendo que, a pedra tem ser, mas não vive e nem pensa, o animal tem ser e vida, mas não pensa, enquanto o homem não somente tem ser e vida, mas também pensa. Nesse caso, a superioridade aqui pertence ao ser pensante: “... qui autem intellegit, eum et esse et uiuere certissimum est”. Transpondo o princípio e os exemplos para o De quantitate animae, podemos dizer que o cadáver tem ser (esse), pois existe, os animais, que possuem sensação, possuem tanto o ser quanto o viver (uiuere), e os homens ultrapassam os dois, tanto o cadáver, um corpo que não tem vida, quanto os animais, que tem sensação. O homem, por sua vez, tem o ser, a sensação (identificada com os seres vivos), e o pensamento.

Essa leitura do De animae quantitate a partir do De libero arbitrio é instrutiva na medida em que mostra que o processo ascensional é possibilitado por uma hierarquia, mesmo que nas distintas obras, os problemas sejam abordados a partir de referenciais distintos. Além disso, percebemos que no homem que possui esse, uiuere e intellegere estão presentes elementos que não estão presentes nos seres inanimados e animados. Ora, justamente percebemos que o homem que possui intelligentia reúne a uita também que, como vimos acima, pertence aos animais. Assim, fica provado mais uma vez que o homem não ultrapassa os estágios ascensionais - ainda que o texto não fale claramente de ascensão, o principio que reúne no homem a consideração de todos os aspectos de sua vivência, estão presentes aqui também.

\subsubsection{Ascensão Interiorizante no De trinitate}

Análogo ao processo de elevação do De quantitate animae também no De trinitate podemos perceber um processo de elevação ${ }^{43}$ que parte da alma. Começando no livro XI já

${ }^{43}$ Esse processo de elevação, tanto no De quantitate animae quanto no De trinitate possuí o caráter de um exercício intelectual de elevação. Eis o que nos diz Moingt sobre isso: "Dans les premiers dialogues, l'exercitatio animi avait sourtout pour but de purifier et d'entraîner l'esprit. Héritier de la tradition platonicienne, Augustin sait qu'il est difficile de s'élever à la contemplation des veritès spirituelles, si l'on ne s'y prépare par une sorte de discipline de l'attention et d'ascétisme intelectuel [...] Mais, dans le De trinitate, il y a plus que cela. Cette exercitatio n'a plus seleument cet aspect de jeu serieux et d'exercice gratuit. Comme l'a note Marrou, elle 
percebemos uma alma que, na medida em que a mesma se volta para o que lhe é exterior, e depois, quando se volta para o interior, aquilo que lhe é exterior é reconsiderado a partir da cogitatio, que, ao que parece, ainda não faz parte da racionalidade científica, mas que, no entanto, é mais interior que os sentidos que pertencem ao homem exterior. Quando a alma se volta para a sua interioridade, daí se move para a consideração da scientia e continua até se chegar à sabedoria pela intelectualidade. Essa gradação é a passagem da consideração das temporalium rerum cognitio rationalis para as intellectualis cognitio aeternarum rerum (trin, XII, xv, 25).

Agostinho afirma que a cognição intelectual das coisas eternas é preferível à cognição racional das coisas temporais, pois ao deixar de lado o que concerne às coisas exteriores o homem "sobe interiormente" [introrsum ascendere], primeiro pela consideração daquilo que partilhamos com os pecora (bois - que estão no simples registro da vida sensitiva) para o conhecimento racional das coisas temporais, para daí alcançar o conhecimento das realidades inteligíveis e supremas, ou seja, a sabedoria, analisada no livro XIII.

De todas essas considerações parece existir um projeto ascensional que se manifesta no processo de interiorização exterior-interior que parte da sensus (sensação) para a scientia (ciência), e da scientia como conhecimento racional das coisas temporais, para a sapientia, o conhecimento intelectual das coisas eternas. Ora, se a passagem do homem exterior para interior se dá também por meio da consideração da sensação, logo, é de se supor que a atividade sensitiva possua relevância filosófica.

Em De trinitate o processo ascensional culmina na contemplação do elemento puramente incorporal e imaterial que é Deus. Desse dado é relevante se perguntar por que não contemplamos essa Verdade diretamente ao invés de ter que passar por um processo ascensional como o que vem sendo explicitado? Em outras palavras: por que a um processo ascensional? No começo do livro XI Agostinho já nos fornece algumas pistas que podem elucidar o caminho a ser percorrido em busca da resposta ao problema.

\subsection{A Condição de Presente como Justificativa para a consideração da ascensão interiorizante a partir do exterior}

est incorporée à la recherche et devient une voie d'accès et de progrès dans la découverte de la véritable 'image de Dieu" (1997, p.612-613). Para mais considerações a esse respeito ver MARROU, Henri-Irénée. Saint Augustin et la fin de la culture antique. Paris: Boccard, 1938. p.299ss. 
Existe uma razão por que o homem se eleva do exterior para o interior ao invés de se elevar do próprio interior para o mais interior, ou não contempla diretamente a verdade. Qual seria ela?

Para entender melhor este aspecto em primeiro lugar é necessário ter em mente que no pensamento Agostiniano o homem exterior está ligado à corrupção:

Portanto, procuremos, na medida das nossas possibilidades, uma imagem da Trindade naquele que se corrompe. ${ }^{44}$

A resposta parece ser que a corrupção se relaciona com aquilo que é mortal e carnal:

[...] pela própria ordem de nossa condição, pela qual nos tornamos mortais e carnais, lidamos com as coisas visíveis mais facilmente e como que mais familiarmente do que com as inteligíveis. ${ }^{45}$

Certamente a ordem de nossa condição atual [ordine conditionis nostrae] faz referência à queda do homem: agora, como homens mortais e carnais, em consequência do pecado $^{46}$ lidamos com as coisas visíveis [uisibilia] mais facilmente do que com os inteligíveis [intellegibilia], enquanto que, antes da queda tínhamos mais facilidade com os inteligíveis. ${ }^{47}$ Pertence às coisas visíveis [uisibilia] ou corpos [corpora] a incerteza = "incerto corporum", e, tal incerteza, por sua vez, é tida como uma "infirmitatem" enfermidade. ${ }^{48}$ $\mathrm{XI}, \mathrm{i}, 1)$

44 “in hoc ergo qui corrompitur quaeremus quemadmodum possumus quandam trinitatis effigiem" (trin.

45 "illo ipso ordine conditionis nostrae quo mortales atque carnales effecti sumus facilius et quase familiarius uisibilia quam intellegibilia pertractamus" trin. XI, i, 1.

${ }^{46}$ Para Agostinho, dentre todas as consequências do pecado original, a principal é a escravidão: uma carnalidade no espírito (mente carnalis), quando ao invés, antes do pecado ele vivia uma espiritualidade na carne (carne spiritalis), portanto, ser escravo é estar dominado pela exterioridade (ciu. XIV, xiii, 1).

${ }^{47}$ No De anime quantitate, Agostinho mostra que não temos capacidade de lidar diretamente com os inteligíveis sem um exercício de purificação da mente. Entretanto, enquanto lá Agostinho mostra essa necessidade fazendo referência ao fato de que o homem está na caverna e, portanto, não consegue se voltar ao inteligíveis diretamente tendo que fazer a conuersio por meio das artes (ver HADOT, Ilsetraut. Arts libéraux et philosophiedans le pensée antique: contribution à l'histoire de l'éducation et de la culture dansl'antiquité. Paris: Librairie philosophique J. Vrin, 2005), aqui, no De trinitate, estamos em outro registro: é a queda do homem que o impede de contemplar diretamente tais inteligíveis. O vocabulário da conuersio dá lugar àquele da ascencio. Isso não quer dizer que ambas as informações sejam contraditórias. Quando pensarmos novamente na noção de exercício filosófico, podemos concluir que, longe de estarmos diante de uma contradição, estamos apenas em momentos distintos, onde a necessidade da investigação e os problemas levantados possibilitam soluções distintas para um mesmo problema. O que há, na verdade, é um refinamento cada vez maior das respostas que sempre serão provisórias.

${ }^{48}$ Sobre essa questão do homem exterior ser tocado pelo erro e pelo engano dos sentidos, e do habitus ligado à sensibilidade talvez sejam esclarecedoras as palavras de Bermon, para quem, "La perception sensible est cependant l'opération que l'esprit a le plus de mal à comprendre adéquatement, du fait précisément qu'elle est à origene de tous ses erreurs [...] Em dépit cette difficulté, l'étude de la perception sensible est fondementalement em accord avec la 'pedagogie' qu'Augustin met em oeuvre dans la Trinité, puisque elle prépare à mieux discerner la nature de l'esprit lui-même et, de ce fait, celle de Dieu [...] Augustin fait de l'analyse de la 
Certamente as consequências do pecado original levaram o homem a buscar a união com as imagens corporais, o que é negativo, pois o impede de prosseguir para a interioridade na medida em que tende a fixar-se nos corpos (trin. XI, iii, 6). ${ }^{49}$ Essa união é chamada de concupiscência [cupiditas] que, no pensamento de Agostinho, é tida como "o amor pelas coisas passageiras" ${ }^{50}$, ou seja, corruptíveis. O problema então parece estar menos em o homem possuir um corpo e ter sensações, do que dar a ao corpo e à sensação um lugar e função que não são aquelas para o qual foram projetados. Em outras palavras, o corpo não é mal ou uma prisão da alma, a sensação não é ruim em si mesma, pois o corpo foi criado pela vontade de Deus, ou seja, Deus quis criá-lo, e, nesse sentido é algo bom.

Contudo, para Agostinho, o corpo deve estar sob o domínio da alma. Assim sendo, ao invés de $\operatorname{amar}^{51}$ as coisas exteriores e passageiras, “com louvável vontade/amor" [laudabilem uoluntatem], deve dar a elas, um sentido útil [utile]. ${ }^{52}$ É possível que esse dever de um sentido útil seja o modo como a sensação tinha o seu lugar antes da queda. Mas aí a pergunta: o que significa considerar a sensação e a exterioridade utilmente? Para Bubacz, por exemplo, isso se dá na medida em que o homem, voltando-se para os dados fornecidos aos sentidos, faz uso desses dados para formar um conjunto consistente de crenças que estruturam experiências anteriores e moldam as futuras. Isso mostraria que as experiências possuem uma utilidade. ${ }^{53}$ Se isto de fato é assim, poderíamos afirmar que temos nesse ponto, uma primeira justificação para afirmarmos a importância da sensação em si mesma.

perception sensible del point de départ de la recherche que doit mener l'esprit à la connaissance de soi et à celle de Dieu" (2001, p.239).

49 "sed anima rationalis deformiter uiuit cum secundum trinitatem exterioris hominis uiuit, id est cum ad ea quae forinsecus sensum corporis formant non laudabilem uoluntatem qua haec ad utile aliquid referat, sed turpem cupiditatem qua his inhaerescat accomodat".

50 "nihil aliud est cupiditas, nisi amor rerum transeuntium [...]" diu. quaest. 83, XXXIII.

${ }^{51}$ Tal amor pelas coisas passageiras, pode ser considerado como a vontade que se volta às coisas passageiras, já que, no pensamento de Agostinho, em geral, amor e vontade se identificam. No próprio $D e$ trinitate Agostinho afirma que "[...] a nossa vontade, ou amor, ou dileção, que é a vontade em todo seu poder" "[...] uoluntatem nostram, uel amorem seu dilectionem quae ualentior est uoluntas" (XII, xxi, 41).

${ }^{52}$ No pensamento Agostiniano todo ser criado possui uma utilidade e tal utilidade é determinada por causa de seu fim. Essa questão da utlidade levanta a temática do uti e frui, recorrente em Agostinho. Para Gilson (2006, p.315), "Fruir é fixar sua vontade numa coisa por amor a essa coisa. Usar é servir-se de uma coisa como um meio para se obter outra" (GILSON, 2006, p. 315). Eis sobre isso as próprias palavras de Agostinho: "Frui enim est amore alicui rei inhaerere propter seipsam. uti autem, quod in usum uenerit ad id quod amas obtinendum referre, si tamen amandum est. nam usus illicutus, abusus potius uel abusio nominandus est" (De doct. christ. I, iv, 4). Em última instância apenas Deus deve ser fruído, pois todos os outros bens que derivam dele subordinam-se a Ele como fim. Percebamos como o frui determina como sobordinado à ele o uti. O corpo é útil à alma.

53 “Augustine thinks perception is useful, and Augustine thinks that the body's messages provide cues to the spiritual vision for the generation of images. The consistent set of beliefs that structure previous experiences and mold future experiences results from this utility and the physical element in experience. So, there is a continuous test for the hypothesis about the world that is formed by the spiritual vision. This test is, basically, one of utility" (BUBACZ, 1981, p.116.117). 
Mas, além disse elemento útil, há mais um modo positivo de se considerar a sensação e a exterioridade em outro momento deste livro quando Agostinho faz referência aos cânticos dos degraus.

Agostinho faz essa referência ao cântico dos degraus quando da análise da vontade de ver. Ou seja, a vontade considerada num registro ainda muito simples. Não o objeto da vontade que é o fim do homem, ou seja, o seu objetivo mais elevado que é a busca pela felicidade (beatitudo), ${ }^{54}$ mas a vontade de ver. Nesse caso, toda vontade tem um fim. No caso da vontade humana em geral (e como um todo), esse fim é a felicidade, enquanto o fim da vontade de ver é ter a visão, assim, para cada objeto ao qual a vontade se dirige para ver se existe um objeto a ser visto.

Numa filosofia como a de Agostinho onde a ordem é o que determina todas as coisas inclusive a moralidade, ${ }^{55}$ então, se a vontade de "ver" dirige-se ao fim bom, essa vontade será reta, se o fim é mau, a vontade será má.

Acreditamos que a presença aqui da "vontade de ver" não é um dado qualquer. Estamos no livro XI onde Agostinho está tratando da sensação a partir do sentido da visão. A visão humana deve ser direcionada. O homem se fixará nos objetos corporais se afastando de Deus, ou essa sensação será ocasião para reflexão filosófica que levará à ascensão interiorizante dando-lhe um status e relevância superior?

Se as vontades forem retas elas ajudam necessariamente no caminho da ascensão ${ }^{56}$. A vontade de ver deve estar orientada. Aqui estamos no campo conceitual da ascensio que, neste parágrafo se expressa a partir da mobilização da temática escriturística dos cânticos dos degraus. Mas o que são tais cânticos?

Em uma nota explicativa a esse ponto José Maria da Silva Rosa nos fornece algumas informações que podem ser valiosas. Segundo ele:

${ }^{54}$ A beatitudo no pensamento Agostiniano é identificada com a fruição de Deus, isso por que, para ele o objetivo da busca filosófica é a posse da Sabedoria que daria ao homem a verdadeira felicidade, ou seja a beatitude, ou vida feliz, nas palavras de Gilson, "um bem cuja posse satisfaz todo desejo e, por consequência, confere a paz" (2006, p.17). Esse bem, obviamente não pode ser identificado com qualquer coisa temporal na medida em que tais coisas podem vir a nos faltar e assim nos tirar do estado de fruição e paz e nos colocar num estado de medo que seria incompatível com a verdadeira felicidade. Ainda segundo Gilson, “[...] somente Deus é permanente e independente de todo o resto, pois apenas ele é eterno. Aquele que tem Deus é, portanto, o único que teria a felicidade" (idem, p.19). Ver De beata uita I, ii, 10: "Ergo nullo modo dubitamos, si quis beatus esse statuit, id eum sibi comparare debere quod semper manet, nec ulla saeuiente fortuna eripi potest [...] Deus, inquam, uobis aeternus et semper manens uidetur? [...] Deum igitur, inquam, qui habet, beatus est,".

${ }_{55}$ Para isso ver: BOUTON-TOUBOULIC, Anne-Isabelle. L'ordre caché: la notion d'ordre chez saint Augustin. Paris: Brepols. (Institut d'Études Augustiniennes), 2004.

56 "E, por isso, a ligação das retas vontades é uma espécie de caminho dos que sobem para a bemaventurança" "et ideo rectarum uoluntatum conexio iter est quoddam ascendentium ad beatitudinem" trin. XI, vi, 10. 
Cântico dos degraus é o nome que se dá aos salmos 119 a 133 que também são chamados de "cânticos das subidas" (ou ainda "cânticos dos peregrinos", "cânticos de romagem") porque eram entoados pelos judeus nas suas peregrinações (aliyah) a Jerusalém (na Páscoa, no Pentecoste e na Festa dos Tabernáculos), quer durante as diferentes etapas da viagem, quer à medida que iam subindo (mealah) cada um dos quinze degraus da escada (um salmo em cada degrau) que, no Templo, subia o Pátio das mulheres para o Pátio dos homens. Segundo a Mishnah (Middot 2, 5), os "cânticos dos degraus" eram cânticos processionais dos Levitas, à medida que iam subindo cada degrau até a "Porta do Cântico". "Subidas" poderia indicar outrossim, e simultaneamente, o tom de voz ascendente ("cântico gradual": em crescendo) com que deviam ser cantados. ${ }^{57}$

Esta ascensão ao templo de Jerusalém, de átrio em átrio, pode significar justamente a passagem do homem da exterioridade para a interioridade na qual a própria sensação visual já está num nível de interioridade, e daí cada vez para mais perto de Deus se percebe a identidade a partir da orientação divina. Assim, sob tais considerações, ambas, a exterioridade corpórea, e, por conseguinte, a sensação, são recuperadas na filosofia Agostiniana como parte do processo de ascensão necessário para o conhecimento das realidades espirituais. É isso que nos esclarece este longo trecho que se encontra no início do livro XII, mas que faço questão de citar na íntegra devido à sua importância para nossa investigação:

Quando as imagens desses objetos dos sentidos gravadas na memória são evocadas pela recordação, trata-se ainda de uma coisa que pertence ao homem exterior. E, em tudo isto, distamos dos gados apenas porque pela figura do corpo andamos eretos e não curvados, nesta diferença alerta-nos aquele que nos criou para não sermos, na melhor parte de nós, isto é, no espírito $^{58}$, semelhantes aos animais irracionais, dos quais nos distanciamos pela posição ereta do corpo. Não para que projetemos o espírito naquilo que há de mais sublime nos corpos. Buscar neles o repouso da vontade é rebaixar o espírito. Mas, da mesma forma que o corpo se eleva naturalmente em direção àqueles que são os corpos mais elevados, isto é, os celestes, assim também o nosso espírito, que é substância espiritual, se deve elevar, não pela arrogância do orgulho, mas pela piedade da justiça, até aos corpos mais sublimes, na natureza espiritual. ${ }^{59}$

Santo.

${ }^{57}$ Ver nota 16 na tradução portuguesa do De trinitate feita sob a coordenação de Arnaldo do Espírito

${ }^{58}$ Aqui traduzimos animus por espírito, pois o contexto pede uma distinção entre o homem e o animal. Se ambos possuem anima, logo, a anima do homem é superior porquê animus.

59 "quorum sensorum imagines infixae in memoria cum recordando reuisuntur res adhuc agitur ad exteriorem hominem pertinens. Atque in his omnibus non distamus a pecore nisi quod figura corporis non proni sed erecti sumus. Qua in re admonemur ad eo qui nos fecit e meliore nostri parte, id est animo, similis pecoribus simus a quibus corporis erectione distamus. Non ut in ea quae sublimia sunt in corporibus animum proiciamus. Nam uel in talibus quietem uoluntatis appetere prosternere est animum. Sed sicut corpus ad ea quae sunt excelsa corporum, id est ad caelestia, naturaliter erectum est, sic animus quae substantia spiritalis excelsa erigendus est non elatione superbiae sed pietate iustitiae" trin. XII, I, 1. 
Fixar-se mesmo naquilo que é mais sublime nos corpos é rebaixar o espírito. Esse rebaixamento está associado à busca pelo repouso da vontade nas coisas corpóreas. Devemos nos lembrar de que, para Agostinho, o repouso da vontade só se dará em Deus, ${ }^{60}$ enquanto que o repouso da vontade nas coisas corpóreas está associado à concupiscência. Ora, o espírito (anima) deve se elevar à natureza espiritual, o que pressupõe uma passagem do corporalsensível para o incorpóreo-inteligível; repousar nas coisas corporais que são objeto de consideração da sensibilidade é rejeitar ascender para o superior e se voltar para aquilo que lhe é exterior e inferior.

Contudo, afirmar que o repouso da vontade não pode estar nas coisas sensíveis não significa necessariamente que devamos deixá-las totalmente de lado. A questão não é simplesmente superar as coisas sensíveis, mas olhá-las, vê-las, reconsiderá-las a partir da orientação correta. Ao fazer isso, a passagem pelo sensível é pedagógica e necessária ${ }^{61}$, como já tivemos ocasião de ver, principalmente depois que pela queda o homem perdeu a unidade. Ora, só o termo "passagem", já mostra que deve existir um caminho a ser percorrido, e esse caminho deve contemplar o homem exterior e sensível, mesmo que esse seja apenas o passo inicial a ser dado. Contudo, nesse caminho não entra em consideração a concupiscentia. A sensação só pode ser realmente objeto de consideração pelo homem interior na introrsum ascendere quando esse homem deixa de lado a fixação nas realidades sensíveis. Agora, afastado da concupiscentia a alma pode se voltar para o fenômeno da sensação como ocasião reflexiva. Agora a sensação é objeto de ascensão.

60 "fecisti nos ad te et inquietum est cor nostrum, donec requiescat in te" Conf. I, i, 1.

61 Esse aspecto fica mais claro quando percebemos que, ao pensar na estrutura do De trinitate, Agostinho segue um plano de exposição que é interrompido no livro XI para consideração das trindades exteriores. Essa quebra na exposição faz parte da estratégia Agostiniana. Para entender melhor vejamos uma breve estrutura como esboço provisório:

$1^{\mathrm{a}}$. Parte: I-IV - Exposição dogmática.

$2^{\mathrm{a}}$. Parte: V-XV - Exposição filosófica

a. V-VII - Esclarecimento da terminologia trinitária por meio dos conceitos filosóficos.

b. VIII-XV - descobrir na vida-alma humana analogias que permitam representar e esclarecer o mistério da vida íntima de Deus. transição.

O livro VIII é um resumo dos livros anteriores e apresentação dos livros que seguem. Livro de

Livro IX - espírito humano dotado de conhecimento e amor como uma imagem da trindade.

Livro X - "euidentior trinitas" (trindade mais evidente): "memória (aqui como lembrança espiritual, conhecimento de si), inteligência e vontade".

Livro XI - “interrupção” da exposição para proceder à análise das trindades exteriores.

Não parece ser muito ousado pensar que a iterrupção reflete o modo com que conhecemos as coisas, principalmente, a Trindade divina. No De trinitate Agostinho parece querer mostrar que a ascenção interiorizante não se dá de modo tranquilo como nos graus ascensionais do De animae quantitate. Tomado pela ideia de pecado original, Agostinho pretende mostrar que a investigação do mistério trinitário esbarra em dificuldades. 
Assim, parece ficar aqui justificada a necessidade de uma passagem pelo homem exterior no processo ascensional. Ora, o modo do homem exterior claramente tem a ver com a exterioridade, logo, para entrar em contato com o mundo exterior, o homem se vale dos cinco sentidos, em última instância o homem exterior é, essencialmente, composto de sentidos:

Portanto, é pelos sentidos do corpo, de que o homem exterior é dotado, que sente os corpos, e esses sentidos, como facilmente se percebe, são cinco: vista, ouvido, olfato, gosto e tato. ${ }^{62}$

Dessa feita, o próximo passo é ver como se dá o processo de sensação no homem exterior e ver como a análise da sensação permitirá o aprofundamento da compreensão da progressão interior como progressão para a identidade.

Também pudemos observar como no De trinitate o processo de análise da sensação se dá num registro distinto de uma obra de juventude como o De animae quantitate, pois, enquanto nesta última a sensação visava mostrar a incorporeidade da alma, o De trinitate visa proporcionar uma compreensão do homem exterior para daí conseguir, numa certa identificação com aquele que lhe é semelhante, fazer uma passagem ascensional interiorizante; a incorporeidade da alma também comparece aqui, entretanto, resta ver com que função.

62 "sensu igitur corporis exterior homo praeditus sentit corpora, et iste sensus quod facile aduertitur quinque pertitus est, uidendo, audiendo, olfaciendo, gustando, tangendo" (trin. XI, i, 1). 


\section{A RELEVÂNCIA FILOSÓFICA DA SENSAÇÃo A PARTIR DA ASCENSÃO INTERIORIZANTE}

Apenas fizemos referências esparsas no primeiro capítulo por razões de exposição, contudo, é importante ter em mente a dimensão da expressão "ascensão interiorizante" [introrsum ascendere].

A ascensão é uma imagem da subida que se faz ao interior humano, mas que, como tentamos provar, parte do exterior. Por outro lado, ao mesmo tempo em que a ascensão parte deste exterior ela é feita modo interiore, ou seja, é a alma considerada em sua identidade una o motus corporis que permite ao homem começar a sua busca pelo Deus Trindade. Se as coisas são realmente assim, aparentemente estamos diante de um paradoxo: onde realmente a ascensão começa? Fora ou dentro? Se pensarmos no lugar que a sensação tem dentro desse processo admitindo que a ascensão comece pelo que está fora, mais exterior a alma em sua identidade, poderíamos ser levados a adotar o aparente senso comum e pensar que ela seja uma atividade corpórea, ou dos sentidos [sensus], ou dos corpos [corpus] mais ligados a essa exterioridade, mas que agem sobre esses mesmos sentidos. Contudo, como frisamos na introdução do presente trabalho, Agostinho escolherá outra via, colocando na atividade anímica a responsabilidade pela sensação, ${ }^{63}$ assim temos a ascensão feita de modo interior [modo interiore].

Diante dessa escolha o esforço do bispo de Hipona será argumentar contra uma filosofia corpórea que está presente principalmente no estoicismo; nesse segundo capítulo mostraremos então como é importante estabelecer a incorporeidade da alma e que a própria alma é responsável pela sensação, garantindo que, de alguma forma, a identidade com o divino seja preservada em todo o processo ascensional, inclusive no ato de sensação; este já revela, aliquo modo, certa imagem da Trindade. Assim, as imagens trinitárias no homem exterior e a incorporeidade da alma serão os elementos privilegiados para a compreensão da sensação, ambos dando-lhe relevância filosófica.

\subsection{As Imagens Trinitárias na Primeira Trindade Exterior}

No livro 11 Agostinho postula duas trindades exteriores. Segundo McDonalds (2012, p.243), as trindades do livro XI preparam para a compreensão da imagem mais adequada da

\footnotetext{
63 "atque in his cum sensus non procedat ex corpore illo quod uidetur sede ex corpore sentientis animantis" (trin. XI, ii, 3). Esse ponto será melhor desenvolvido na exposição do texto.
} 
trindade divina que é a de memória, compreensão e vontade. Agostinho identifica duas trindades no livro $\mathrm{XI}^{64}$. Cada modelo trinitário necessita possuir as seguintes características:

a. Cada trindade possui três membros distintos.

b. Os três membros em cada trindade possuem certa unidade.

c. Os três membros de cada trindade estão relacionados um ao outro de maneiras trinitárias, a saber, como gerador, gerado e vontade que une (ou amor). Gerador (Pai); gerado (filho); o amor (Espírito Santo) que procede de, e é comum a ambos. 65

A primeira trindade ou tríade exterior é composta de "três coisas" (haec tria [...] res) ${ }^{66}$ :

1. A coisa vista: o objeto. - pode ser anterior ao ato de ver.

2. A visão, ou ato de ver - não pode ser anterior ao objeto. Observar que aqui Agostinho fala da coisa "ser projetada no sentido" (illam obiectam sensui sentiremus).

3. A atenção do espírito (animi intentio) - aqui, se refere ao momento em que o sentido dos olhos se detém sobre o objeto para o ver. ${ }^{67}$

No caso da segunda trindade exterior (que é mais interior que a primeira) ${ }^{68}$ temos o objeto rememorado, sua visão pela cogitatio e a intenção ou vontade que une memória e

\footnotetext{
${ }^{64}$ MacDonalds as chama de "trindades da cognição sensória". Veremos mais a frente como o ato da sensação no homem não pode estar separado do pensamento e da vontade, diferente do que acontece no caso da sensação nos animais que não possuem pensamento.

${ }^{65}$ Para Du Roy este elemento se revela, ao menos de forma mais óbvia, na segunda trindade exterior: "La seconde image évoque le cycle de l'âme: le souvenir est une conversion vers ce qui demeure en la mémoire, conversion qui forme l'esprit et l'unit à son objet. Augustin cherche ensuite dans les relations de ces trois termes une image des processions divines: generation et union" (1966, p.441)

${ }_{66}$ Para Matthews, das trindades analisadas nos livros 9 e 10, somente esta trindade exterior não é puramente mental ou psicológica: "The first object of this trinity is not anything mental. So this trinity is not purely mental or psychological in the way the ones in Books 9 and 10 were" (2002, p.xxi).

${ }^{67}$ No De animae quantitate o primeiro elemento é apenas pressuposto; a visão, ou ato de ver é identificado com a sensação em geral; a animi intentio com o non latens animam.

${ }^{68}$ Optamos pela designação segunda trindade exterior não sem problemas. Nash, por exemplo, ao falar da operação da cogitatio a coloca no homem interior: "The cooperation of the Trinity of the outer man produces the trinity of the inner man, i.e., the image in the memory, the internal vision, and the will. From the cooperation of this trinity comes cogitatio" (2003, p.74). Essa interpretação repousa numa tradução muito apegada a letra do texto em trin. XI, vii, 11 que afirma que essa segunda trindade é interior: iam uero in alia trinitate interiore quidem quam est ista in sensibilibus et in sensibus sed tamen quae inde concepta est, cum iam non ex corpore sensus corporis sed ex memoria formatur acies animi cum in ipsa memoria species inhaeserit corporis quod forinsecus sensimus". A tradução que sugeríamos tenta não se apegar à mera literalidade do termo mais relacioná-la com o contexto da frase que compara essa trindade com a primeira: "Mas já na outra trindade, certamente interior a esta que reside nas coisas sensíveis e nos sentidos, mas que é concebida a partir dela, quando já não é o sentido do corpo que recebe a forma a partir de um corpo, mas é a visão do espírito que recebe a forma a partir da memória quando a imagem do corpo que sentimos no exterior se fixa na mesma memória". Assim, a interioridade da segunda trindade acontece na medida em que é relacionada com a primeira trindade. Assim, como já apontamos anteriormente, as fronteiras e os limites e interioridade são fluídos e se colocam a
} 
pensamento. Nestas duas trindades podemos observar a presença dos três elementos, o gerador, o gerado, e aquilo que é comum a ambos. Na primeira o objeto visto é o gerador, enquanto que a visão o que é gerado a partir do objeto que gera a imagem e por fim, e a vontade que é análoga ao Espírito Santo que está presente na união entre objeto visto e visão. Na segunda temos o objeto na memória que gera a visão interna, unidos ambos, objeto rememorado e pensamento (cogitatio) pela vontade que, por isso, comum a ambos.

Contudo, partindo do princípio de alteridade que rege a relação entre a trindade divina e a sua criação, percebemos que a alteridade é muito mais acentuada na primeira trindade, pois apesar da vontade permitir a unidade entre todos os seus elementos, ainda resta que são substancialmente distintos:

E é assim que, da memória, e da visão interna, e da vontade que une a ambas, se forma aquela trindade; o reunirem-se estas três coisas numa só, chama-se cogitatio a partir de reunião. E, nas três, já nem a substância é diferente. Nelas, com efeito, nem está o corpo sensível, que é absolutamente distinto da natureza do ser vivo, nem se forma o sentido do corpo para que se faça a visão, nem a própria vontade faz dirigir para o corpo sensível o sentido a ser formado e o faz fixar nele depois de formado. ${ }^{69}$

Este trecho mostra que a sucessiva interiorização acontece na medida em que a alteridade dá lugar à identidade. Assim, na primeira trindade do homem exterior temos uma diversidade de substância [diuersa substantia est]: nessa primeira trindade temos o objeto visto que é distinto em substância do segundo elemento da primeira trindade que é a visão gerada a partir do objeto visto e o sentido da vista, ambos chamados de visão por Agostinho. O terceiro elemento seria a intentio animi ou vontade que já é totalmente interior. Este

partir da orientação para a alteridade identificada com o exterior e a identidade com o interior. Resta que esta segunda trindade é mais interior que a primeira, o que poderia nos levar a pensar que a primeira também guarda certa interioridade, o que não é falso. Contudo, adotando a terminologia agostiniana essa trindade, ao ser considerada em relação não à primeira, mas em relação à alteridade ainda é considerada exterior pelo próprio Agostinho: "Daí que o tempo inste comigo para procurar esta mesma trindade no homem interior, e para me encaminhar do homem animal e carnal, que se chama homem exterior, do qual falei tão longamente, para o homem interior". "unde tempus admonet hanc eandem trinitatem in interiore homine requirere atque ab isto de quo tamdiu locutus sum animali atque carnali qui exterior dicitur introrsus tendere" (trin. XI, xi,18). A atividade da cogitatio como veremos a frente ainda guarda, em certo sentido, uma relação com os animais. Outra terminologia, a nosso ver, mais próxima de Agostinho parece ser a Moingt (ver as notas complementeres em La trinité: livres VIII-XV p.611-612) que chama a primeira trindade exterior de trindade da percepção e a segunda trindade exterior de trindade da lembrança, definindo as trindades a partir das atividades correpondentes a cada uma delas.

69 “atque ita fit illa trinitas ex memoria et interna uisione et quae utrumque copulat uoluntate, quae cum in unum coguntur ab ipso coactu cogitatio dicitur. nec iam in his tribus diuersas substantia est. neque enim aorpus illud sensibile ibi est quod omnino discretum est ab animantis natura, aut sensus corporis ibi formatur ut fiat uisio, aut ipsa uoluntas id agit ut formandum sensum sensibili corpori admoueat, in eoque formatum detineat" (trin. XI, iii. 6). 
elemento, obviamente, é que permite a unidade entre os dois primeiros elementos, identificado, portanto, ao Espírito Santo. Contudo, a sensação comparece como momento privilegiado que permite visualizar a unidade dos três elementos dessa trindade; a unidade entre os três elementos da trindade exterior, por sua vez revelam um aspecto que em geral é esquecido quando nos debruçamos sobre o pensamento do hiponense: o papel da teologia na compreensão da sua filosofia.

Um dos aspectos da teologia de Agostinho que, a nosso ver, é fundamental para a devida consideração da sensação é a chamada "doutrina" da inseparabilidade das operações trinitárias. Compreender corretamente tal doutrina permitirá valorizar ainda mais o papel da sensação no pensamento de Agostinho. Queremos mostrar que sem a compreensão da doutrina da inseparabilidade das operações das pessoas trinitárias não podemos entender corretamente o que é a sensação e o seu papel dentro do pensamento de Agostinho, principalmente como se dá a sua compreensão definitiva acerca da sensação. Dessa feita o Hiponense dá um passo além do De quantitate animae revalorizando a sensação a partir das analogias trinitárias que se inserem dentro da ascensão interiorizante.

Portanto, a seguir, em primeiro lugar tentaremos mostrar a importância da sensação como primeira analogia da atividade trinitária, para somente depois nos determos no processo fenomenológico da sensação, que, por sua vez, nos permitirá mostrá-la como uma atividade da alma, trazendo à luz mais um aspecto da relevância filosófica da sensação. Contudo, não devemos esquecer que estes dois elementos da relevância filosófica da sensação são corretamente compreendidos dentro do processo ascensional interiorizante.

\subsection{A Sensação em Analogia com a Doutrina da Inseparabilidade das Operações Trinitárias}

A questão da Inseparabilidade das operações [inseparabiliter operari] das pessoas da trindade é um aspecto dogmático da doutrina da Igreja que, apesar de ter sido desenvolvido por Agostinho, não foi sua invenção. ${ }^{70}$ Segundo Hendrickx, "Les Pères antérieurs à Augustin

${ }^{70}$ Segundo José Maria da Silva Rosa na nota 18 p.25 na tradução portuguesa do De trinitate feita sob a coordenação de Arnaldo do Espírito Santo, Agostinho teria consultado sobre esse ponto vários pais da Igreja nicenos, e alguns pré-nicenos, tais como: "Hilário de Poitiers (De trin., VI, x, 11; XV, iii, 5) [...] Orígenes (De ciu. dei XI, xxiii, 1), Dídimo o Cego (cf. Quaest. in Heptat., II, 25), Gregório de Nazianzo (Trin., XV, xx, 38, citado, mas não identificado; cf. De trin., VII, iv, 9, com a Oratio 21, 1124d-1125a; 42, 477a), Ambrósio de Milão (cf. De doct. christ., IV, xxi, 46), e ainda provavelmente Irineu de Lião, Hipólito de Roma, Tertuliano de Cartago, Mario Vitorino, Basílio de Cesareia (parte do Contra Eunomium), et alii. Em Contra Maximum II, xiv, 3, refere-se diretamente ao Concílio de Niceia". 
n'ont pas toujours suffisamment compris l'unité d'opération des trois Persones divines dans les oeuvres au dehors: opera ad extra" (1997, p.27).

Ao falar sobre a inseparabilidade das operações divinas ad extra e ad intra, tocamos no problema da consideração da trindade econômica e da trindade imamente; para nós, pensar na sensação nos leva a identificá-la nas atividades trinitárias ad extra, enquanto a cogitatio, apesar de ainda ter ligação com a exterioridade, nos conduz às operações ad intra. Entretanto, mesmo na sensação já estão presentes as operações ad extra e ad intra.

\subsubsection{O Problema da Inseparabilidade das Operações Trinitárias antes de Agostinho}

Dentro da história do dogma se convencionou chamar de trindade econômica a consideração da atividade de cada pessoa da Trindade naquilo que em teologia se chama "história da salvação". Essa atividade voltada para a história pode ser chamada de ad extra, ou seja, para fora. Aqui a ênfase está posta na ação das pessoas trinitárias separadamente, ou seja, cada pessoa da trindade tem uma função específica na obra de salvação do homem e consequentemente dentro da história em que se dá tal salvação.

Um exemplo instrutivo é o de Irineu de Lião. ${ }^{71}$ Para esse pai da Igreja:

[O batismo] nos concede a graça do novo nascimento em Deus-Pai, por meio de seu Filho, no Espírito Santo. Pois aqueles que levam o Espírito de Deus são conduzidos ao Verbo, isto é, ao Filho; o Filho os apresenta ao Pai, e o Pai lhes outorga a incorruptibilidade. ${ }^{72}$

Aqui parece ficar clara a ênfase na distribuição (economia) das atividades das pessoas divinas separadamente. Deus Pai concede o novo nascimento que, por sua vez só acontece porque o Filho leva aquele que ainda não nasceu de novo ao Pai, enquanto que o Espírito Santo conduz ao Filho. Assim, temos uma distribuição, e mesmo, hierarquia, das operações das pessoas trinitárias ${ }^{73}$, Pai, Filho e Espírito Santo, na obra divina de salvação.

${ }^{71}$ Colocar os dados dele aqui.

${ }^{72}$ Irineu de Lião, "Demonstração da pregação apostólica” 6-7 in SESBOÜÉ, 2002, p.146.

${ }^{73}$ Contudo, temos que tomar cuidado, pois aqui cometemos certo anacronismo na medida em que o termo "trindade" não é usado nas obras de Irineu. Assim, só podemos falar em trindade a partir de uma consideração posterior, apesar de que, essencialmente os primeiros pais da Igreja já operavam suas reflexões a partir da ideia de que existiam três pessoas divinas que não eram três deuses. Contudo, as indefinições que tal concepção podiam trazer se refletiram na abundante reflexão teológica e filosófica sobre a trindade e nos debates e polêmicas com as “heresias”. Sobre esse aspecto ver SESBOÜÉ, 2002, p.142. 
Quando Hendrickx afirma que os pais da igreja anteriores a Agostinho não compreenderam de modo suficiente as operações das pessoas da trindade ad extra, ele está colocando o problema do conflito entre trindade imanente e trindade econômica.

Antes de Agostinho, ou enfatizava-se as operações das pessoas da trindade separadamente na história, ou a explicação do mistério trinitário em suas relações internas (trindade imanente), de modo que alguns problemas decorriam daí. O primeiro era a polarização ou da imanência (trindade econômica ad extra) ou da transcendência (trindade imanente ad intra). O que Agostinho fará é tentar recuperar e unificar ambos os polos de modo que na trindade imanente esteja presente a trindade econômica e, por sua vez, na trindade econômica esteja presente a trindade imanente. Dito de outra forma: em cada manifestação divina na história da salvação estão presentes e operando ao mesmo tempo as três pessoas da trindade.

Quanto ao segundo problema que decorria da consideração da trindade polarizada, em especial na "economia", temos o surgimento de "heresias". ${ }^{74}$ Os pais pré-nicenos enfatizavam a trindade econômica de modo a criar certo subordinacionismo ${ }^{75}$ entre as pessoas divinas que ajudou a preparar o terreno para o arianismo, ainda que não fosse essa a intenção desses pais.

Chama-se 'subordinacionismo' uma tendência teológica comum aos Padres pré-nicenos segundo a qual o Filho é considerado inferior ao Pai. [...] a perspectiva de fé dos autores em questão, de Justino a Orígenes, é uma coisa, e a adequação de suas elaborações conceituais acerca deles é outra. Não se poderia duvidar seriamente de sua fé na divindade do Filho e do Espírito; em todo caso, a crise ariana não poderia ser explicada se um subordinacionismo pré-ariano se houvesse instalado pacificamente na Igreja no tempo deles [...] É preciso, a seguir, distinguir duas formas de subordinacionismo. Um ortodoxo (embora não seja chamado assim correntemente). É aquele que afirma a prioridade do Pai, na medida em que é fonte e a causa da divindade do Filho e do Espírito. [...] O outro subordinacionismo sustenta que o Filho e o Espírito são, em definitivo, criaturas do Pai, qualquer que seja a sobreeminência deles em relação às outras criaturas (SESBOÜÉ, 2002, p.202).

\footnotetext{
${ }^{74}$ As aspas são necessárias pelo fato de não tomarmos posição teórica a respeito do que é ou não heresia. Só usamos o termo por conveniência linguística e melhor compreensão daquelas ideias que não foram aceitas pelo movimento vencedor no embate ideológico-religioso. No caso aqui, a Igreja Católica.

75 “O subordinacionismo tem outras raízes doutrinais. A primeira é a abordagem 'econômica' do Filho, a única que os Padres pré-nicenos conhecem. O discurso sobre o Filho não incide, como após Nicéia, nas relações intratrinitárias, mas nas relações entre o Pai, de um lado, e, de outro, o Filho em relação com o mundo. É por ocasião do surgimento desse mundo que este Filho se torna 'Filho', no 'momento' que precede logicamente a criação, depois em sua encarnação. A relação Pai-Filho é posta em termos subordinacionistas porque tem em vista o Filho como Verbo 'expresso no exterior', tornado carne” (SESBOÜÉ, 2002, p.202).
} 
É esse "segundo subordinacionismo" que será atacado no Concílio de Niceia, principalmente por Atanásio de Alexandria e, posteriormente pelos Pais Capadócios. Segundo Pannenberg (2009, p.370):

\begin{abstract}
Atanásio e os capadócios enfatizavam a participação de todas as três hipóstases em toda a atividade divina como consequência e condição de sua consubstancialidade. Em decorrência disso, também as diferenças e peculiaridades de Pai, Filho e Espírito não puderam mais ser fundamentadas a partir da diversidade de suas esferas de atuação.
\end{abstract}

A partir da fórmula de Nicéia temos então a passagem de uma concepção econômica de trindade para uma concepção imanente: em cada hipóstase, ou seja, em cada manifestação da trindade, estão presentes todas as pessoas da trindade. Quem permite esse passo teórico é o famoso "consubstancial" "76 ou seja, a fórmula que afirma que as três pessoas divinas possuem a mesma substância, dessa maneira, mesmo falando que tal obra foi operada por uma pessoa divina, não há mais margem a possibilidade de pensar, em decorrência disso, numa possível distinção de natureza entre as pessoas divinas. ${ }^{77}$ Contudo, é Agostinho quem esclarecerá esse ponto na história das ideias de uma forma magistral justamente no De trinitate. Portanto, passemos rapidamente a analisar algumas passagens do livro I numa tentativa de compreensão desse aspecto doutrinário, para daí perceber como ele pode ser compreendido nas duas trindades exteriores analisadas aqui.

\title{
2.2.2. A Inseparabilidade das Operações Trinitárias no Livro I do De trinitate
}

No livro de abertura do De trinitate Agostinho se defronta com o problema da inseparabilidade das operações das pessoas divinas. Já tivemos ocasião de ver como antes de Agostinho esse problema permitiu certa confusão na compreensão da trindade. Advertindo seu leitor de que ele, Agostinho, está inserido na tradição universal, ou majoritária, da Igreja, primeiro afirma a declaração do símbolo apostólico de que "[...] o Pai, o Filho e o Espírito

${ }^{76} \mathrm{Nem}$ de perto pretendemos atacar ou desenvolver esse problema tão complexo e extenso dentro da história dos dogmas. Para tal, ver MORALES, Xavier. La théologie trinitaire d'Athanase d'Alexandrie. Paris: Institut d'Études Augustiniennes, 2006. (Collection des Études Augustiniennes, Série Antiquité, v. 180).

77 "Em Atanásio, a unidade do Filho com o Pai foi fundamentada em outra base do que na relação originária, a saber, a partir da lógica da relacionalidade com o Filho, posta implicitamente no nome de Pai. Com isso, porém, ainda não estava esclarecida a pergunta como a unidade de ambos deveria ser entendida mais detalhadamente. Os capadócios empenharam-se por tal esclarecimento. Eles viram a comprovação da unidade das três pessoas na unidade de sua atuação [...] A teologia dos séculos II e III havia tentado dar uma fundamentação para a diversidade das pessoas trinitárias por meio da ideia de três áreas de atuação distintas" (PANNENBERG, 2009, p.379). 
Santo insinuam, na indivisível igualdade de uma só e mesma substância, a unidade divina $[\ldots]]^{\prime} \cdot 78$

Esta tradição, em seu modo de ver, está ancorada na interpretação dessa tradição universal ou católica. Eis as suas palavras:

Todos os intérpretes católicos dos livros divinos do Antigo e do Novo Testamento que pude ler antes de mim escreveram sobre a Trindade [...] que o Pai, o Filho e o Espírito Santo insinuam, na indivisível igualdade de uma só e mesma substância, a unidade divina [...]. ${ }^{79}$

E depois conclui:

"Esta é também a minha fé, porque esta é a fé católica". ${ }^{80}$

Após essas considerações, na sequência do livro, Agostinho passa a explicar o que ele considera como as características que explicam a inseparabilidade:

[...] a Trindade opera inseparavelmente em tudo aquilo que Deus opera, e, no entanto, ouviu-se uma voz de Pai que não era a voz do Filho; e o que em carne nasceu e sofreu, e ressuscitou e subiu aos céus, foi somente o Filho; e o que veio em forma de pomba foi somente o Espírito Santo. ${ }^{81}$

Voz, encarnação, ressurreição, subida aos céus, vinda, etc., tudo isso pode ser compreendido como ações, ou seja, operações. Todas essas operações que antes de Agostinho eram a tônica da distinção trinitária, agora, apesar de ainda continuarem a ser consideradas como pertencentes a cada pessoa da trindade em particular, não podem dar margem à ideia de que existe diferença de natureza entre essas pessoas como vimos na questão do subordinacionismo. Por isso, há que se esclarecer que a trindade opera inseparavelmente. Como isso acontece?

Em I, vi, 12, ancorado em passagens bíblicas, Agostinho cita diferentes textos onde nalguns se afirma que as coisas são "por intermédio" do Pai e noutros que são "por intermédio" do Filho. Destacamos duas para esclarecimento: em 1 Co 8.6 onde se diz que tudo vem Pai e os fieis estão no Pai, e que todas as coisas são "por meio" do Filho. Depois Rm 11.33-36 onde se afirma de Deus, sem distinção de pessoas, que todas as coisas vêm

78 “pater et filius et spiritus sanctus 'unius substantiae' inseparabili aequalitate diuina insinuent unitatem" (trin. I, iv, 7).

79 “omnes quos legere potui qui ante me scripserunt de trinitate [...] quod pater et filius et spiritus sanctus 'unius substantiae' inseparabili aequalitate diuina insinuent unitatem” (trin. I, iv, 7).

80 "haec et mea fides est quando 'haec est catholica fides" (trin. I, iv, 7).

81 "inseparabiliter operari trinitatem in omni re quam deus operatur, et tamen quandam uocem patris sonuisse, quae uox filii no sit, in carnem autem natum et passum et resurrexisse et ascendisse no nisi filium; in columbae autem specie uenisse non nisi spiritum sanctum" (trin. I, iv, 8). 
“dele", são "por meio dele" e "estão nele". Ora, então não há de fato diferença de natureza entre as pessoas divinas? A resolução de Agostinho é afirmar ambas as coisas, concluindo que tudo é, está e vêm da Trindade:

Pois, se umas coisas são por meio do Pai, outras por meio do Filho, segue-se que não são todas as coisas por meio do Pai, nem todas as coisas por meio do Filho. Mas se todas as coisas são por meio do Pai, e todas são por meio do Filho, são por meio do Pai as mesmas coisas que são por meio do Filho. ${ }_{82}$ Logo, o Filho é igual ao Pai, e é inseparável a operação do Pai e a do Filho.

Apesar de sabermos que cada operação divina é feita por uma pessoa trinitária específica, fica claro desse texto que as outras pessoas divinas estão envolvidas também nas operações. Pessoas divinas, bem dito, contudo, não é citado o Espírito Santo. Mas em outro texto Agostinho expressa que o que é dito do Pai e do Filho também deve ser dito do Espírito Santo:

Não se separe deles, contudo, o Espírito de ambos, isto é, o Espírito do Pai e do Filho, o qual, com propriedade, se diz Espírito Santo, Espírito da Verdade que este mundo não pode receber. [...] Por essa razão, de vez em quando se fala do Espírito Santo como se ele, por si só, bastasse para a nossa bem-aventurança; e de fato ele, por si só, basta, porque não pode ser separado do Pai e do Filho, do mesmo modo que o Pai por si só basta, porque não pode ser separado do Filho e do Espírito Santo, e o Filho, por si só, basta, porque não pode ser separado do Pai e do Espírito Santo. ${ }^{83}$

O trecho mostra que as três pessoas divinas são responsáveis por nos conduzir a beatitude, o que quer dizer que temos aqui uma operação divina em que as três estão envolvidas igualmente, não podendo ser separadas.

\subsubsection{A Inseparabilidade das Operações Trinitárias nas Trindades Exteriores}

Agora, a partir dessa análise doutrinária, parece ficar claro onde está fundamentada a tentativa de Agostinho em mostrar que a compreensão das analogias trinitárias deve partir da identidade. Se, como dissemos anteriormente, a distinção entre exterior e interior se dá a partir

\footnotetext{
82 "si enim alia per patrem, alia per filium, iam non omnia per patrem nec omnia per filium, eadem per patrem quae per filium. aequalis ergo est patri filius, et inseparabilis operatio est patris est filii" (trin. I, vi, 12).

83 "nec inde separatur utriusque spiritus, id est patris et filii spiritus sanctus proprie dicitur, 'spiritus ueritatis quem hic mundus accipere non potest'. [...] propter hoc aliquando ita loquitur de spiritu sancto tanquam solus ipses sufficiat ad beatitudinem nostram; et ideo solus sufficiat quia separari a patre et filio no potest, sicut pater solus sufficit quia separari a filio et spiritu sancto non potest, et filius ideo sufficit solus quia separari a patre et spiritu sancto non postest" (trin. I, viii, 18).
} 
da consideração das coisas como alteridade e identidade, logo, fica claro como o processo de ascensão interiorizante deve buscar a imago trinitatis que está na identidade das operações. Que fique claro, a identidade das pessoas trinitárias é considerada, em especial, a partir da identidade de operações. Deve também ser destacado como agora fica claro que existe uma justificativa filosófica para o dogma trinitário a partir de suas analogias e de como há uma correspondência entre aspecto doutrinal e filosófico. As duas fórmulas, crede ut intelligas e o intelligas ut credas $^{84}$ se completam de forma dialética em Agostinho: o elemento exposto pelo dogma trinitário está presente analogicamente na criação que guarda a imago trinitatis, em especial o ser humano. De posse do dado revelado Agostinho consegue compreender que o ser humano guarda em si uma estrutura triádica onde, esses três elementos não podem agir separadamente um do outro.

Tanto a primeira quanto a segunda trindade exterior são caracterizadas, como já o vimos, pelo fato de serem compostas de três elementos que devem ser considerados como uma unidade: tais elementos expressam essa unidade por meio de suas operações. No caso da primeira trindade exterior temos uma distinção substancial de natureza como aponta Agostinho quando afirma que:

Ao vermos um corpo, são estas três coisas [...] a própria coisa que vemos [...] a seguir, a visão, que não podia existir antes de sentirmos aquela coisa que foi projetada no sentido da vista; em terceiro lugar, aquilo que, no objeto que se vê e durante o tempo em se vê, detém o sentido da vista, ou seja, a atenção do espírito. Nestas três coisas, não só é clara a distinção, mas também distinta a natureza. Primeiro, aquele corpo que é visto é de natureza totalmente distinta do sentido da vista, de cujo encontro consigo a visão se produz: e a própria visão que se mostra, que outra coisa é senão o sentido enformado a partir daquele objeto que é percebido? Embora, retirado o objeto que é visto, não exista nenhuma visão, nem possa existir absolutamente nenhuma, se não existir um corpo que se possa ver, contudo, de modo nenhum é da mesma substância o corpo pelo qual recebe a forma o sentido da vista, quando esse corpo é visto, e a própria forma que a partir dele é impressa no sentido que se designa vista [...] do mesmo modo a atenção do espírito que prende o sentido ao objeto que vemos e os liga um ao outro difere por natureza não só da coisa visível, dado que um é o espírito e o outro é o corpo, mas difere igualmente do próprio sentido e da visão, dado que essa atenção é só do espírito [...] ora, estas três coisas, o corpo que é visto, a própria visão, e a atenção que os une a ambos, são claramente distintas, não só pelo que é próprio de cada um, mas também pela diferença de naturezas. ${ }^{85}$

${ }_{85}^{84}$ Ver em especial o capítulo "Fé e Razão" em NOVAES, 2007, p. 93-128.

85 "cum igitur aliquod corpus uidemus, haec tria [...] ipsa reas quam uidemus [...] deinde uisio quae non erat priusquam rem illam obiectam sensui sentiremus. tertio quod in ea re quae uidetur quamdiu uidetur sensum detinet oculorum, id est animi intentio. In his igitur tribus non solum esta manifesta distinctio sed etiam discreta natura. Primum quippe illud corpus uisibili longe alterius naturae esta quam sensus oculorum quo 
Deixaremos para depois a explicação fenomenológica da sensação. No momento importa mostrar os aspectos de unidade e distinção dentro dessa mesma fenomenologia. ${ }^{86}$ No extenso texto citado acima, fica clara a distinção de natureza e substância entre os três elementos da primeira trindade exterior, o que já é uma deficiência na identificação entre essa trindade e a trindade divina que, como vimos anteriormente, é composta de pessoas de igual substância.

No ato da sensação, os três elementos estão envolvidos, e, por mais que não seja o objeto físico que esteja na visão no ato da sensação, sem a presença do objeto exterior essa visão não pode existir. Contudo, já percebemos uma interiorização e um direcionamento à identidade entre os três elementos quando Agostinho afirma que “[...] de modo nenhum é da mesma substância o corpo pelo qual recebe a forma o sentido da vista, quando esse corpo é visto, e a própria forma que a partir dele é impressa no sentido que se designa vista".

sibimet incidente fit uisio, ipsaque uisio quae quid aliud quam sensus ex ea re quae sentitur informatus apparet?quamuis re uisibili detracta nulla sit nec ulla omnino esse possit talis uisio si corpus non sit quod uideri queat, nullo modo tamen eiusdem substantiae est corpus quo formatur sensus oculorum cum idem corpus uidetur et ipsa forma quae ab eodem imprimitur sensui, quae uisio uocatur [...] itemque illa animi intentio quae in ea re quam uidemus sensum tenet atque utrumque coniungit non tantum ab ea re uisibili natura differt quandoquidem iste animus, illud corpus est, sed ab ipso quoque sensu atque uisione quoniam solius animi est haec intentio. [...] haec igitr tria, corpus, quod uidetur et ipsa uisio et quae utrumque coniungit intentio, manifesta sunt ad dinoscendum non solum propter propria singulorum uerum etiam propter differentiam naturarum" (trin. XI, ii, 2).

${ }^{86} \mathrm{O}$ termo fenomenologia usado aqui não deve ser tomado em sentido estrito se referindo a esta ou aquela escola filosófica, mas simplesmente valorizar um aspecto da experiência humana que, em nosso caso é a sensação, e tentar entender como essa sensação se apresenta ao nosso "espírito". Claro que em alguns momentos o pensamento se aproxima de determinada formulação teórica de outro pensador, como no nosso caso em questão, Husserl. Contudo, que fique sempre claro, o presente trabalho não deve ser visto como um seguimento no sentido mais estrito, mas apenas a apropriação de um termo e determinados conceitos que parecem ajudar na compreensão de nosso problema. No caso da fenomenologia, trata-se de apropriar-se da essência fundamental desse conceito como "apresentar-se" (fenomenologia oriundo do grego phainomenon, ou seja, aquilo que aparece). Visto de modo geral, esse "apresentar" é um aspecto primordial na análise agostiniana da sensação na medida em que, para Agostinho, não se trata de provar a existência do mundo físico, mas ao que esse mundo pode me conduzir: compreender a mim mesmo, à minha alma e a Deus. Se pensarmos que o surgimento da fenomenologia se dá com a valorização do aparecer das coisas, ao invés de se ter uma valorização das próprias coisas factuais como queria o positivismo, então temos tal aproximação. Em notável sintonia com o pensamento Agostiniano nos diz a estudiosa da fenomenologia Angela Ales Bello: "Este é um ponto muito importante: existem os fatos? Certamente, existem. Mas não nos interessa os fatos enquanto fatos, interessamo-nos pelo sentido deles. Por isso posso também 'colocar entre parêntesis' a existência dos fatos para compreender sua essência” (2006, p.23). Para Agostinho também não está em jogo os fatos ou a sua existência, mas o seu sentido. Para o pensamento fenomenológico, em notável consonância com Agostinho, o sentido é dado no sujeito, e não fora dele, como afirma André Dartigues: "Se o objeto é sempre objeto-para-uma-consciência, ele não será jamais objeto em si, mas objeto-percebido, ou objeto-pensado, rememorado, imaginado, etc.” (1973, p.26). Ademais, “[...] a análise intencional conduz, nós o vimos, a distinguir entre sujeito e objeto, ou consciência e mundo, uma correlação mais original que a dualidade sujeito-objeto e sua tradução entre interior-exteriori, já que é no próprio interior da correlação que se opera a separação entre interior e exterior. Mas o acesso a essa dimensão primordial só é possível se a consciência efetua uma verdadeira conversão, isto é, se ela suspende sua crença na realidade do mundo exterior para se colocar, ela mesma, como consciência transcendental." (ibid, p.27,28). 
Ora, a forma presente no sentido da vista já não pode ser identificada ao próprio objeto: já é outra coisa. Não pode ser dita corpórea, apesar dos olhos, segundo elemento da trindade exterior, serem corporais. O sentido da vista, apesar de pressupor os órgãos dos sentidos não é os olhos em si, ou seja, os próprios órgãos dos sentidos, estes são os meios para a sensação como veremos adiante. Portanto, na sensação já temos toda uma fenomenologia que não pode ser dita sensível: tanto a imagem no sentido, bem como a visão e a vontade (animi intentio) já não podem ser ditos corporais. Parece que estamos diante de um processo “espiritual” por assim dizer: a sensação, apesar de se voltar para o exterior, já manifesta um processo interior, de progressiva interiorização.

Rumo a esta interioridade/identidade, um pouco mais a frente Agostinho esclarece que:

[...] embora diferentes em sua natureza, estas três coisas se misturam numa espécie de unidade, ou seja, a forma do corpo que é visto, a sua imagem impressa no sentido da vista, o que constitui a visão ou a sensação formada, e a vontade do espírito que dirige o sentido para o objeto sensível e nele fixa a mesma visão. ${ }^{87}$

Distintas em sua natureza, a distinção não é total, ou seja, não há alteridade absoluta como dissemos acima, pois mesmo que admitamos que exista um objeto externo no ato da visão, não temos acesso direto ao objeto em si, muito menos ele a nós. Temos acesso à sua imagem não corpórea bem como a presença dessa imagem no sentido que já constitui a visão e a vontade. Além do aspecto da incorporeidade a unidade é manifesta no fato de que não existe sensação se estes três elementos não estiverem presentes no mesmo instante, ou seja, há uma inseparabilidade destes três na atividade da sensação, não existe sensação só dos órgãos do sentido, nem existe a sensação da visão sem a atenção do espírito, e muito menos se tenho somente o objeto.

Quanto à cogitatio adentraremos na sua fenomenologia no terceiro capítulo do presente trabalho. Por hora, basta mostrar que ela também pressupõe uma unidade de três elementos. Contudo, essa unidade já é dita por Agostinho como uma unidade em que não há distinção substancial. Portanto, estamos diante de uma imagem mais refinada da trindade divina que é substancialmente idêntica:

87 "tria haec quamuis diuersa natura quemadmodum in quamdam unitatem contemperentur neminerimus, id est species corporis quae uidetur et imago eius impressa sensui quod est uisio sensusue formatus et uoluntas animi quae rei sensibili sensum admouet, in eoque ipsam uisionem tenet" (trin. XI, ii, 5). 
E é assim que, da memória, e da visão interior, e da vontade que une a ambas, se forma aquela trindade; o reunirem-se estas três coisas numa só, chama-se cogitatio a partir de reunião. E, nas três, já nem a substância é diferente. Nelas, com efeito, nem está o corpo sensível, que é absolutamente distinto da natureza do ser vivo, nem se forma o sentido do corpo para que se faça a visão, nem a própria vontade faz dirigir para o corpo sensível o sentido a ser formado e o faz fixar nele depois de formado. ${ }^{88}$

Aqui já podemos perceber certo conflito dentro da fenomenologia Agostiniana já que, no começo de XI, ii, 2 Agostinho tinha listado como pertencentes à primeira trindade exterior o corpo visto, a visão e a atenção do espírito. Contudo, agora parece se efetuar uma passagem onde, para estabelecer uma distinção de natureza, a consideração do segundo elemento é feita a partir do órgão do sentido da visão, e não da visão em si mesma, e mais a vontade. Os dois primeiros eram corporais, enquanto o terceiro incorporal. A sensação em si, ou seja, a visão mesma, não era corporal, mas para se formar deveria ter o concurso desses três elementos que diferiam, já que a vontade que é incorporal tinha que se voltar para o sentido que, por sua vez, era corporal. Aqui na cogitatio os três elementos são incorporais, logo da mesma natureza e substância.

Por fim, outro aspecto que não podemos deixar de lado após todas essas considerações é a relação entre sensação na primeira trindade do homem exterior e as operações ad extra na trindade econômica, bem como a cogitatio na segunda trindade exterior, que é, contudo, mais interior à primeira, com as operações ad intra na trindade imanente; a maior alteridade na primeira trindade exterior se identifica com a trindade econômica na medida em que esta revela a ação de Deus no tempo e mesmo no espaço; onde existe uma maior alteridade. Por sua vez, apesar de não ser plena, a menor alteridade e maior identidade presente na segunda trindade exterior deve ser identificada com as operações ad intra da trindade imanente que considera o deus trindade em suas relações internas, e, portanto, afastadas do tempo e do espaço, as relações fora do tempo, na eternidade.

Ademais, são essas questões das relações entre alteridade e identidade que regem as considerações de uma ascensão interiorizante: não há como pensar na trindade imanente sem pensar numa trindade transcendente, assim como não se pode pensar no homem exterior sem pensar no interior e tomá-lo como fundamento do qual se deve partir para a compreensão do

88 "atque ita fit illa trinitas ex memoria et interna uisione et quae utrumque copulat uoluntate, quae cum in unum coguntur ab ipso coactu cogitatio dicitur. nec iam in his tribus diuersas substantia est. neque enim aorpus illud sensibile ibi est quod omnino discretum est ab animantis natura, aut sensus corporis ibi formatur ut fiat uisio, aut ipsa uoluntas id agit ut formandum sensum sensibili corpori admoueat, in eoque formatum detineat" (trin. XI, iii. 6). 
que ele é. Do mesmo modo, não há como pensar nas atividades trinitárias no mundo sem pensar em suas relações internas.

Portanto, se pensarmos que tanto a sensação como a cogitatio são, respectivamente, operações de cada uma das trindades estudadas aqui, então, apesar de Agostinho não ser explicito quanto a isso, podemos ver claramente que, na medida em que, tanto o ato de sensação, como o ato da cogitatio são atividades que dependem em conjunto dos três elementos de cada uma das trindades, podemos dizer que a sensação e a cogitatio refletem a inseparabiliter operari da Trindade divina.

\title{
2.3.A Sensação na Primeira Trindade Exterior
}

O objetivo da breve exposição acima foi mostrar como as imagens trinitárias exteriores guardam certa semelhança com a trindade divina, e, a partir disso, podermos mostrar a nossa tese de que o processo sensitivo é o momento privilegiado da análise da trindade exterior já que é por ele que observamos, juntamente com a vontade, a unidade presente na primeira trindade exterior.

Nesse sentido, reveladoras são as primeiras palavras de Agostinho em De trin. XI, ii, 2:

\begin{abstract}
Ao vermos um corpo, são estas três coisas, e isso é muito fácil, que devem ser consideradas com atenção e distinguidas: em primeiro lugar, a própria coisa que vemos, seja pedra, seja chama, seja qualquer outra coisa que possa ver-se com os olhos, coisa que, na verdade, podia existir já, mesmo antes de ser vista; a seguir a visão, que não existia antes de sentirmos aquela coisa que foi projetada no sentido da vista; em terceiro lugar, aquilo que, no objeto que se vê e durante o tempo em que se vê, detém o sentido da vista, ou seja a atenção da alma. ${ }^{89}$
\end{abstract}

Nesse trecho de caráter sumário, já aparecem alguns elementos fundamentais para a compreensão do que se seguirá em nossa exposição. O primeiro deles se refere à confirmação de que o homem exterior será compreendido a partir da análise da sensação. Isso fica claro quando Agostinho afirma que “Ao vermos um corpo, são essas três coisas [...] que devem ser consideradas com atenção e distinguidas". Ora, a consideração e distinção dessas três coisas só são possíveis a partir de uma visão de um corpo, ou seja, de uisio corporis. A uisio

89 “cum igitur aliquod corpus uidemus, haec tria, quod facillimum est, consideranda sunt et dinoscenda. primo ipsa res quam uidemus siue lapidem siue aliquam flammam siue quid aliud quod uidere oculis potest, quos utique iam esse poterat et antequam uideretur. deinde uisio quae non erat priusquam rem illam obiectam sensui sentiremus. tertio quod in ea re quae uidetur quamdiu uidetir sensum detinet oculorum, id est animi intentio". 
corporis compreende a sensação que se dá, tanto pelo sentido da visão, como pelos outros quatro sentidos. ${ }^{90}$ Portanto, a consideração do homem exterior como uma semelhança da Trindade só pode ser compreendida a partir de uma análise da sensação.

Agostinho tentará mostrar que existe, nos três elementos da primeira trindade exterior, uma distinctio e uma discreta natura. Ou seja, existe uma distinção de natureza entre ambas. A primeira será a corpo que é objeto da sensação e o sentido da visão. Essa é uma distinção de natureza. A distinção de natureza estaria no fato de que o corpo mais fora (exterior) é um elemento inanimado, enquanto a visão não é simplesmente corpo, pois faz parte de um corpo visto: “[...] a visão, pertence à natureza do ser vivente, que é totalmente distinta daquele corpo que percebemos pela vista". ${ }^{91}$

Esse ponto da distinção de natureza reporta-se à distinção entre sentido e sensação. Isso fica claro pelo exemplo daqueles que possuem o órgão corporal dos olhos, mas esse órgão, de alguma forma, está afetado e não pode receber os estímulos anímicos, ou seja, o órgão corporal dos cegos. Portanto, órgão da visão por si não faz nada, pois os cegos o possuem, sem, contudo, possuírem visão. A partir desses dados podemos distinguir entre órgão corporal e sentido da vista que é identificado com a visão. ${ }^{92}$ Se identificar a visão com o sentido da vista Agostinho poderia cair na identidade entre objeto visto e a visão, já que o órgão corporal que permite a visão, os olhos, são também corporais. Nesse sentido, não poderia existir uma distinção de natureza já que ambos seriam corpóreos.

\footnotetext{
${ }^{90}$ Um ponto que deve ser corretamente esclarecido desde já é ambiguidade do termo latino sensus que ora deve ser compreendido como se referindo aos cinco "sentidos" corporais, o que dá para nós uma ideia de certa potencialidade, bem como "sensação" que para nós seria algo mais ativo, melhor dizendo: o sentido em ação. Por isso, as vezes o termo sensus aparece como um simples meio, que está de alguma forma no corpo, pelo qual a alma se serve. Eis o exemplo do De quantitate animae: "iste... sensus quo anima per corpus utitur" (an. quant. I, xxiii, 41), o que leva imediatamente à resposta de Evódio de que este sensus se refere aos cinco sentidos "Sensus esse quinque". Ao que Agostinho vai explicitar que o que ele quer é maior, a definição que ele deseja tem que abarcar tanto os cinco sentidos quanto todas as outras dimensões que o termo possa alcançar "Uelem autem definiri mihi abs te, quid sit ipse sensus, ut eadem definitione ominia illa includerunt”, nesse caso, ao que parece, o que decorre de certa forma do sentido, a sensação, o sentir, aquilo que é não só a capacidade de sentir, o sentido, mas o próprio "resultado" do fato de não ter se ocultado à alma uma paixão que o corpo sofre. $\mathrm{O}$ problema se agrava mais quando se entende que o verbo pati não é propriamente um verbo que indica ação, mas que indica uma ação sofrida (o que se intensifica pela sua forma depoente que também é a forma da voz passiva em latim, aliás, é pati que dará o vocábulo "voz passiva"), e assim não dá para falar propriamente que a sensação é o sentido em ação, pois não é isso que parece indicar a concepção agostiniana de sensação, mas que nessa primeira definição a sensação, o sentir, muito mais que uma ação, é o resultado de uma ação sobre o corpo, e não do corpo sobre a coisa.

91 "[...] uisio [...] ad animantis naturam pertinet omnino aliam quam est illud corpus quod uidendo sentimus" (trin. XI, ii, 2).

${ }^{92}$ Nesse parágrafo os olhos são chamados de sentidos do corpo por Agostinho, mas não porque eles são corpóreos como os objetos exteriores em geral, mas porque estão num corpo, mas isso não é suficiente, precisa da alma para animar o corpo e, portanto, os sentidos: "But the sense of sight is called a sense of the body for no other reason than the eyes themselves are also members of the body. And though the inanimate body does not experience any sensation, yet the soul, when it is mingled together with the body, does experience sensation through a bodily organ, and this same organ is called the sense" (MATTHEWS, 2002, p.62,63)
} 
Em segundo lugar, devemos considerar e o elemento da atenção da alma (animi intentio) que dirige o sentido ao objeto. Esta "animi intentio" difere, por natureza, da coisa visível e do sentido da visão. No primeiro caso, o que temos é a distinção entre espírito (atenção) e corpo (objeto). No segundo, temos que levar em consideração, como foi mostrado anteriormente, que a vista deve ser entendida juntamente com o órgão da visão. Portanto, são chamados de "sentidos do corpo" essa espécie de união entre corpo e alma. Ora, a atenção é um ato apenas do espírito, enquanto a visão é uma junção entre ato espiritual e corpo num só elemento. Agostinho encerra esse ponto afirmando que esses três elementos estão de certa forma unidos pela atenção, mas são distintos, tanto pelos elementos que pertencem a cada um, ou seja, sua singularidade [propria singulorum], bem como pela diferença de natureza [differentiam naturarum].

Por último, um problema pode surgir quando pensamos na "enformação" do sentido. Esta consiste na visão que se produz da junção entre sentido da visão enformado a partir do objeto percebido. Essa questão possui ressonância filosófica muito importante, pois o que estaria querendo dizer Agostinho com o termo enformado? Seria uma ação do objeto percebido no sentido? Seria uma ação do objeto percebido na alma? Quais são as consequências filosóficas de tal posicionamento? Tentaremos mostrar que no pensamento Agostiniano o inferior não pode agir sobre o superior, ou seja, os objetos sensíveis não podem agir na alma. Como explicar esse problema? Tentaremos buscar uma resposta na descrição do processo sensitivo.

Contudo, antes de proceder à consideração do processo da sensação, já que estamos falando em visão do sentido corporal talvez seja instrutivo esclarecer o que são a uisio corporis e uisio spiritualis, e porque Agostinho toma o exemplo da visão como extensivo a todos os outros sentidos.

\subsubsection{Visio Corporalis e Visio Spiritualis}

Na sequência das considerações sobre o homem exterior e a sensação, ao falar sobre os sentidos Agostinho no final de XI, i, 1 afirma que

Demorado seria, e desnecessário, interrogarmos os cinco sentidos sobre aquilo que investigamos; na verdade, o que um deles nos revela vale também para os outros. Usemos então preferencialmente o testemunho dos olhos; 
este é na verdade, o mais nobre dos sentidos do corpo e, salvaguardada a diferença de gênero, o mais próximo da visão da mente. ${ }^{93}$

Duas coisas devem ser notadas nesse texto que são fundamentais para a compreensão de nosso problema. A primeira se refere à unidade dos sentidos, e a segunda à importância do sentido da visão como sentido privilegiado na consideração da sensação. ${ }^{94}$ Apesar de ambos estarem inter-relacionados, podem ser considerados separadamente. Entretanto, antes de tal consideração talvez seja instrutivo definir alguns termos que levem ao esclarecimento do nosso problema.

O sentido da visão, também pode ser chamado de uisio corporis. Mas o que esta seria? Em geral à uisio corporis se juntam ainda mais duas espécies de visão, a uisio spiritualis e a uisio intellectualis. ${ }^{95}$

\subsubsection{Visio Corporalis}

As três classes de visões listadas acima são especificamente discutidas em Gn. litt XII, vii, 16-xxxi,59. No caso da uisio corporis sua consideração é desenvolvida consideravelmente nesses parágrafos. Contudo, a definição das três espécies de visão dá-se precisamente em XII, vii, 16:

Denominemos corporal a primeira, porque se percebe pelo corpo e se apresenta aos sentidos do corpo. A segunda espiritual, pois tudo o que não é corpo e, no entanto, é algo, diz-se com razão espiritual; não é certamente corpo embora sejam semelhantes ao corpo, a imagem do corpo ausente e o próprio olhar com que se contempla a imagem. A terceira denomina-se intelectual, porque procede da inteligência. ${ }^{96}$

Por hora nos deteremos na visão corporal. Duas coisas devem ser notadas na definição dada acima. A primeira parece falar especificamente da sensação da visão, a segunda, por sua vez se refere ao fato de que ela "se apresenta a todos os sentidos do corpo". Ora, é estranho pensar que a visão se apresenta a todos os sentidos do corpo se aos outros sentidos são atribuídas outras sensações. Mas a visão é corporal, indicando que o termo se aplica ao corpo

\footnotetext{
93 "sed et multum est et non necessarium ut omnes hos quinque sensus id quod quaerimus interrogemus; quod enim nobis unus eorum renuntiat etiam in ceteris ualet. itaque potissimum testemonio utamur oculorum; is enim sensus corporis maxime excellit et est uisioni mentis pro sui generis diuersitate uicinior".

${ }_{95}^{94}$ Mais dois elementos ausentes na consideração da sensação no De animae quantitate.

${ }^{95}$ Ver Gn.litt. XII, x, 22.

96 "Primum ergo apellemus corporale, quia per corpus percipitur et corporis sensibus exhibetur; secundum espiritale: quidquid enim corpus non est et tamen aliquid est, iam recte spiritus dicitur et utique no est corpus, qumuis corpori similis sit imago absentis corporis, nec ille ipse obtutus, quo cernitur; tertium uero intellectuale ab intellectu".
} 
todo, e, portanto, a todos os sentidos. Aqui estamos diante de um caso onde o todo é tomado pela parte.

É claro que o termo é usado não no sentido literal, mas uma possível explicação seja a de que todas as sensações experimentadas por meio dos sentidos fazem parte do mundo corporal e visível. ${ }^{97}$

Mais abaixo nos determos especificamente no tratamento da visão como sentido privilegiado em relação aos outros sentidos, e por isso, considerado na análise da sensação no De trinitate. Entretanto, por hora, precisamos ainda de outros elementos conceituais para nos lançarmos em tal empreitada; antes de tudo, cumpre analisar a visão espiritual e o sentido interno. De posse desses dados poderemos nos debruçar sobre a análise específica da uisio corporis.

\subsubsection{Visio Spiritualis}

Retomemos o texto do Gn. litt. XII, vii, 16, mas apenas a parte que define a visão espiritual $^{98}$ :

A segunda espiritual, pois tudo o que não é corpo e, no entanto, é algo, dizse com razão espiritual; não é certamente corpo embora sejam semelhantes ao corpo a imagem do corpo ausente e o próprio olhar com que se contempla a imagem. ${ }^{99}$

Agostinho lista as características do que pode ser espiritual: 1. Ser alguma coisa; 2. Não ser corporal; 3. Ser uma imagem do corpo ausente (aqui se pensa não num desenho, mas numa imagem na memória); 4. A visão dessa imagem na memória.

Em Gn. Litt.. XII, ix, 20 encontramos outra definição de uisio spiritualis e que parece conter basicamente alguns elementos listados acima. Diz-nos Agostinho: “[...] Eu tenho designado como visão espiritual o tipo de visão pela qual nós cogitamos ${ }^{100}$ na mente as imagens dos corpos, mesmo na sua ausência”. 101

${ }^{97} G$. litt, XII, xxiv, 51. Bubacz argumenta a favor dessa tese o fato de que a luz é o melhor dos elementos do mundo corporal e também que qualquer objeto corporal é objeto da visão corporal (1981, p.98). Sobre o caso da uisio corporis como se apresenta no De trin. XI, ii, 3 afirma que: "However, bodily sight is not our source of knowledge of the material about things [...]. In order to determine how Augustine accounts for our knowledge of the material world we must follow the messages sent by the messengers of the soul to the second sort of vision that he discusses" (Idem, p.99).

${ }^{98}$ O termo espiritual, em nossa língua, tem primariamente o sentido de transcendência, algo meio indefinido, mas que está afastado das questões físicas, materiais e corporais; em Agostinho, por sua vez, o termo tem um sentido muito preciso como se dará no desenvolvimento da seção.

99 "secundum espiritale: quidquid enim corpus non est et tamen aliquid est, iam recte spiritus dicitur et utique no est corpus, qumuis corpori similis sit imago absentis corporis, nec ille ipse obtutus, quo cernitur;".

${ }^{100}$ Não traduzimos cogitamos por pensamos como se faz usualmente, pois, em Agostinho este parecer ser um termo muito preciso e que é usado em outro sentido, precisamente o etimológico. Como veremos com 
Definamos: uma coisa é o espiritual e outra é a visão espiritual. Nem tudo o que se possa chamar de espiritual é uma visão espiritual, mas toda visão espiritual é algo espiritual. Portanto, no caso da uisio spiritualis ela não pode ser dita uma imagem do corpo ausente, no entanto, ela pode lidar com essa imagem na sua memória, pois tanto a visão espiritual, quanto a imagem da coisa ausente, quando na memória, são consideradas como de ordem espiritual. Mas isso não é tudo, analisando um pouco mais essa questão, logo somos levados a perceber que essa capacidade de reter a imagem na memória também está presente nos animais, a ponto de um autor como Bubacz sugerir que se traduza o termo por visão animal e O’Daly faça menção a uma animal sight, ${ }^{102}$ já que estamos tratando de uma capacidade de seres animados como os homens e os animais (bestae). De nossa parte, continuaremos utilizando o

mais detalhes a frente, o verbo cogito é formado pelos verbos ago, "levar" do qual deriva o verbo coagerecogere "juntar", e o substantivo coactus que é o resultado da ação de juntar: "reunião". Essa associação etimologica é aproveitada por Agostinho em trin. XI, iii, 6 para definir a cogitatio como a reunião de uma série de atividades do homem interior que colhem a imagem e a deixam a disposição da memória. Essa atividade não pode ser relacionada necessariamente com o pensamento, pois os animais a possuem também. O que pode ser discutido é se, como acontece com a sensação, no homem, tanto a cogitatio como a sensação não se separam do pensamento. Pretendemos abordar isso mais a frente.

101 "secundum hanc, inquam, distinctione spiritale nunc appellauimus tale genus uisorum, quali etiam corporum absentium imagines cogitamos". Interessante notar que nesse trecho aparece o termo cogitamos, do verbo cogitare, o mesmo ligado à atividade do homem interior em De trin, XI.

${ }^{102}$ Para Bubacz, não se recomenda traduzir literalmente esse termo por visão espiritual, pois ela não é uma visão peculiar para coisas espirituais, mas se refere à visão de todas as coisas que respiram, portanto, aos animais também. Assim, Bubacz usa, de fato, dois termos: "visão animal" e "visão espiritual" (1981, pg. 100). Aqui ele se aproxima da concepção de O'Daly para quem, no caso da consideração de uisio spiritualis como visão animal: "There are contexts in which Augustine indicates that the functioning of animal sight is not a sufficient condition for the inner-man's learning about the corporeal world" (1987, pg. 100). Para este exemplo ele alude à experiência de andar sem se perceber do que está a sua volta. Bubacz fala sobre esse exemplo que se encontra em De trin. XI, viii, 15, onde Agostinho explica que é possível caminhar sem que a "atenção da vontade" (intenta [...] uoluntate) se volte ao caminho, nesse caso o caminhante em questão não sabe (nesciunt) por onde passou. Ora, esse exemplo pode ser também aplicado aos animais que, ao que parece, podem fazer o caminho sem a necessidade do uso da razão, ou seja, eles também, obviamente, não sabem (nesciunt), reflexivamente tudo o que se passa ao seu redor. O exemplo se coaduna com a concepção de O’Daly de visão espiritual como uma espécie de visão interna. Essa visão estaria relacionada com o senso de percepção que compartilhamos com os animais. Exemplo disso é De quant. an. I, xxviii, 54 - Aqui ele fala que os animais possuem o senso de percepção que nós temos também, mas os homens são capazes de conhecer o mundo corporal apresentado pela visão animal. Ora, ao que parece os animais também possuem esta espécie de visão, mas ela também aparece na consideração da cogitatio no De trinitate. Assim: "Humans have a capacity that animals lack: they can learn things through the images reported by animal sight" (pg.101). Em suma, para Bubacz, aquilo que entra no âmbito da cogitatio estudada no livro XI é o mesmo que uisio spiritualis, no sentido de uisio animal. Outro pesquisador que trabalha essa questão das visões é Ronald Nash. Para Nash também existem três níveis (levels) de percepção ou visão: visão corporal, espiritual e intelectual. Ele coloca como percepção apenas a visão corporal: "This chapter will concentrate on Augustine's teachings about corporeal vision or sense perception" (p.39). Quanto à visão espiritual ela aparece no capítulo cinco de sua obra, capítulo que fala da cogitação. Nesse ponto Nash parece se separar de Bubacz, pois em relação ao homem interior afirma o seguinte: "Capacities that man does not share with the beasts belong to the inner man. Included in the latter class are man's ability to judge, compare, and measure sensation" (p.60). Todas essas capacidades de fato pertencem ao homem interior, entretanto, contra Nash, podemos afirmar que os animais comparam e medem sensações de alguma forma; essa capacidade interior pode se referir como já mostraram O'Daly e Bubacz que os homens partilham com os animais, principalmente dentro daquilo que é entendido como "sentido interno". Gilson, por sua vez, (2006, nota 3, p.120) fala em duas espécies de visão (uisiones), a visão corporal, na qual o olho é informado (formatur) pela forma (species) do objeto; e a visão espiritual, na qual o pensamento (cogitatio) é informado (formatur) pela forma (species) conservada na memória. 
termo Agostiniano, uisio spiritualis, pois em nossa língua o termo animal está muito ligado aos animais irracionais podendo ser fonte de mal entendidos. Entretanto, guardemos o fato de que ele se refere a uma capacidade que compartilhamos com os animais.

O último argumento sobre o alcance da uisio spiritualis aparece em De gen, ad litt XII, viii, 19 - ix, 20. Nesses parágrafos Agostinho procura marcar a distinção entre uisio spiritualis e uisio intellectualis que aparecerá explicitamente em XII, x, 21. Nos textos de De gen, ad litt XII, viii, 19 - ix, 20, apoiando-se no texto bíblico de 1 Co 14.14 que fala sobre o dom de línguas, Agostinho afirma a distinção entre spiritus e mens. Eis o texto paulino na versão latina de Agostinho: "Se eu orar em língua, diz ela, o meu espírito ora, mas minha mente fica infrutífera"103

A seguir Agostinho associa a essa linguagem "espiritual" alguns obscuros e místicos significados que não são por si mesmos compreendidos: são como imagens e semelhanças das coisas, que, contudo, precisam do olhar da mente para serem entendidos (quae ut intellegantur indigent mentis obtutu). Esse ponto estaria fundamentado no seguinte texto, também de Paulo de 1 Co 14.2 que afirma que "aquele que fala em línguas não fala aos homens, mas a Deus, ninguém o ouve ${ }^{104}$, porém o espírito fala mistérios". 105

Não precisamos nos aprofundar mais, pois do exposto, parece ficar claro pelo exemplo que as línguas espirituais são ininteligíveis, por isso pertencem também à uisio spiritualis, portanto, a visão espiritual é que recebe informações que, sem o entendimento, o intellectus, não podem ser compreendidos.

Depois dessa exposição o que podemos concluir ao menos de modo parcial? Com base nos comentários parece plausível pensar que a uisio corporalis está ligada à primeira trindade exterior que lida com a sensação, enquanto que a uisio spiritualis se refere à segunda trindade exterior, que, no entanto, é mais interior que a primeira. Nesse caso, não interior no sentido de superioridade intelectual, mas na capacidade que, apesar de apreender species das res corporalia como na sensação, as ultrapassa por também ser capaz de formar imagens por composição, a partir das imagens obtidas pela uisio corporalis. Essa capacidade cogitativa é muito parecida com a cogitatio tratada por Agostinho em De trin, XI, iii, 6 e que será desenvolvida no terceiro capítulo do presente trabalho. Entretanto, o tema da unidade dos

103 "Si enim orauero, inquit, lingua spiritus meus orat; mens autem mea infructuosa est" (De gen. ad litt. XII. viii, 19)

${ }^{104}$ Aqui compreender o ouvir com entendimento.

105 "qui enim loquitur lingua, non hominibus loquitur, sed Deo; nemo enim audit, spiritus autem loquitur mysteria" (idem) 
sentidos num só, como, por exemplo, a visão corporal, evoca a questão do "Sentido Interior" tratado por Agostinho e que parece fazer parte da uisio spiritualis.

\subsubsection{Unidade dos Sentidos e Sentido Interior}

Para Bubacz, a unidade dos sentidos é possível por causa do emprego da razão pelo homem interior. ${ }^{106}$ Essas palavras podem ser interpretadas no sentido de que a razão percebe essa unidade dos sentidos. Entretanto, mais do que a razão, existe outro elemento do homem interior chamado por Agostinho de "certo sentido interior" (interiorem quemdam sensum), que, parece perceber a própria percepção, ou seja, a sensação. Esse termo aparece no livro II do De libero arbitrio quando Agostinho trata da distinção entre sensação e ciência. Em algum momento do diálogo entre ele e Evódio surge o problema da possibilidade de um intermediário entre a sensação e a razão. Esse ponto é esclarecedor por que mostra que nesta obra Agostinho parece dar um passo a mais em relação à distinção entre sensação e ciência (que aqui corresponde ao elemento racional do De libero arbitrio) feita no De quantitate animae. Esse passo é explicado por Agostinho quando ele justifica que não há como conceber os processos que se dão desde a sensação até a razão sem uma espécie de mediação ou hierarquia.

Essa razão poderia distinguir esses quatro ${ }^{107}$ uns dos outros e os determinar em definições, se ela não recebesse comunicação da cor pelo sentido dos olhos, e desse sentido pelo sentido interior que os preside, e o próprio interior por si mesmo, se não estivesse, portanto, nenhum outro intermediário $?^{108}$

Portanto, o intermediário entre a sensação e a razão é o sentido interior que preside tanto a sensação quanto o sentido (qualquer sentido, no caso aqui, o da visão), e inclusive a si mesmo. É ele quem permite que todos esses três "elementos" possam chegar até à consideração da razão, que, por sua vez, considerará todos os passos precedentes.

$\mathrm{Na}$ continuidade da investigação Evódio fala em dois momentos. Um primeiro se refere a uma capacidade de organização dos sentidos e dos dados obtidos por meio dos

106 "The unification of the reports of these senses is accomplished by the inner-man's employment of reason”. (BUBACZ, 1981, p.118).

${ }^{107}$ A cor que é sentida, o sentido que está no olho, o sentido interior que está na alma e a razão que define e enumera em detalhe tudo isso: "Num etiam putas eas posse discernire ab inuicem colorem qui sentitur et sensum qui in oculo est et illum interiorem sensum apud animam et rationem qua ista singillatim definiuntur et dinumerantur?" (De lib. arb. II, iii, 9)

108 "ista ratio posset haec quattor discernere ab inuicem et definitionibus terminare, nisi ad eam referretur et color per oculorum sensum et ipse rursus per illum interiore qui ei praesidet et idem interior per se ipsum, si tamen iam nihil aliud interpositum est?" (De lib. arb. II, iii, 9). 
sentidos. $\mathrm{O}$ outro momento se refere à capacidade de julgar esses dados: o sentido interior “julga" os sentidos, a razão julga o sentido interior, e a razão é julgada pelas regras acima da nossa razão. Importante é notar que o posterior julga o anterior, o que permite a existência de uma hierarquia a partir de níveis de julgamento.

Por meio do exemplo de que fazemos a distinção entre a cor, o ato de ver a cor, e a capacidade de ver a cor, mesmo esta não estando presente, ${ }^{109}$ Agostinho pode concluir que esta capacidade que permite ao homem ver a cor é uma espécie de função vital chamada de sentido interior (illa uita sit, quam sensum interiorem uocamus - De lib. arb. II, iii, 9).

Além dessa capacidade, parece que este sentido interior ainda pode unificar todos os sentidos em um só: ${ }^{110}$

Eu penso mais que a razão, nos faz saber que existe certo sentido interior, ao qual todos os cinco sentidos que conhecemos se referem. ${ }^{111}$

É ainda o sentido interior que recebe os dados sensíveis em conjunto e que permite a comunicação entre os sentidos quando apreendem esses "comuns". Além disso, o sentido interior apreende os próprios sentidos: ele tem a percepção de que é dotado de sentidos ou sensações (Bermon, 2001, p.51,52). Tal percepção se dá por meio da consideração de que os animais têm a percepção que possuem sensação, ou mais literalmente, que sentem que têm sensação:

É evidente, também, julgo eu, que o sentido interior não percebe somente os objetos que recebe dos cinco sentidos corporais, mas percebe os sentidos mesmos. Pois o animal não se moveria para buscar um objeto ou para evitálo, se ele não sentisse que sente, não para ter ciência, pois isto é próprio da razão, mas somente para se mover, o que certamente não percebe por um dos cinco sentidos. ${ }^{112}$

Ora, é pelo sentido interior, e não por algum dos sentidos que o animal tem o que poderíamos chamar de uma espécie de "intuição" sensível acerca de suas sensações. Isso pode

\footnotetext{
109 "enitere etiam ista diiudicare. Nam credo te non negare aliud colorem esse et aliud colorem uidere et item aliud, etiam cum color non subest, habere sensum quo uidere posset si subesset" (idem).

${ }^{110}$ Para Bermon, essa "referência" explicita a capacidade de perceber os sentidos em conjunto: "Le sens intérieur est donc premièrement désigné comme le sens qui recueille tous les donnés sensibles, et qui permet de faire communiquer entre eux les différents sens lors de la saisie des 'communs"” (2001, p.51).

111 "Magis arbitror nos ratione comprehendere esse interiorem quemdam sensum, ad quem ab istis quinque notissimis cuncta referantur".

112 “arbitror etiam illud esse manifestum, sensum illum interiorem non ea tantum sentire quae accepit a quinque sensibus corporis, sed etiam ipsos ab eo sentire. Non enim aliter bestia moueret se uel adpetend

o aliquid uel fugiendo, nisi se sentire sentiret, non ad sciendum, nam hoc rationis est, sed tantum ad mouendum, quod non utique aliquo illorum quinque sentit" (De lib. arb. II, iv, 10)
} 
ser compreendido com mais propriedade através do exemplo prático de um animal que não moveria os olhos para ver se não sentisse que é impossível ver tendo os olhos fechados ou tendo limitada ou problemática a capacidade de movimento desse mesmo sentido. ${ }^{113}$

Em suma, o que podemos depreender da análise da uisio spiritualis e o sensus interior é que este último se refere ao que parece à uisio spiritualis, sem necessariamente ser identificada com esta, pois a uisio spiritualis não fala apenas da capacidade da interioridade de lidar com a sensação e unificá-las numa só, como é o caso da visão em relação aos outros sentidos, mas também, quando compreendida na natureza humana, refere-se a outro elemento da interioridade, a capacidade cogitativa. ${ }^{114}$

Entretanto, um ponto que deve ser considerado com cuidado nessa análise do "sentido interior" é não o ver como "algo". O mesmo princípio do uso dos termos interior e exterior em relação à orientação do homem deve comparecer na compreensão do "sentido interior". Assim, não existem dois sentidos, um exterior e outro exterior, mas sim uma atividade da alma que ao se voltar para a alteridade dos corpos em si mesmos é chamada de sentido exterior, enquanto a consideração da alma em relação aos próprios sentidos em ato no momento da sensação é chamada de sentido interior, ou seja, o afastamento em relação à alteridade corporal é maior.

\subsubsection{A Superioridade do Sentido da Visão Sobre os Outros Sentidos}

Esclarecido que a visão corporal se refere ao sentido da visão, e que visão espiritual/animal está relacionada ao sentido interior e à segunda trindade exterior, podemos agora nos concentrar na análise da superioridade do sentido da visão sobre os outros sentidos.

Agostinho trata dessa questão da nobreza do sentido da visão sobre os outros sentidos em De gen ad. litt. XII, xvi, 32. Nesse parágrafo mostra a visão como o sentido que capta o elemento natural mais próximo da substância da alma, ou seja, a luz. E como, de certo modo, os outros sentidos derivam de certa junção entre luz, tipos de ar, densidade da terra e sentido da vista. Assim, raciocina-se que aquele sentido que capta a luz em seu estado mais puro seria superior. Tentemos analisar com mais clareza como isso se dá.

113 "si animaduertas quod exempli gratia sat est in uno aliquo sensu, uelut in uisu. Namque aprerire oculum et mouere aspiciendo ad id quod uidere adpetit nullo modo posset, nisi oculo clauso uel no ita modo se id no uidere sentiret" (idem)

${ }^{114}$ Sobre a cogitatio ver mais a frente. 
Uma das razões dadas por Agostinho à prioridade da visão é a de que ela, entre todos os sentidos, é a que mais se aproxima do conhecimento intelectual. ${ }^{115}$ Vale a pena lembrar o texto citado anteriormente e tentar compreender as afirmações nele contidas:

"Demorado seria, e desnecessário, interrogarmos os cinco sentidos sobre aquilo que investigamos; na verdade, o que um deles nos revela vale também para os outros. Usemos preferencialmente o testemunho dos olhos; este é, na verdade, o mais nobre dos sentidos do corpo e, salvaguardada a diferença de gênero, o mais próximo da visão da mente". ${ }^{116}$

A primeira parte dessa citação afirma certa unidade dos sentidos. A hipótese que viemos desenvolvendo até agora é que essa unidade é possibilitada, em última instância, por essa capacidade da alma chamada de sentido interior. Entretanto, de que unidade dos sentidos falamos quando nos referimos ao sentido interior? Não parece ser a mesma tratada aqui. No caso do sentido interior, tivemos a ocasião de observar que sua função consiste em unificar os dados exteriores obtidos pelos sentidos, proporcionar a comunicação entre os sentidos, e, por fim, proporcionar certa "intuição", ou "sensação", que qualquer ser animado tem de que possui sentidos exteriores. Em suma, o sentido interior se refere à capacidade organizacional da alma em interiorizar os sentidos externos, ou seja, os cinco sentidos: trata-se de uma capacidade quase judicativa, mas é claro, que não é em si mesma racional e que atua sobre os sentidos externos. ${ }^{117}$

Ora, no caso da unidade dos sentidos que é tratada aqui, Agostinho não faz referência a tais elementos presentes na consideração do sentido interior; podemos afirmar que, enquanto o sentido interior traz uma unificação da sensação em si mesma, a unidade dos sentidos a que Agostinho está se referindo no De trinitate está relacionada a um fundamento ontológico. Vejamos se isso fica mais claro a partir da análise do texto de Gn. litt.

${ }^{115}$ Há uma relação entre uisio intellectualis e a mens.

116 "sed et multum est et non necessarium ut omnes hos quinque sensus id quod quaerimus interrogemus; quod enim nobis unus eorum renuntiat etiam ceteris ualet. itaque potissimum testemonio utamur oculorum; is enim sensus corporis maxime excellit et est uisionem mentis pro sui generis diuersitate uicinior" (trin. XI, i,1).

${ }_{117}$ É curioso pensar como tais considerações reaparecerão, de alguma forma, na chamada "psicologia das profundezes" de Carl Gustav Jung que, no seu clássico, "Os Tipos Psicológicos", coloca o sentimento/sentir como uma capacidade judicativa, mas que difere do pensamento: "O sentir é, portanto, uma espécie de critério julgador, mas diferente do juízo intelectual, na medida em que não revela propósitos de estabelecimento de uma conexão conceitual, mas apenas um intuito de aceitação ou recusa subjetiva" (1967, p.540). O mesmo Jung faz a distinção entre esse tipo de sentimento e a intuição. Contudo, a nosso ver, mesmo que tal distinção possa ser útil em termos técnicos, a intuição guarda certos aspectos do que aqui tratamos como pré-racional: "Na intuição, qualquer conteúdo nos é oferecido como um todo coeso, sem que sejamos capazes de dizer ou averiguar, de imediato, como teria chegado a formar-se. A intuição é uma espécie de adaptação instintiva de qualquer conteúdo". 
[...] o sentido do corpo relaciona-se com as visões corporais, e ele se distribui como que por cinco riachos dotados de poder mesmo a distancia. ${ }^{118}$

O sentido do corpo, tomado aqui no singular, parece fazer referência, como veremos, ao sentido da visão. Entretanto, em última análise, o sentido da visão, ou uisio corporis, como tivemos ocasião de ver acima, não estaria restrito às sensações referentes aos olhos corporais, mas pode ser aplicada a todas as sensações dos outros sentidos. ${ }^{119}$ Essa tese pode se apoiar na própria analogia feita por Agostinho acima, onde a origem e inter-relação entre os sentidos se dá se modo semelhante à inter-relação entre um rio ou fonte que se distribui em riachos; a imagem é altamente esclarecedora, pois ela pode afirmar tanto a origem única dos sentidos no sentido da visão, bem como ao fato de que todos os sentidos possuem, em última análise, a mesma essência, por assim dizer. Mas talvez não seja produtivo tentar ir muito além do que a imagem propõe sem o apoio dos textos. Vejamos o que Agostinho diz:

O que existe de mais sutil nos corpos e, que por isso, é mais próximo da alma que os demais, é a luz, que se difunde primeiro somente por meio dos olhos e brilha nos raios dos olhos para ver as coisas visíveis. Em seguida, por meio de certa mistura, primeiro com o ar puro, em segundo lugar com o ar mais denso e nebuloso, em terceiro lugar com o vapor mais denso, em quarto lugar com a densidade da terra, constituí com o sentido da vista, no qual apenas a luz se sobressai, os cinco sentidos $[\ldots]^{120}$

O termo latino "primum per oculos" parece dar a ideia não somente de prioridade ontológica do sentido da visão sobre os outros sentidos, mas prioridade temporal. O trecho pode ser interpretado no sentido de que, em última instância, toda sensação começaria com a visão, pois mesmo no caso da composição das sensações nos outros sentidos, existe, literalmente, uma mistura [mixtura], como falamos anteriormente, de luz vapores e densidade com o sentido da vista, que, "gera" os outros sentidos.

Contudo, talvez mais central para o que pretendemos estabelecer seja o fato da proximidade da luz em relação à alma. Guardemos esse fato, pois certamente temos aqui a temática da identidade relacionada com a interioridade e que funda superioridade, na medida

118 "[...] pertinet corporis sensus ad uisa corporalia, qui per quinque quasi riuulos distanter ualentes" (Gn. litt. XII, xvi, 32).

${ }^{119}$ Que fique claro aqui a distinção por nós já feita anteriormente entre sentido da vista e sensação. Nesse caso aqui, uisio corporis se refere à visão em ato, ou seja, a junção entre objeto visto, sentido da vista e a vontade que une os dois primeiros, e não simplesmente ao sentido da vista.

120 "quod est subtilisimum in corpore et ob hoc animae uicinius quam cetera, id est lux primum per oculos sola diffunditur emicatque in radiis oculorum ad uisibilia contuenda, deinde mixtura quadam primo cum aere puro, secundo cum aere caliginoso atque nebuloso, tertio cum corpulentiore humore, quarto cum terrena crassitudine quinque sensus cum ipso, ubi sola excelit, oculorum sensu efficit" (idem). 
em que existe uma identidade entre luz e alma, pois ambas estão mais afastadas da corporeidade difusa.

Quanto à questão da prioridade temporal, podemos questioná-la ao afirmar que nem sempre que temos sensações de outra ordem que a da visão estamos vendo em ato. Por exemplo, podemos experimentar todas outras sensações com os olhos fechados. Uma possível resposta a tal indagação poderia ser dada por meio da constatação de que, sempre que experimentamos certa sensação, mesmo que o objeto que dá origem à sensação não está presente ao sentido da visão, por exemplo, quando os olhos estão fechados, nós imaginamos a forma daquilo do qual experimentamos a sensação.

Entretanto, tal fenômeno da imaginação da sensação já se dá num nível de interioridade que requer o uso da memória, portanto, estaríamos ultrapassando o nível da pura fenomenologia sensível. Ao voltarmos-no novamente para o trecho de nossa análise com mais cuidado, percebemos que ele não trata de uma simultaneidade de sensações onde sempre a precisamos ter uma uisio corporis como condição de outras sensações. Na verdade, o texto fala na mistura [mixtura] entre os elementos e o sentido da vista e não uma mistura com a visão [uisio corporis]. Nesse caso, tal junção se dá entre mistura dos elementos corporais com o elemento da luz que primeiro atinge o sentido da vista para daí se propagar para os outros sentidos. Daí decorre a prioridade ontológica da uisio spiritualis, pois mesmo que ela não esteja acontecendo em ato no momento em que temos outra sensação, o sentido da visão que é o sentido envolvido na uisio corporis é o primeiro dos órgãos dos sentidos, tanto a nível temporal como ontológico.

De fato, esse é um trecho de difícil interpretação se operamos apenas com os dados desse parágrafo. Para confirmar a tese precisamos de outros textos. Na sequência, Agostinho afirma que tratou disso tanto no quarto quanto no sétimo livro do próprio De genesi ad litteram. No entanto, nesse livro encontramos apenas um breve resumo em IV, xxxiv, 54, enquanto que uma exposição de fato acontece em III, iv, 6-v, 7. Quanto ao livro VII, a referência é exata, já que o tratamento da questão se encontra em dois lugares, tanto xiii, 20 quanto uma dissertação mais extensa que cobre dois parágrafos xix, 25-26.

No caso da primeira passagem, no livro IV, não encontramos elementos suficientes para a nossa análise, apenas uma referência à capacidade do sentido da visão, que, por meio de raios emitidos dos olhos alcança grandes distâncias; tema que se encontra no trecho que estamos analisando quando, falando sobre isso Agostinho afirma que "é a luz, que se difunde primeiro somente por meio dos olhos e brilha nos raios dos olhos para ver as coisas visíveis". Este tema da capacidade dos olhos em ver as coisas que não estão em contato com os sentidos 
já aparece também no De quantitate animae I, xiii, 43 onde ali se argumenta a favor da capacidade dos sentidos de terem sensação sem que o objeto visto tenha um contato imediato com o sentido, o que de certo modo não contraria o presente texto, já que a luz, no caso aqui de Gn. litt não toca os olhos, mas, os olhos que emitem certa luz que se projeta em direção às coisas que estão fora do corpo. ${ }^{121}$

Já em De gen. ad litt. III, iv, 6-v, 7 temos uma exposição mais longa e precisa sobre o tema que estamos estudando. No § 6, Agostinho, após uma exposição acerca da relação entre os quatro elementos da natureza e os cinco sentidos, fala em $\S 7$ do elemento mais sutil na natureza, e, portanto, mais espiritual. A pesquisa em busca desse elemento possui relevância na medida em que, a alma que é incorpórea, para sentir, deve valer-se de um corpo sutil para pode estimular a sensação. Ou seja, a alma vale-se do elemento corpóreo mais sutil, para que, agindo sobre esse possa mediar a sensação.

Os quatro elementos são o fogo, o ar, a água e terra, sendo que, cada sentido relacionase mais com um dos elementos ou certas variações ou combinações entre esses elementos, por exemplo, os olhos se relacionariam com o fogo, os ouvidos com o ar, o olfato e o paladar com a umidade e o tato se adequaria mais aos elementos terrenos. Dentre esses elementos, o fogo é quem penetraria em todos os outros elementos e corpos para produzir o movimento. Por exemplo, sem o fogo a água se congelaria com a falta de calor. Outro exemplo é que não poderíamos ver algo sem ele. Assim, para Agostinho, a alma, dentre todos esses, dá início ao movimento em todos os sentidos pelo fogo, que seria o mais sutil de todos os elementos, e que tudo penetra, justamente por causa de sua sutileza. Isso se dá como se segue:

Quando suprimido, o fogo se torna a luz no sentido da visão. No caso da audição o ar é purificado pelo calor do fogo; no olfato o ar puro passa até ganhar certa umidade a fim de ser exalado; no paladar esse ar também ganha uma umidade, no entanto, uma umidade maior que a do olfato tornando-se assim sabor. Finalmente no caso do tato, a umidade ainda mais avolumada estimula este sentido a ter contato com a terra:

[...] a alma, à qual é inerente a potência do sentir, não sendo corpórea, estimula a potência do sentir por um corpo mais sutil. Dá início ao movimento em todos os sentidos pela sutileza do fogo, mas não alcança o mesmo em todos. Na vista, reprimindo o calor, chega até à sua luz. ${ }^{122}$ No ouvido, penetra até o ar mais puro pelo calor do fogo. E no olfato, passa o ar puro e chega à exalação úmida, de onde se forma esse ar mais denso, no

\footnotetext{
${ }^{121} \mathrm{O}$ texto não dá nenhum indício que o processo seja reflexivo, como se a luz exterior tocasse no olho e depois do olho se dirigisse à coisa exterior a ser vista, na verdade a luz se difunde por meio dos olhos para as coisas exteriores.

${ }^{122}$ Os negritos são meus.
} 
paladar, passa a este ar e chega à umidade mais avolumada, a qual, penetrada e atravessada, estimula o último dos sentidos, o tato, a chegar à gravidade da terra. $^{123}$

Toda essa descrição encontrada nesses dois parágrafos serve para mostrar que o fogo está presente nas sensações de todos os cinco sentidos. Ora, se pensarmos que o fogo está mais presente na luz, e esta por sua vez pertence ao sentido da visão, logo temos aí justificada a superioridade da visão sobre as outras sensações. Entretanto, essa análise ainda parece insuficiente para responder à questão da superioridade temporal ou não da visão. Por isso, devemos ainda nos dirigir aos últimos trechos que tratam sobre esse tema em busca de algum esclarecimento.

Gn. litt. VII, xiii, 20 é primeiramente uma descrição mecanicista acerca do funcionamento do corpo humano. Tal descrição segue a descoberta do sistema nervoso por Hierophilus (330-260 a.C) que associa a respiração com o sistema nervoso, e dentro outros fenômenos, o sistema vascular como exposto por Eristratus de Ceos. ${ }^{124}$

Nessa exposição Agostinho explica que nosso corpo, mesmo possuindo solidez, guarda ar nos pulmões que se difunde do coração para as artérias. $\mathrm{O}$ corpo também possui fogo que tem a qualidade de calor e luz. A sede desse fogo está no fígado. Destes elementos, a luz destila-se e eleva-se para a parte mais alta do cérebro como o céu de nosso corpo. Daí sai então os raios dos olhos. Essa luz ou raios são conduzidos por meio de tênues condutos para todos os sentidos, os quais permitem a operação dos cinco sentidos. Isso se dirige do cérebro para a coluna cervical e daí para todo o corpo em suas finíssimas ramificações para ativar o sentido do tato. ${ }^{125}$

123 “ [...] anima tamen cui sentiendi vis inest, cum corporea non sit, per subtilius corpus agitat vigorem sentiendi. Inchoat itaque motum in omnibus sensibus a subtilitate ignis, sed non in omnibus ad idem pervenit. In visu enim pervenit represso calore usque ad eius lucem. In auditu usque ad liquidiorem aerem calore ignis penetrat. In olfactu autem transit aerem purum, et pervenit ad humidam exhalationem, unde crassior haec aura subsistit. In gustatu et hanc transit, et pervenit usque ad humorem corpulentiorem: quo etiam penetrato atque traiecto, cum ad terrenam gravitatem pervenit, tangendi ultimum sensum agit. ”(De gen. ad. litt. III, v, 7)

${ }^{124}$ Uma exposição mais completa sobre esse ponto e sua apropriação por Agostinho ver O’DALY, The responde to skepticism and the mechanisms of cognition p.164-170 in STUMP, Eleonore; KRETZMAN, Norman (Eds.). The Cambridge companion to Augustine. Thirf printing. Cambridge; New York; Port Melbourne; Madrid; Cape Town: Cambridge University Press, 2004.

125 "Deinde si non est contemnendum quod medici non tantum dicunt, verum etiam probare se affirmant, quamvis omnis caro terrenam soliditatem in promptu gerat, habet tamen in se et aeris aliquid, quod et pulmonibus continetur, et a corde per venas, quas arterias vocant, diffunditur; et ignis non solum fervidam qualitatem, cuius sedes in iecore est, verum etiam luculentam, quam velut eliquari ac subvolare ostendunt in excelsum cerebri locum, tamquam in coelum corporis nostri; unde et radii emicant oculorum, et de cuius medio velut centro quodam, non solum ad oculos, sed etiam ad sensus caeteros tenues fistulae deducuntur, ad aures scilicet, ad nares, ad palatum, propter audiendum, olfaciendum, atque gustandum; ipsumque tangendi sensum qui per totum corpus est, ab eodem cerebro dirigi per medullam cervicis, et eam quae continetur ossibus, quibus dorsi spina conseritur, ut inde se tenuissimi quidam rivuli, qui tangendi sensum faciunt, per cuncta membra diffundant." 
No que toca à nossa investigação, algumas coisas parecem ficar muito claras depois dessa exposição. Em primeiro lugar, fica confirmado o primado temporal do sentido da visão sobre os outros sentidos no fato de que, a luz que está no cérebro se distribuí primeiramente para os olhos que são o órgão corporal do sentido da visão. Depois, imediatamente decorre a partir disso e do texto e de De gen. ad. litt. XII, xvi, 32 uma superioridade hierárquica, pois foi mostrada a superioridade da luz sobre os outros elementos, já que o sentido que recebe a luz também possui uma superioridade sobre os outros pelo fato de que só o sentido da visão capta a luz em sua inteireza e sutileza sem estar composta com o ar como nos outros sentidos.

Entretanto, esse processo fisiológico não deve nos enganar a ponto de pensarmos em Agostinho como um mecanicista. Na verdade, todo o processo depende da ação da alma sobre os elementos corpóreos ${ }^{126}$, no entanto, essa ação não pode ser exercida sobre um corpo qualquer, existe a obediência a uma hierarquia:

Contudo, a alma, porque é uma realidade incorpórea, age primeiramente no corpo que é mais próximo ao incorpóreo, como é o fogo ou, antes, a luz e o ar, e, por meio desses, agem os demais que são os mais densos do corpo. ${ }^{127}$

Assim, podemos concluir que Agostinho se apropria da explicação mecanicista que colocava a luz como o elemento corpóreo que estava no cérebro e se expandia pela visão e para os outros sentidos ${ }^{128}$ para afirmar que isso mostra apenas que a alma age por meio dos elementos mais sutis e que estariam mais próximos do incorpóreo, a luz e o ar. O mecanismo da sensação tal como explicado por Agostinho a partir de Hierophilus e Eristratus de Ceos, longe de excluir o papel da alma no processo sensitivo ou relativizá-la, na verdade serve para fundamentá-lo. Agostinho se apropria de uma explicação mecanicista para relativizá-la e retomá-la em chave neoplatônica.

${ }^{126}$ Logo no início do capítulo seguinte Agostinho faz questão de afirmar que a alma recebe as informações exteriores por meios desses mensageiros: "Cum igitur his quasi nuntiis accipiat anima quidquid eam corporalium non latet” (De gen. ad litt. VII, xiii, 21). Ou seja, todo esse sistema fisiológico não é independente em si mesmo, sem a alma ele não existe.

127 "anima ergo quoniam res est incorporea, corpus quod incorporeo uicinum est, sicut est ignis, uel potius lux et aer, primitus agit, et per haec caetera quae crassiora sunt coporis" (De gen. ad litt. VII, xv, 21).

${ }^{128}$ Nesse aspecto, Agostinho parece partilhar da concepção de Plotino que, segundo Morel, ao comentar as Enn. IV, 7 [2], 7.7 ss “[...] não abandona totalmente a ideia mesma de uma transmissão interna das informações sensoriais entre os órgãos sensoriais e uma faculdade dominante. Aí ele é fiel ao Timeu e retoma, ao menos parcialmente, as conclusões de Galeno sobre os nervos, situando seu ponto de partida no cérebro. Plotino, todavia corrige a si próprio: o órgão não é senão um ponto de apoio, um instrumento e não o lugar da razão. A centralização encefálica não lhe serve fundamentalmente senão para manter a tese da unidade da sensação, a fim de não colocar em perigo a da presença não espacial da alma na totalidade do corpo, ou mais precisamente a da presença da alma no corpo. De resto, ele é muito evasivo sobre o processo físico em si mesmo e, se admite uma forma de transmissão interna, ele não a funda sobre uma teoria digna desse nome.” (2002, p.218). Tradução nossa. 
Além disso, mais um elemento ambíguo sobre a sensação aparece aqui. Como vista no De gen. ad litt., a sensação, apesar de ser uma ação da alma, parece, ao menos de modo geral, não ser uma ação do sentido sobre o sentido corporal em si mesmo, mas sobre o elemento corpóreo sutil que utiliza os sentidos corporais como mediadores. Ou seja, existe uma mediação que ainda não fora, no mínimo, explicitada em De quantitate animae.

Com a última afirmação adentramos na questão acerca da comunicação das substâncias. Parece que aqui há uma recuperação do tema por Agostinho que no De animae quantitate tratou da sensação apenas em seu voltar-se à modificação do corpo, mas sem detalhar esse processo. Dentro de uma filosofia das hierarquias como é o caso da sua, ainda ficara o ponto da mediação entre a alma e os corpos. O De Genesi ad litteram parece amarrar esse fio solto explicando como se dá a mediação entre incorpóreo e corpóreo: ela é feita pela atuação da alma, que, utilizando-se dos sentidos corpóreos, age sobre elementos corpóreos sutilíssimos que se aproximam dela; a reunião de tais elementos pode ser compreendida como sensação.

Em suma, temos dois ganhos teóricos nessa análise do sentido da visão: proeminência temporal e hierárquica da visão sobre os outros sentidos; os sentidos, por se referirem a ela, em última instância, nos leva a possibilidade de aplicar-lhe o título de uisio corporis como se referindo a toda sensação. O segundo ganho, menos esperado, foi o da afirmação da sensação como actus animi, entretanto, explicada pela comunicação das substâncias dentro de um processo hierárquico. Quanto à afirmação da sensação como atividade anímica, tentemos entender esse ponto a partir da relação entre o De trinitate e o De genesi ad litteram onde poderemos rever novamente as questões acima levantadas acerca da prioridade da alma e a intermediação dos sentidos como elementos passivos no processo sensitivo. Contudo essa compreensão acontecerá em outro registro, na uisio corporalis, ao levar em consideração um elemento ainda não explorado na exposição anterior: a specie.

\subsection{A Sensação como Atividade Anímica}

O que vem a seguir leva em consideração o que a nossa investigação tem alcançado até agora, em especial o ganho principal da seção anterior em que, ao investigar o sentido da visão, parece ter ficado claro que a sensação é uma atividade da alma. O que resta então a seguir? A nosso ver ainda não foram esclarecidos alguns problemas envolvidos no ato da sensação: como considerar a relação entre alma e corpo na sensação? A seção anterior procurou estabelecer uma mediação entre o objeto da sensação e a alma que sente por meio 
dos sentidos que por sua vez precisam de elementos corpóreos sutilíssimos. Toda essa hierarquia entre a alma e o corpo ainda parece não ser suficiente para pensar na relação entre alma e corpo, pois os corpos sutilíssimos ainda são corpos, contudo, a análise do De trinitate parece dar um passo além na explicitação do problema: certamente as species já se encontram num nível não corpóreo superior ao corpo, e assim, ao que parece, sendo mais apropriadas para pensar a relação de mediação entre a alma e o objeto visto. Contudo, para adentrar com propriedade nesse problema devemos nos deter sobre a questão da enformação dos sentidos.

Em Trin. XI, ii, 3 o conceito de "enformação do sentido" parece indicar uma atividade do sentido na sensação. Gilson, por sua vez, fala de uma informação no olho pela forma do objeto. ${ }^{129}$ Nesse caso, duas coisas devem ser notadas. Primeiro, ao pensar em tal enformação devemos lembrar que para Agostinho os sentidos são instrumentos do corpo; o que já nos leva à segunda consideração: o corpo, o órgão corporal, é animado. Portanto, a "ação" do objeto se dá sobre um órgão corporal animado. Vejamos cada um desses elementos.

\subsubsection{Os Sentidos como Instrumentos da Alma}

Já no começo do livro XI o Hiponense toca nesse problema, afirmando que [...] é pelos sentidos do corpo, de que o homem exterior é dotado, que sente os corpos...” (sensu [...] corporis exterior homo praeditus sentit corpora) trin. XI, i, 1.

O termo sensu, no caso ablativo já indica instrumentalidade. Essa característica de instrumentalidade, como veremos, é recorrente nos textos Agostinianos. Eis outras duas passagens do próprio De trinitate, onde os sentidos aparecem na forma passiva e que são instrutivas pela relação que têm com outros aspectos que merecem ser distinguidos da sensação. Uma se encontra em IX, vi, 10 e a outra XV, xii, 21. Eis a primeira:

[...] as imagens das coisas corporais absorvidas pelos sentidos do corpo e como que infundidas na memória, a partir das quais são pensadas com a mediação de sugestões imaginárias, as coisas que não foram vistas, diferentes do que são ou ocasionalmente tais como são, sejamos levados a aprová-las ou desaprová-las, quando em reto juízo as aprovamos ou desaprovamos em função de regras completamente diversas que se mantêm imutáveis acima de nossa mente. ${ }^{130}$

129 “a visão corporal, na qual o olho é informado (formatur) pela forma (species) do objeto" (2006, p.120, nota 3$)$.

130 "[...] phantasias rerum corporalium per corporis sensum haustas et quodam modo infusas memoriae, ex quibus etiam ae quae non uisa sunt ficto phantasmate cogitantur siue aliter quam sunt siue fortuito sicuti sunt, aliis omnino regulis supra mentem nostram incommutabiliter manentibus uel approbare apud nosmetipsos uel improbare conuincimur cum recte aliquid approbamus aut improbamus." 
Esse trecho mostra todo um processo de juízo que se volta para as imagens das coisas, colhidas pelos sentidos, ou criadas pelo pensamento, a cogitatio. Antes de se chegar ao juízo, se parte da atividade sensitiva que colhe phantasiae, ou seja, imagens das coisas corporais, para depois passar ao ato de pensamento, ou seja, da cogitatio que, por sua vez, formula as phantasmata, que são imagens distintas das phantasiae. Estas phantasiae são uma espécie de reprodução das imagens que estão nas coisas e nos sentidos de quem vê. Depois de guardadas na memória, tais imagens podem ser manipuladas pela visão interior que tem a capacidade de formular phantasmata ${ }^{131}$, ou seja, imagens que não são "cópias" imagéticas das coisas, mas imagens criadas a partir dessas imagens fiéis aos corpos. Para se definir qual dessas imagens é verdadeira ou não, a mente acessa regras imutáveis que possibilitam ao ser humano fazer um juízo ${ }^{132}$ de verdade ou falsidade acerca das mesmas. ${ }^{133} \mathrm{O}$ fato é que todo esse processo não pode existir se não existir primeiro uma absorção das imagens por meio dos sentidos do corpo. Assim, a sensação existe na medida em que os sentidos do corpo mediam a absorção dos elementos corporais exteriores a eles. Desse modo as imagens são absorvidas pelos sentidos corporais (per corporis sensum haustas).

O processo inicial de coleta das imagens no De trinitate insere-se num registro distinto da juventude de Agostinho. Por exemplo, no De quantitate animae, que nos serve de referencial, a questão está concentrada essencialmente sobre a atividade da alma como aquela que não deixa escapar uma paixão que o corpo sofre, ${ }^{134}$ entretanto, nada se fala sobre o processo pelo qual se dá a percepção da paixão; claro, faltava ali o elemento do objeto da

${ }^{131}$ Os termos phantasia e phantasma possuem, de modo geral, um sentido mais definido na filosofia Agostiniana. Para Etienne Gilson, “A imagem conservada pelo pensamento na memória denomina-se similitudo, imago ou, no sentido próprio phantasia. Uma imagem composta arbitrariamente formada para representar os objetos não percebidos chama-se phantasma" (2006, p.120 nota 3). O’Daly, por exemplo, dedica um tópico inteiro chamado Terminology: phantasia and phantasma (p.106-107) para explicar o termo phantasia. Segundo ele, para Agostinho, o termo phantasia é uma representação reprodutiva da imaginação, diferente do conceito estóico que considerava a phantasia como uma forma de impressão ou alteração na mente por meio de um objeto percebido, enquanto phantasma seria o produto de uma "atração vazia", ou "aparência das coisas" sem que houvesse uma causa externa na mente, exemplos de phantasma seriam as imagens dos sonhos ou alucinações. Ainda segundo O’Daly, Porfírio pode ter adaptado a distinção estóica e influenciado Agostinho. Para Porfírio a phantasia é a faculdade que forma imagens dos objetos externos. Entretanto Agostinho usa esse termo se referindo às faculdades mentais ou processos mentais bem como o que resulta desses processos, mas usa também predominantemente no sentido de imagem ou impressão. No caso do phantasma ou dos phantasmata, eles em geral se referem à formação de imagens a partir das imagens guardadas na memória. Em De mus. VI, xi, 32 a produção dos phantasmata se dá quando a intentio se volta às imagens na memória produzindo imagem a partir de imagens, entretanto, Agostinho explica que aqui a adoção do termo é convencional.

${ }^{132}$ Segundo a análise de Bubacz, este texto fala que existem modelos que estão a disposição da mente para ordenar experiências, mas em nenhum momento ele trabalha o elemento judicativo que parece explicito aqui: "The consistent set of beliefs that structure previous experiences and mold future experiences results from this utility and the physical element in experience." (1981, p.116).

${ }^{133}$ Aqui não temos o propósito de detalhar esse processo juducativo, entretanto, no que toca à cogitatio, ela será analisada já que faz parte do livro XI do De trinitate.

${ }^{134}$ Explicar aqui o essencial do processo no De animae... 
sensação ser precisado. Esse elemento unido aos sentidos e à sensação será visto com mais propriedade à frente. Por ora, continuemos a presente análise, agora em mais um trecho do $D e$ trinitate que se encontra no livro $\mathrm{XV}$, xii, 21.

Nesse parágrafo, em primeiro lugar se fala de coisas que chegam à alma por meio dos sentidos do corpo [quae in animum ueniunt a sensibus corporis], e mais a frente que:

Como são dois os gêneros de coisas que se sabem: um o daquelas que a alma percebe por meio dos sentidos do corpo, outro o daquelas que sabe (percebe) por si mesmo, muito tagarelaram esses filósofos contra os sentidos do corpo [...] Mas longe de duvidarmos que as coisas que aprendemos por meio dos sentidos do corpo são verdadeiras. Por meio deles aprendemos que existem o céu e a terra e aquelas coisas que neles são conhecidas por nós na medida em

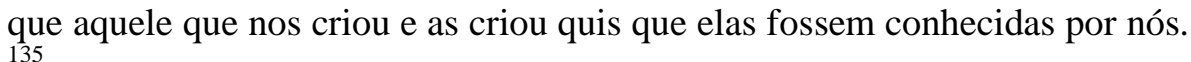

Essa afirmação se insere dentro da polêmica cética em relação aos sentidos. Entretanto, importa notar que Agostinho afirma a capacidade dos sentidos em lidar com os elementos corporais (céu e terra) criados. Esse "lidar" presente aqui, é um lidar com percepção. A composição da frase é complexa. Em primeiro lugar Agostinho afirma que são dois os tipos de coisas que se sabem [sciuntur], para em seguida afirmar que estes dois modos são, em primeiro lugar o daquelas que a alma percebe [percipit] por meio dos sentidos, e aquelas que são por si próprias [alterum earum quas per se ipsum].

No De quantitate animae parece ter ficado marcada uma distinção entre sensus e scientia. No caso da sensação, o verbo usado para indicá-la é percipio, enquanto no caso da scientia o verbo é scio. ${ }^{136}$ Ora, sciuntur é forma passiva de scio, portanto, etimologicamente poderíamos concluir que a sensação, ou percepção seria uma forma de conhecimento já que, em latim, o verbo percipere também pode ter sentido de conhecimento. No segundo modo de conhecimento temos as coisas que são por si próprias, mas "se próprias" o quê? Percebidas ou conhecidas? Se adotarmos a interpretação de que nesse contex to scio e percipio tem o mesmo sentido podemos traduzir por ambos os termos sem alteração fundamental do significado.

Uma possível solução poderia estar em dizer que o vocabulário de Agostinho não pretende ter uma precisão técnica, ele é relativo aos problemas que estão sendo abordados, ou seja, Agostinho procura usar o melhor vocábulo para tentar resolver o problema segundo a perspectiva em que está se tratando dele. No contexto do De quantitate animae, a ênfase de

135 "cum enim duo sint genera rerum quae sciuntur, unum earum quas per sensum corporis percipit animus, alterum earum quas per se ipsum, multa illi philosophi garrierunt contra corporis sensus [...] sed absit a nobis ut ea quae per sensus corporis didicimus uera esse dubitemus. per eos quippe didicimus caelum et terram et ea quae in eis nota sunt nobis quantum ille qui et nos et ipsa condidit innotescere nobis uoluit"

136 “[...] omne quod scimus, ratione scimus" (an. quant. I, xxix, 57) 
Agostinho se encontra num registro distinto daquele dessa passagem do De trinitate. No primeiro caso, Agostinho quer marcar claramente a distinção entre sensação e ciência, por isso, talvez a distinção seja feita de modo mais preciso, enquanto na passagem do De trinitate Agostinho, em polêmica com os céticos e acadêmicos, visa mostrar que a sensação está, ou na base do conhecimento, ou como ponto de partida do mesmo, ou tendo, em si mesma, alguma dimensão cognoscitiva. ${ }^{137}$ Contudo, esse não é o ponto principal nessa seção, pois aqui importa mostrar que os sentidos são uma espécie de junção entre órgãos corporais e a alma que anima esses mesmos sentidos. O uso do termo no ablativo e enfatizando a sua passividade não quer dizer passividade da alma, mas a passividade dos órgãos dos sentidos.

\subsubsection{A Alma que Sente é Superior ao Corpo.}

$\mathrm{Na}$ exposição desse tópico, por questões de clareza, veremos como Agostinho explicita esse problema no De Genesi ad litteram em conjunto com o De trinitate. A escolha dessa obra (que aparecerá novamente no presente trabalho outras vezes) justifica-se na medida em que sua composição é a mais próxima ao De trinitate. ${ }^{138}$ Basicamente em nossa exposição seguiremos o parágrafo 33 do livro XII.

Aqui vem à tona algo admirável, ou seja, como o espírito é primeiro em relação ao corpo, e a imagem do corpo é posterior ao corpo, contudo, aquilo que é posterior no tempo se forma no que é primeiro pela natureza, a imagem do corpo no espírito é mais excelente que o próprio corpo em sua substância. Não se há de pensar que o corpo faz algo no espírito, como se o espírito se submetesse ao corpo que age pela condição de ser matéria. Com efeito, de todos os modos é mais excelente o que faz do que a matéria da qual se faz algo. ${ }^{139}$

${ }^{137}$ Essa é a concepção de MacDonads que defende um voluntarismo cognitivo. Eis o que ele nos diz: "Following Augustine, I take sensory congnition to include sense perception, sensory memory, sensory imagination, and sensory thought - that is, perception, memory, imagination, and thought involvind bodies." (2012, p.235,236). Assim, todo o ato envolvendo a sensação e mesmo os movimentos interiores da segunda trindade exterior já são conhecimento. Segundo McDonads, no caso humano, isso é possível por causa da vontade: "The intentio or uoluntas explains the achievement of cognitive contacte between the perceiving subject and the perceived object" (ibid, p.240).

${ }^{138}$ Se pensarmos que a composição do De trinitate durou 20 anos, de por volta de 399 à 419/20, apesar de ter sofrido uma possível reformulação por causa do "furto" dos livros I à XII por volta de 416, e o De genesi ad litteram também ter sido iniciado entre 399 e 400, e, apesar de ser difícil determinar a data do encerramento de sua composição, podendo ter se encerrado entre 410-415, temos aí duas obras a bem dizer contemporâneas, talvez isso explique a proximidade conceitual de vários elementos que se encontram em ambas as obras, e, o que está apenas implicito em uma se explique na outra.

139 "Hic existit quiddam mirabili, ut, cum prior sit corpore spiritus et posterior corporis imago quam corpus tamen, quia illud, quod tempore posterius est, fit in eo, quod natura prius est, praestantior sit imago corporis in" 
Antes de qualquer coisa, devemos esclarecer que o termo "espírito", aqui traduzindo spiritus, está se referindo à alma em si, muito perto daquilo que é chamado de uisio spiritualis. Portanto, mesmo falando de espírito, na verdade estamos falando também da alma. 140

Aqui parece existir a ideia de que, o que tem primado ontológico, no caso, o que é primeiro pela natureza, é superior àquilo que se sucede dele no tempo, ou seja, a imagem formada na alma humana é posterior cronologicamente ao corpo do qual ela é formada. Sobre a alma que forma essa imagem não há dúvidas, é superior ao corpo, e de uma superioridade não cronológica, pois ambos, alma e corpo foram criados simultaneamente por Deus. Em segundo lugar temos, se aquilo que é posterior no tempo (a imagem na sensação visual) deve ser formado pela alma, então, a imagem do objeto corporal é posterior no tempo ao espírito ou alma (Observemos que o problema da sensação começa a se complexificar quando Agostinho insere a formação da imago no ato da sensação visual) e também ao corpo do qual é imagem, nesse caso, agora já não sabemos se ela é inferior ou superior ao corpo. Se pensarmos que a imagem do corpo não é corporal, então ela seria superior ao corpo, pois mais próxima do espírito. Isso se daria na medida em que, apesar de estar de certo modo no objeto ${ }^{141}$, no fim das contas, é formada no espírito; em outros termos, a imagem seria superior ao corpo enquanto imagem espiritual ou forma.

\subsection{O Papel da Specie na Sensação}

A specie é inserida no processo na medida em que exerce o papel fundamental de estabelecer, como frisamos acima, uma hierarquia entre spiritus e corpus que não podem ter um contato direto. Contudo, esse posicionamento poderia deixar o ser humano numa espécie de solipsismo. Tal conclusão não é possível por dois motivos: primeiro: apesar de não existir um contato direto, isso não quer dizer, evidentemente, que não exista um contato. Contudo, tal contato é feito por meio da specie; segundo: Agostinho não está interessado no problema do solipsismo, por mais que seja atraente tentarmos encontrá-lo no pensamento Agostiniano com o intuito de aproximá-lo dos modernos, não é esse tipo de discussão que entra em cena aqui, pois, a sua intenção não é negar a existência do mundo sensível externo e corpóreo, mas

${ }^{140} \mathrm{O}$ vocabulário de Agostingo é muito flutuante, e, em muitos casos, somente o o contexto pode determinar qual seria a melhor tradução do termo. O'Daly afirma que a terminologia Agostiniana do termo spiritus é frequentemente é identificado com anima ou mens: "Spiritus, itself is often identical is meaning with anima, though it can also be equated with mens" (1987, p.8). Esse parece ser o caso aqui.

141 "sed formam corporis quod uidemus et formam quae ab illa in sensu uidentis fit per eundem sensum non discernimus quoniam tanta coniunctio est ut non pateat discernendi locus" (trin. XI, ii, 3). Aqui forma deve ser entendida como sinônimo de specie. 
apenas garantir a superioridade hierárquica do superior em relação ao inferior, garantindo assim a ordem cosmológica do universo. Esses elementos ficam mais evidentes no texto a seguir:

\begin{abstract}
De modo algum o corpo é mais excelente que o espírito, pelo contrário, o espírito é mais excelente que o corpo de modo eminente. Portanto, ainda que vejamos primeiro algum corpo que antes não víamos, e em seguida comece a imagem do mesmo a estar no nosso espírito [...] contudo o corpo não produz a sua imagem no espírito, mas o próprio espírito a produz em si mesmo com rapidez admirável, a qual dista de modo inefável da lentidão do corpo. A imagem do corpo, logo que este for visto pelos olhos, forma-se no espírito de quem vê sem qualquer intervalo de tempo. ${ }^{142}$
\end{abstract}

Um elemento a mais a ser observado no trecho acima é que a sequência temporal, visão, corpo, imagem é mais didática que descritiva, pois no final das contas o que se vê é a imagem que está no corpo de modo que a imagem no corpo e no sentido da vista seja simultânea no ato da visão. Esse ponto aparece também na análise do De trinitate, onde há uma simultaneidade entre imagem do corpo no sentido e na coisa vista. Contudo, quando falamos da formação da imagem na alma/espírito quando do ato da sensação, o espírito tem uma primazia que ao que parece é mais ontológica que cronológica e temporal. Essa produção da imagem pela alma pode estar se referindo a animi intentio do De trinitate que tem como objetivo lá e aqui enfatizar o ato da alma/espírito sobre o que lhe é externo, seja corpo, seja imagem. Outro ponto que deve ser observado e enfatizado é aquela da fenomenologia da sensação onde a formação da imago dá-se na alma humana, o corpo ficando como mero intermediário, contudo toda a fenomenologia está situada num nível supra-corporal e sensível. Um notável paradoxo de que a sensação seja uma atividade espiritual e não corporal.

O exemplo inicial do cego e da attentio, podem nos ajudar de alguma forma aprofundar essas considerações, pois, no caso do cego, ele tem um órgão, que, devido estar danificado, impossibilita a ação da alma sobre o mesmo, e, por conseguinte, sobre o objeto, ainda que os objetos corporais estejam ao alcance da vista. Mas também, no caso daqueles que possuem o órgão corporal em boas condições soí acontecer que não vejam determinado objeto em sua frente, ainda que estejam com os olhos abertos. Isso acontece por que a vontade não está direcionada a esse objeto, ou seja, a animi intentio pode estar envolvida no ato de enformação na medida em que estar de olhos abertos não significa ter visão. Logo, se ter

142 "neque ullo modo spiritu praestantius est corpus, imno perspicuo modo spiritus corpore. quamuis ergo prius uideamus aliquod corpus, quod antea non uideramus, atque inde incipiat imago eius esse in spiritu nostro [...] tamen eandem eius imaginem non corpus in spiritu, sed ipse spiritus in se ipse facit celeritate mirabili, quae ineffabiliter longe est a corporis tarditate; cuius imago mox, ut oculis uisum fuerit, in spiritu uidentis nullius pucti temporalis interpositione formatur" (De gen. ad litt. XII, xvi, 33). 
visão é ter o sentido enformado pela imagem do objeto visto, tal enformação também precisa da atenção da alma, ou seja, não basta ter o objeto visto ou os sentidos. A questão da attentio animi é fundamental no processo.

Na continuidade da explicação do processo sensitivo, Agostinho se valerá de dois exemplos para esclarecer o problema. O do sinete sobre a água e do sinete sobre a cera. Nestes, mais que o exemplo do cego, podemos ver o que poderia ser considerada a enformação do sentido.

No argumento sinete sobre a cera, o ponto central parece estar no fato de que podemos entender a sensação como uma espécie de impressão sobre o corpo na qual o corpo não recebe a corporalidade do sinete em si, mas apenas uma imagem deste último. ${ }^{143}$ Entretanto, esse exemplo é deficiente na medida em que não reproduz com clareza suficiente o que se sucede na sensação, e isso fica claro quando ele usa o exemplo do sinete sobre a água.

No caso da aplicação do sinete sobre a água temos alguns elementos que ajudam a compreensão de problemas que o ato da sensação levanta. Nesse exemplo a imagem na água desaparece imediatamente quando o objeto é retirado. Dessa feita, só se sabe que a impressão estava lá por causa da memória e do raciocínio. Outro ponto importante a ser analisado é o de que existe aqui um nível que coloca a sensação não no âmbito da corporalidade, como era o caso da concepção estoica que via a sensação como o resultado da impressão do objeto externo sobre o corpo humano; o exemplo do sinete sobre a cera deixa espaços para a concepção estoica.

\subsubsection{Sensação e Cosmologia Corporalista no Estoicismo}

Apesar de Agostinho defender uma cosmologia de cunho mais intelectualista, ele não nega a corporeidade, mas também não reduz as realidades ontológicas ao corpóreo. Na sua época, a segunda filosofia era representada majoritariamente pelo estoicismo, enquanto a primeira, pelo platonismo, em especial na interpretação de Plotino, o que veio a ser chamado posteriormente de neoplatonismo.

O estoicismo se coloca num registro corporalista que vê toda a existência ontológica como corpórea. Aceitar essa parte do estoicismo seria solapar a ideia da sensação como

${ }^{143} \mathrm{O}$ exemplo da cera e do sinete é aristotélico e se encontra em De anima II, 12, 424a 17ss. Eis o que ele nos diz: "[...] é preciso compreender que o sentido é receptivo das formas sensíveis sem a matéria, assim como a cera recebe o sinal do sinete sem o ferro ou o ouro, e capta o sinal áureo ou férreo, mas não como ouro

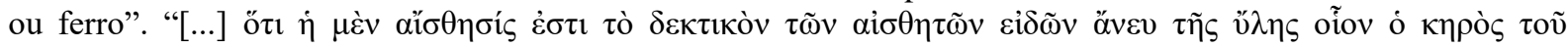

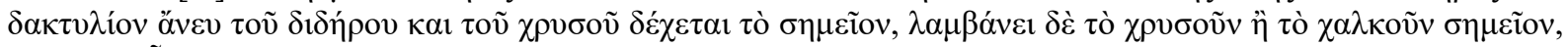

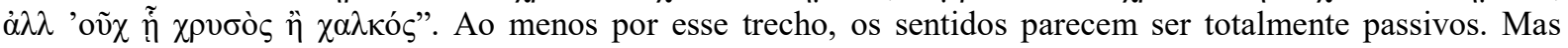
cumpre notar que o que eles recebem, assim como no caso de Agostinho, não é a própria materialidade da coisa, mas uma forma sensível. 
atividade da alma. Agostinho tem que se livrar de qualquer concepção que permita que alguma corporalidade do objeto da sensação chegue à alma. Admitir isso seria colocar o corpo ontologicamente acima da alma, o que ele não poderia aceitar.

Para os estoicos, tudo o que é real é corpóreo ${ }^{144}$. Gazolla resume isto muito bem ao dizer que "o estatuto do existente é o sensível, e o sensível é o que a alma capta por meio dos sentidos (que são também eles corpos), e estes, por sua vez, são penetrados de lógos hegemônico ${ }^{145 "}(1999$, p.117). Entretanto, já que a alma capta os sensíveis, por meio dos sentidos (que também são sensíveis) poderíamos perguntar: nesse caso, a alma não pode ser de uma ordem distinta do sensível? Sobre esse ponto Long esclarece que, segundo os estoicos o ser humano é composto de um corpo que é chamado de $\sigma \tilde{\omega} \mu \alpha$, no sentido de um corpo forte como o de Heracles, e também, de $\psi v \chi \eta ́$, ou seja, a alma, mas que também é uma espécie de corpo. ${ }^{146}$ Ainda o mesmo Long mostra que, para os estoicos, o próprio Deus possui corpo, pois têm as características corporais de massa, resistência e extensão espacial. ${ }^{147}$, sendo assim, não poderíamos pensar que no caso da alma humana seria diferente; inclusive Cleantes, mestre-escola do primeiro estoicismo, argumenta nesse sentido já tocando no problema da sensação. Segundo ele, os incorpóreos não participam do sofrimento de um corpo, o corpo visível claramente sente reações da alma que expressam esse contato entre os corpos, tais como a vermelhidão que se encontra nos corpos quando a alma está envergonhada e palidez quando está com medo, por exemplo. ${ }^{148}$

144 "nenhuma ideia está mais profundamente inculcada na filosofia estoica do que a convicção de que tudo o que é real é corpóreo" (HAMM apud WHITE, p.143). "Com efeito, os estoicos defendiam - nas palavras de Hamm - que, 'se o material consituinte de uma coisa é um corpo, a própria coisa é um corpo'. Ao que tudo indica, eles teriam feito uso desse princípio para concluir que as qualidades das coisas corpóreas são elas mesmas corpóreas" (ibid, p.145,146).

145 O hegemônico seria o que está ligado com o elemento reflexivo do lógos, sobre isso Brehier explica que "Os estoicos chamam de hegemônica ou diretriz da alma, e também reflexão, a esta parte onde se produz a representação, o assentimento e a inclinação; e a representam como um sopro ígneo localizado no coração. Dela emanam sete sopros ígneos: cinco se estendem até os órgãos (animando assim os cinco sentidos), de onde recebem as impressões sensíveis que transmitem ao centro" (1962, p.471). Assim, mesmo o hegemônico é visto como uma espécie de fogo, elemento muito sutil, mas ainda corpóreo. Vimos anteriormente essa discussão a propósito da descrição do processo sensitivo em Agostinho e como ele relê esse conceito em sua explicação que toma a alma como incorpórea.

146 "A human being, in Stoicism, is a composite of a $\sigma \tilde{\omega} \mu \alpha$, in the sense [...] of our saying that Heracles has a powerful body, and a $\psi v \chi \eta$ which is a body in some other sense. More specifically he is an ensouled, rational, and mortal body. More basically he is a part of the universal stock of matter (vँ $\lambda \eta)$ pervaded through and through by a part of god $(\theta \varepsilon \delta \varsigma)$; or alternatively, he is a part of god pervading some parto f the universal stock of matter" (LONG, 1982, p.36). "All things in the Stoic universe are combination of god and matter" (idem).

147 "God and matter together constitute something that not only has mass or resistance to pressure, and that is extended in space, but something which has shape or form" (LONG, 1982, p.37).

148 "Cleanthes' second argument is based on $\sigma 0 \mu \pi \alpha \dot{\theta} \theta \varepsilon 1 \alpha$ : "nothing incorporeal shares in the suffering of a body, nor does a body share in the suffering of an incorporeal; but soul suffers with the body when the body is sick and being cut, and the body suffers with the soul: the body turns red when the soul is ashamed and pale when the soul is afraid. therefore the soul is a body"' (LONG, 1982, p.42). 
Assim, da ideia de que tudo é corpo não seria de admirar que a sua concepção acerca da sensação seja também a de uma ação do corpo sobre os sentidos. Aqui entramos na famosa doutrina da impressão cataléptica.

\subsubsection{Sensação e Impressão Cataléptica no Estoicismo}

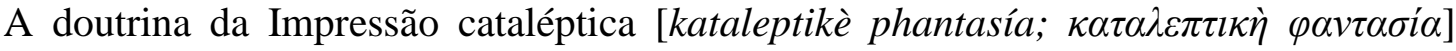
pode ser resumida da seguinte forma:

[...] existem dois tipos de impressão, uma cataléptica, a outra nãocataléptica: a cataléptica, que eles defendem ser critério para os fatos, é a que vem de algo existente e que está de acordo com a própria coisa existente, tendo sido esta estampada e impressa ( $\varepsilon v \alpha \sigma \varphi \rho \alpha \gamma l \varepsilon \mu \varepsilon \dot{v} v \dot{v} \kappa \alpha l$ $\varepsilon v \alpha \pi \circ \mu \varepsilon \mu \alpha \gamma \mu \varepsilon \dot{v} \eta \dot{v})$; já a não-cataléptica, ou vem de algo não existente ou, então, se vem de algo existente, não está de acordo com a coisa existente, e não é nem clara ('́v $\alpha \rho \gamma \eta \dot{\zeta})$, nem distinta". ${ }^{149}$

Os termos em gregos traduzidos por estampada e impressa são particípios compostos pelas preposições "غ̉ v" indicando aquilo que é colocado dentro e "ảjo" aquilo de onde é proveniente, o que sugere a localização interna da afecção e a sua origem externa.

Outro dado que é depreendido da citação acima é que a comunicação das substâncias é a garantia de verdade das percepções.

Segundo Hankinson, uma impressão cataléptica deve satisfazer as seguintes condições:

i. Deriva de um objeto existente

ii. Representa acuradamente esse objeto

iii. Está estampada e impressa nos órgãos sensoriais.

No caso da primeira e da segunda poderíamos em parte aceitar a primeira preposição, e totalmente a segunda. Mas o que interessa basicamente é o último processo, mesmo sabendo que sem os dois anteriores não é possível a impressão nos órgãos. Mas este processo pressupõe que existe uma identidade entre os órgãos sensoriais e essa "representação" do objeto.

No caso de "i”, não são consideradas catalépticas informações que homens loucos têm. No segundo caso, elas podem vir de objetos existentes, mas não representam o objeto. Exemplo disso é o caso do louco Orestes que supõe que sua irmã Electra seja uma das fúrias

149 (1: DL VII 46, = SVF 2.53, = 40C LS; cf. DL VII 49-51, SVF 2.52, 55, 61, = 39ª LS; M VII 248, = SVF 2.65, = 40E LS) Citado em HANKINSON, 2006, p.66. 
(ver Eurípedes, Orestes 256-64). No “iii", diz-se que todas as qualidades peculiares

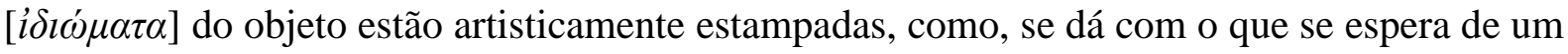
artesão. Mas em iii deve existir uma precisão que garante a distinção entre a impressão e a ficção, ou seja, um $\varphi \alpha ́ v \tau \alpha \sigma \mu \alpha$, uma suposição do pensamento.

\begin{abstract}
"Cícero posicionou a apreensão (comprehensio é o termo que Cícero usa para traduzir katálepsis) entre o conhecimento e a ignorância [...] sustentando que ela é por si mesma digna de confiança. Por essa razão, ele atribui confiabilidade aos sentidos, uma vez que, conforme afirmei acima, a apreensão produzida nos sentidos pareceu-lhe a um só tempo verdadeira e digna de confiança, não porque tudo apreendesse do objeto, mas por não omitir o que quer que pudesse contrastar com ela, e porque a natureza ". (HANKINSON, 2006, p.71).
\end{abstract}

Contudo, no estoicismo ainda não estamos no nível do conhecimento. A impressão cataléptica corresponde à sensação no pensamento agostiniano. Hankinson afirma que " $\mathrm{O}$ assentimento a uma impressão cataléptica [...] ainda não é conhecimento, que tem que ser mais estável e estruturado" (ibid, p.69). No entanto, essas impressões são fundamentais para se chegar ao conhecimento verdadeiro representando corretamente o objeto da mesma. Se a impressão é cataléptica então a mente lhe dá o assentimento:

“[...] a essas coisas, que são impressões e que são recebidas como que pelos sentidos, ele acrescenta o assentimento da mente, a qual ele defende que está dentro de nós e que é voluntária" (Acad. I, 40, = SVF 1.61, = 40B LS).

A esta colocação os céticos perguntavam: quando uma impressão cataléptica é satisfeita?

Um dos argumentos usados pelos acadêmicos contra os estoicos era o dos gêmeos idênticos. Tal argumento que afirma que diante da visão de dois gêmeos idênticos não existe nenhuma marca para discernir uma impressão verdadeira de uma impressão falsa. A isto os estoicos respondiam que não existem duas coisas absolutamente iguais, e que se observarmos bem, as impressões catalépticas representam acuradamente as características distintivas, ou seja, as $i \delta \imath \omega ́ \mu \alpha \tau \alpha$ do objeto: "os idiómatas particulares do objeto produzem diretamente o idioma do tipo de particular de impressão cataléptica" (HANKINSON, 2006, p.77).

Inútil se alongar nesse problema. Acreditamos que o exposto aqui é suficiente para entender que o posicionamento de Agostinho se coloca frontalmente contra a cosmologia e consequente teoria da sensação dos estoicos como fica mais claro a partir do exemplo do sinete sobre água. É hora de voltarmos a ele. 


\subsubsection{O Exemplo do Sinete sobre a Água e a Enformação do Sentido}

Apesar do exemplo do sinete sobre a cera poder refletir concepções como a estoica e a aristotélica, contudo, em Agostinho, ele serve a outros propósitos; uma coisa é pensar que a imagem é produzida pelo corpo visto, outra bem diferente é ser produzido através do corpo visto. ${ }^{150}$ Isso significa que o objeto corpóreo, no caso o órgão do sentido, recebe uma ação do objeto, mas, para falar numa linguagem que o De animae quantitate usa, essa é uma paixão sofrida, que, sem a animi intentio ou o non latens não pode ser dita sensação. Esse aspecto não pode ser ignorado sem mais, sendo de fundamental importância esclarecê-lo para prosseguirmos em nossas considerações.

\subsubsection{0 "non latens animam"}

Esse termo parece indicar que, existe a possibilidade de algo passar despercebido. Mas o que passaria despercebido? A presente análise se pautará no de animae quantitate, nossa obra de referência do pensamento inicial de Agostinho; o termo aparece lá. Segundo essa obra, o que não deve passar despercebido é o que o corpo sofre. ${ }^{151}$ Esse elemento aponta para o fato de que pode existir um sofrimento do corpo que não seja sensação. Claro, não há como pensar que o sofrer seja uma atividade. Esse é um problema filosófico notável, pois, se pensarmos com cuidado, é quase impossível pensar que num contato entre corpos não exista uma ação envolvida. Pensemos num caso simples onde um homem atinge outro com um soco. Nesse exemplo podemos inicialmente dizer que quem atinge o homem com um soco tem a sensação do impacto entre o punho dele e o corpo do outro homem atingido, entretanto, não podemos confundir o propósito ou vontade que o move a dar o soco, com a sensação: é o corpo no choque com outro corpo que sofre esse choque, mas é a atenção da alma sobre esse ato do murro que vai produzir a sensação. Mas e no caso do homem que leva o soco? Ele provavelmente está atento, mas e se estiver dormindo? É notável pensar a falta de sensibilidade que experimentamos quando estamos dormindo. Como explicar algo assim? ${ }^{152}$

150 "La comparaison du cachet de cire éclaire précisémenr ce point: si la bague laisse as forme dans la cire, celle-ci reçoit la forme de la bague, et non pas la bague elle-même, qui lui demeure toujours extérieure" (BERMON, 2001, p.244). Com isso concorda Matthews: "And since in this process, the sensation proceeds, not from that body which is seen, but from a living body that perceives, to which the soul is fitted together in some marvelous way of its own, yet the vision is produced by the body that is seen" $(2006, p .63)$.

151 "sensum puto esse, non latere animam quod patitur corpus" (an. quant. I, xxiii, 41).

152 O exemplo do "soco" não é agostiniano, é nosso e serve para levar as ultimas consequências a questão do não deixar passar despercebido. 
Ao que parece, o tema do non latens se liga ao da atenção da alma, mas, como não estar atento à dor, por exemplo? É possível isso sem "estar" morto?

Se considerarmos que a sensação é um ato da alma, então viver é inseparável de sentir, nesse caso, a sensação seria "uma função vital exercida pela alma no corpo e para seu benefício". ${ }^{153}$ Essa atenção vital se expressa essencialmente em dois aspectos, na doação da vida como um todo, e numa das expressões fundamentais da vida, a sensação. Vejamos cada uma delas

Quando fala de sentidos, Agostinho se refere aos sentidos capazes de sentir, portanto, o sentido animado. ${ }^{154}$ Esse ponto é desenvolvido em De quanitate animae I, xxx, 60, onde Agostinho afirma que um corpo pode sofrer uma ação externa ainda que a alma não esteja presente no corpo, ou seja, pode existir uma paixão corpórea sem alma, ou seja, sem sensação $^{155}$. Ora, isso mostra que o elemento passional dos sentidos não é sinônimo de sensação, como já frisamos; e aqui retomamos à nossa questão com mais precisão, pois, nesse exemplo, parece ficar claro que, uma coisa são os sentidos, outra a sensação. Isso é provado pela possibilidade de poder haver uma paixão, ou seja, uma ação corporal sobre outro corpo, sem que isso implique a sensação. Para que haja sensação, a alma deve estar presente e não pode deixar passar despercebido o que o corpo sofre como vimos acima. Assim, a faculdade de sentir não se refere simplesmente aos sentidos, mas aos sentidos animados à qual os homens compartilham com os animais (bestae) e que são evidências de que estão vivos. Portanto, temos então os sentidos animados. Mas então, ainda não respondemos a questão: é possível uma paixão passar despercebida sem que quem perceba essa sensação não esteja morto?

Agostinho dá a entender que a sensação tem a função de assegurar a sobrevivência, assim, quando uma paixão exterior é nociva ao corpo, impedindo-o de suas atividades comuns, a alma volta a sua atenção sobre essa paixão fazendo um esforço para descartar esse obstáculo para fazer o corpo animado voltar a funcionar como deve. Esse esforço produz, por

\footnotetext{
${ }^{153}$ A formula é de Etienne Gilson (2006, p.130).

${ }^{154}$ Isso não é tão obvio, pois, como já foi apontado acima, existe uma distinção entre sensação e sentidos. Ora, os sentidos apenas por si mesmos, ou seja, sem alma, não têm vida

155 "[...] et tamen talia pati oculus posset etiam in exanimo corpore, quamuis deeset anima, quam passio non lateret". Por isso talvez seja instrutio fazer uma distinção entre paixões da alma (ver BERMON, Emmanuel. A teoria das paixões em santo Agostinho, pp.199-242 in BESNIER, Bernard; MOREAU, PierreFraçois; RENAULT, Laurence. As paixões antigas e medievais: teorias e críticas das paixões. São Paulo: Loyola, 2008) e paixões corpóreas.
} 
exemplo, a sensação de dor. ${ }^{156}$ Este princípio se estende as outras sensações como bem explica Etienne Gilson (2001, p.131):

\begin{abstract}
A fome ou a sede não são diversas da atenção especialmente dada pela alma à falta de alimento ou bebida de que o corpo sofre momentaneamente. Se forem oferecidos para ele alimentos que reestabeleçam o equilíbrio corporal momentaneamente destruído pela necessidade, a alma mostrar-se-á atenta e a sensação que se sentirá será de prazer.
\end{abstract}

Em suma, a atenção [attentio] da alma visa não deixar passar despercebida nenhuma paixão sofrida pelo corpo ao que parece, com vistas a manter o seu funcionamento em ordem a fim de preservá-lo da morte. ${ }^{157}$

\title{
2.5.2.2. Preservação da Autonomia da Alma no problema da Enformação dos Sentidos
}

Até agora a alma está preservada de qualquer ação externa ou penetração de algum elemento externo a ela. Quanto ao sinete sobre a água, o ponto principal, é o da simultaneidade entre objeto visto e visão; a sensação se refere ao instante da presença do objeto e da visão, que, quando o objeto é retirado, a sensação também deixa de existir, que, ela só existe no exato momento em que se dá o encontro entre objeto visto e visão. O que parece existir aqui é a ausência de intervalo de tempo no ato da sensação. Ademais, a forma só está no sentido enquanto o objeto está presente à visão, quando o objeto é tirado ele desaparece assim como se dá com quando o sinete é retirado da água. A simultaneidade aqui pode comparecer para mostrar que na fenomenologia da sensação não existe uma passividade, o que se poderia pressupor quando existe um intervalo de tempo entre uma ação e outra na medida em que aquele que age está agindo sobre algo que ainda está passivo.

Ainda no exemplo da água, Agostinho esclarece que, removida a coisa, a forma não se mantém, assim como quando uma coisa que reflete na água é tirada de lá, a água (sentido) se

${ }^{156}$ Ver sobre esse ponto Gilson (2006, p.131) e mus. VI, v, 9: "Corporalia ergo quaecumque huic corpori ingeruntur aut obiiciuntur extrinsecus, non in anima. sed in ipso corpore aliquid faciunt, quod operi eius aut aduersatur, aut congruat. ideoque cum retinitur aduersanti, et materiam sibi subiectam in operis sui uias difficulter inpingit, fit attentior ex difficultate in actionem; quae difficultas propter attentionem cum eam non latet, sentire dicitur et hoc uocatur dolor aut labor".

157 Com esse ponto concorda Bubacz, por exemplo, ao menos indiretamente no que se refere às modificações externas ao corpo, nesse caso ele fala da visão que proporciona a capacidade de estar atento ao que se sucede no ambiente externo a fim de proteger o corpo animado dos perigos que podem lhe acometer (1981, pp.120,121). Já Gilson fala num sentido mais amplo. O texto que se segue é notável por precisão e concisão: “O non latet indica precisamente que a alma é uma força espiritual sempre vigilante e presente: para sentir, ela não tem que receber nada dos órgãos que vivifica, basta que as modificações sofridas por esses órgãos não escapem a ela e penetrem no campo de sua atenção" (2006, p.134). 
mantém, mas a forma (imagem do objeto no presente) não se mantém. ${ }^{158}$ Assim, o objeto gera "uma forma" ou a sua "semelhança" que está no sentido da vista. Ou seja, essa forma não é um elemento corporal.

Como tivemos ocasião de ver em De trin. XI, ii, 2, levantamos o problema da enformação do sentido pelo viés da distinção entre sentido da visão e objeto visto, esclarecendo que ambos eram, por natureza, distintos, e, dessa forma, não poderíamos conceber a ação do objeto no sentido, por que, se a alma é superior ao corpo, o sentido da visão que é animado é superior ao corpo visto que é inanimado.

Mas essa não foi a solução de Agostinho, ao menos explicitamente. Ele parece seguir então outra via, deslocando esse problema da distinção entre sentido e objeto sentido para a consideração da imagem como estando no objeto visto e considerada no sentido de quem vê. Essa interpretação se baseia no pressuposto encontrado em XI, ii, 2 que afirma que quando está ausente o corpo visto, a imagem no sentido da visão desaparece também. Ora, se a imagem só permanece na visão enquanto o corpo está presente a ela, podemos deduzir que existe uma espécie de comunicação de semelhante com o semelhante. Essa também é a concepção de O’Daly, que afirma: “This process indicates that, for Augustine, perception is the perception of like (semelhante) by like (semelhante)" (1987, p.96). ${ }^{159}$

A argumentação se fortalece na medida em que Agostinho faz questão de dizer que o objeto visto não gera o sentido:

[...] não podemos dizer que o objeto que é visto gera o sentido; mas gera uma forma ou a sua semelhança, que se produz no sentido da vista quando sentimos alguma coisa, vendo-a. 160

Os termos são usados de maneira cuidadosa por Agostinho. Quando ele fala do sentido, afirma que o objeto gera a forma, mas o sentido é quem produz a sensação por meio da forma, ou seja, não existe uma ação causal do objeto sobre os sentidos, e sim a geração de uma forma. Tal forma pretende estabelecer uma semelhança que se aproxima daquilo que a adere. Desse modo, fica garantida a autonomia da alma em relação ao objeto corpóreo, pois

${ }^{158}$ Observe que aqui não se está falando de forma no sentido de eidos, mas de uma espécie de formae.

${ }^{159}$ Não somente O’Daly, mas Bermon também, ao afirmar que o que é percebido não é a forma corporal mesma, mas uma semelhança incorporal da forma corporal, mesmo sendo empiricamente impossível distinguir a forma do corpo da forma no sentido (2001, p.243).

160 “....] non possumus quidem dicere quod sensum gignat res uisibilis; gignit tamen formam uelut similitudinem suam quae fit in sensu cum aliquid uidendo sentimus”. (trin. XI, ii, 3) 
não é corpo que é percebido ${ }^{161}$, mas uma forma desse corpo. Entretanto, cumpre notar que essa autonomia não excluí o corpo que é objeto da sensação do processo sensitivo. Aliás, Agostinho é claro em afirmar que "A visão é gerada, pois, a partir da coisa visível, mas não só dela, se não houver também quem veja". ${ }^{162}$ Assim, a sensação é a conjunção entre ato de ver e a geração da imagem pelo objeto. ${ }^{163}$ Apesar disso, já foi objetado que, o exemplo do sinete não é tão apropriado na medida em que, ao pé da letra, é um exemplo materialista, mas à isto também já se objetou que ele também pode ser compreendido como uma ação de um ser vivo sobre o corpo. ${ }^{164}$

Esse último ponto nos leva a pensar que a enformação dos sentidos se dá prioritariamente pela alma. O ponto fica claro a partir da citação acima que esclarece que a forma: “[...] se produz no sentido da vista quando sentimos alguma coisa, vendo-a". Ora, do texto depreendemos que a produção só pode se dar quando se tem a sensação da visão, que, como já esclarecemos é uma atividade da alma. Portanto, conclui-se que a enformação dos sentidos é também uma atividade anímica, sendo que é a alma que produz as formas não corporais das coisas vistas a partir de si mesma a partir do objeto externo visto.

161 "La forme perçue, ou la vision, est donc consubstatielle au sens et non pas au corps. Elle est une réalité incorporelle. Plus précisément, la vision est une modification du sens du vivant, c'est-a-dire une modification d'une realité à laquelle le corps extérieur demeure étranger et qu'il est incapable d'engendrer [...] si le corps extérieur engender la vision, c'est par la médiation de la réalité psychique qu'est le sens et qu'il est incapable d'engendrer lui-même" (BERMON, 2001, p.243). O sentido não é algo puramente exterior, como é o corpo, mas é uma realidade psiquica na medida em que é animado pela alma e governado pelo sentido interior como já tivemos ocasião de ver anteriormente. Para finalizar, "C'est porquoi Augustin répète à plusieurs reprises que ce que nous percevons, ce n'est pas le corps lui-même, mas la forme de ce corps dans le sens [...] Augustin s'éleve ainsi contre l'idée selon laquelle ce que nous voyons serait immédiatement le corps agit directement sur um autre, sans la médiation du sens, qui est le fait du vivant et dans lequel se forme la vision. L'idée est pourtant d'autant plus prégnante qu'elle semble trouver une confirmation dans le fait que, lorque le corps n'est plus là, la vision disparaît" (idem).

162 "gignitur ergo ex re uisibili uisio, sed non ex sola nisi adsit et uidens" (idem).

163 Diante do que observamos até agora, Gignitur não pode ser tomado aqui no sentido de atividade causal é claro, mas como uma espécie de participação do objeto visto na produção final da sensação. Uma leitura de Bermon pode levar a uma compreensão causal do objeto, vejamos o que ele afirma: "Augustin fait donc de la perception sensible l'acte commun du sentant et du senti, à le êxemple meme d'Aristotle qui affirmait que, dans la perception, 'l'acte du sensible et l'acte du sentant constituent un seul acte, bien que leur essence soit

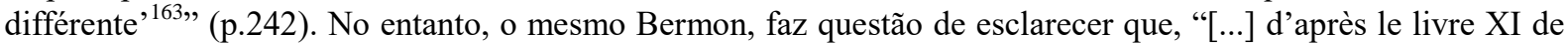
la Trinité, le corps jouit du privilège d'engendrer (gignere) la vision, il apparaît clairement dans ce texte que'engendrer, ce n'est pas produire ou faire (facere). Si la naissance de la perception est le fait et du corps et du vivant, c'est le vivant lui-même qui détient le rôle hégémonique dans ce processus" (Idem, p.246).

164 É esse o pensamento de Bermon: "Em effet, prise à la lettre, elle semble être um modèle d'explication matérialiste de la perception" (p.244). Mas o mesmo Bermon defende que, Agostinho se serve dessa imagem para se afastar de toda interpretação materialista da percepção do corpo: "La comparaison du cachet de cire doit permettre de montrer que la perception n'est pas une perception du corps lui-même, tel qu'il existe comme être corporel composé d'une matère et d'une forme, ni même de quelque chose du corps, comme des efflluves qui émaneirainent de lui, mais perception de ce qu'Aristote appelle la 'forme' même du corps, séparée de la matière, et Augustin as 'ressemblance' ou son 'image', qui est une certaine formation du sens. Une telle formation est, pour Augustin, une réalité psychique ou vivant, que le corps est impuissant à engendrer comme telle, puisqu'il n'engendre pas le sens" - ou seja, contra uma teoria corporalista da ação do objeto externo sobre o sentido, temos uma formação da imagem pelo sentido. 


\subsection{Vontade e Conhecimento na Sensação?}

Agostinho não é um filósofo sistemático como, por exemplo, São Tomás de Aquino e Hegel. Esse aspecto de sua filosofia é importante na medida em que lhe permite uma investigação mais livre acerca dos problemas levantados. Contudo, para o historiador da filosofia esse aspecto traz dificuldades para a exposição do pensamento do autor, que, em geral se dá de forma sistemática.

No presente caso para uma compreensão mais plena temos tentado tematizar a exposição de Agostinho acerca da sensação, contudo, não se dificuldades, justamente porque vários problemas se interligam no pensamento do hiponense. Um exemplo disso é o tema dessa seção.

Em seções anteriores já abordamos indiretamente tanto a questão da vontade como a do conhecimento, contudo, por razões didáticas achamos melhor expô-las separadamente dos problemas que estavam sendo tratados no momento já que o objetivo é mostrar todas as nuances e características da sensação; um dos aspectos mais importantes nesse sentido é destacar as relações entre sensação, conhecimento e vontade. Por essa razão, consideramos relevante dedicar um tópico especificamente para tratar dessa relação. Portanto, o que vai a seguir é um ataque mais profundo ao problema. O que tentaremos mostrar é que a sensação humana, se não é conhecimento é, de alguma forma acompanhada por ele já que, quem tem a sensação é alma, e a alma é uma vontade racional.

\subsubsection{O Papel da Vontade na Sensação}

Pensar na vontade como condicionante central da percepção sensível, nos dá uma nova perspectiva sobre o problema, pois fortalece a tese da sensação como atividade anímica. Mas agora, chegamos perto do desdobramento do presente trabalho ao esclarecer os problemas já propostos acerca do tipo de conhecimento envolvido na sensação.

No ato sensitivo, é primordial a consideração da vontade como "força unitiva" (uis copulandi) que "isola um objeto sensível no campo perceptivo ao ligar a ele o sentido concernido (no caso analisado em De trinitate XI o sentido da visão) ${ }^{165 ”, ~(K O C H, ~ 2010, ~}$ p.75). Contudo, tal ato sensitivo não se dá automaticamente. Na medida em que estamos diante de uma serie de coisas exteriores percebemos que não temos a percepção de tudo aquilo que está diante de nós: algumas coisas nos escapam e outras não. É a vontade que

${ }^{165}$ Os parêntesis são meus. 
seleciona o que, mesmo estando sob os nossos sentidos, será ou não objeto de sensação. Dito de outro modo, não basta que exista um objeto externo e um sujeito que sente; além do objeto e do sujeito deve existir uma animi intentio, uma atenção da alma desse mesmo sujeito em relação ao objeto. Mas e como se dão as coisas na sensação animal? Será que o animal possui uma vontade?

Apesar de não tratar diretamente sobre a sensação, um trecho do texto citado acima de De trin. XII, ii, 2 ao falar sobre a cogitatio nos animais deixa entrever o que se poderia entender como "vontade" nos animais:

Também os animais irracionais podem não só sentir exteriormente, por meio dos sentidos do corpo, as coisas corpóreas, mas também recordar-se delas, uma vez fixadas na memória e desejar entre elas as que lhe são úteis e fugir das que não lhe convêm. ${ }^{166}$

O termo usado por Agostinho para se referir ao desejo que move os animais a se apropriarem das imagens na memória é appetere. Talvez o seu aparecimento aqui ao invés de uoluntas não seja apenas questão de estilo. Ora, Agostinho vem usando uoluntas para as atividades sensitivas e cogitativas humanas, porque agora se vale de outro termo?

Nas 83 questões diversas Agostinho afirma que "Amar não é senão desejar uma coisa por si mesma. [...] Na verdade o amor é uma espécie de desejo". ${ }^{167}$ No ser humano tal desejo pode ser considerado como um amor quando se deseja uma coisa por ela mesma. Em última instância somente Deus pode ser desejado por si mesmo. Mas no caso dos animais que não desejam a Deus, só desejam as coisas visando uma utilidade (conducibilia), não podemos considerar tal desejo como um amor. Logo, no homem esse appetitus quando direcionado a Deus é concebido como amor. Claro, também há a questão de que o desejo das coisas em si mesmas é a concupiscência, ou seja, um amor mal direcionado. Nos animais o appetitus é apenas um pendor natural, um instinto, uma inclinação; tal inclinação é considerada como um pondus, um peso, no caso humano tal peso é a uoluntas, no caso do animal apenas inclinação:

Não se trata de assimilar o movimento voluntário do espírito aos movimentos corpóreos [...] Com efeito, qualificar a vontade como peso permite assinalar que as criaturas corpóreas, ao 'tenderem' ao seu lugar natural, realizam um movimento que se assemelha ao dinamismo das

\footnotetext{
166 "possunt autem et pecora ete sentire per corporis sensus extrinsecus corporalia et ea memoria fixa reminisci atque in eis appetere conducibilia, fugere incommoda. uerum ea notare ac non solum naturaliter rapta".

167 (De diu. quaest. 83, qu. 35) "Nihil [...] aliud est amare, quam propter se ipsam rem aliquam appetere. [...] namquam amor appetitus quidam est".
} 
naturezas espirituais, estas sim, movendo-se voluntariamente rumo ao Princípio. [...] As criaturas, derivadamente, têm peso, mas apenas peso involuntário; o homem tem o privilégio de mover-se segundo a sua vontade, isto é, a sua vontade já é o seu movimento. (NOVAES, 1997, p. 60, 61).

Agostinho está inserido na tradição grega ${ }^{168}$ que relaciona o appetitus à őp $\xi_{i \varsigma}$ que, por sua vez, é apenas um desejo que conduz ao que está fora, não ao interior, de onde vem a independência das ações. ${ }^{169}$ Tal independência das ações já deve ser considerada como uoluntas, uma vontade livre que pode se direcionar de forma decisória, ou para o inferior ou para o superior. ${ }^{170}$ Assim, no animal o appetitus é ő $\rho \varepsilon \xi 1 \zeta$ enquanto no homem ele é identificado com a uoluntas.

Esclarecida, portanto, essa questão, podemos afirma que na sensação animal está presente um appetitus, mas não uma uoluntas; esta pertencendo apenas às criaturas espirituais, dentre as quais se encontra o homem.

Há uma implicação imediata dessa conclusão em nosso problema. Ora, se Agostinho faz questão de usar um termo para a atividade animal que não seja vontade, podemos concluir que existe uma distinção entre o modo de percepção humano e o animal. A attentio animi do ser humano nesse caso já é acompanhada de um discernimento que não acontece na percepção animal, pois o homem é dotado de racionalidade, e, mesmo que nem sempre ele esteja usando essa racionalidade, ela parece incidir sobre todas as suas atividades, incluindo a sensação. Sobre este aspecto Agostinho é claro: os animais são determinados pela utilidade [conducibilis]: o seu fim ao se direcionar às coisas corporais é sempre útil. Já o ser humano pode escolher, por meio da uoluntas, utilizar-se-á das coisas ou considera-las-á como um fim em si mesmas. No caso da sensação humana imediata o homem pode escolher, portanto, usando sua capacidade superior à dos animais para onde direcionará o movimento da sua vontade:

Mas se a vontade, que leva e traz de um para o outro lado o olhar a formar e, depois de formado, o une ao seu objeto, toda ela confluir na imagem interior e de todo desviar o olhar da alma da presença dos corpos que rodeiam os sentidos e dos próprios sentidos do corpo, e o voltar totalmente para a imagem que se vê no interior, observará que a semelhança da forma corpórea

168 “[...] Santo Agostinho pertence sem qualquer ruptura, à tradição de Platão e Aristóteles, passando por Plotino. Toda a terminologia do appetitus, em qualquer contexto, advém da tradição grega". (ARENDT, 1997, p.51 nota 22).

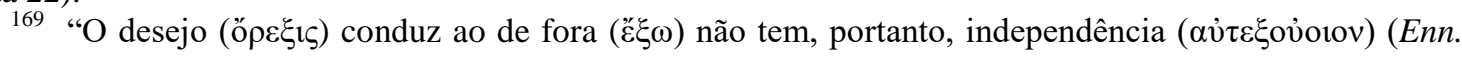
VI, 8, 4)”(ARENDT, 1997, p.47).

170 "Podemos dizer que a vontade ocupa lugar privilegiado na cosmologia agostiniana porque é ela o que distingue as naturezas espirituais, é ela que impulsiona o movimento, ou como inclinação para o inferior, ou como conversão para Deus". (NOVAES, 1997, p.59). 
tirada da memória é tão avassaladora que nem a própria razão consegue distinguir se é realmente um corpo que se vê exteriormente ou se é algo semelhante que é cogitado interiormente. ${ }^{171}$

Portanto, na sensação descrita estamos diante de uma inteligência voluntária ${ }^{172}$ Contudo, o problema pode ser mais bem esclarecido a partir do exemplo sobre a sensação da audição no De musica.

\subsubsection{Conhecimento na Sensação: Considerações a partir do De musica}

No sexto livro do De musica, Agostinho se detém numa análise mais aprofundada da sensação, contudo, diferente do De animae quantitate e do De trinitate nos quais o que está em foco é a sensação visual, agora se trata de considerar a sensação auditiva.

Para proceder a esta análise Agostinho propõe que se pense no que acontece quando ouvimos uma música. Como exemplo ele se servirá de um breve verso do hino de Ambrósio de Milão: “Deus creator omnium”. 173

Agostinho considerará que este verso possui 5 números ${ }^{174}$ distintos: $1^{\circ}$. Os números sonoros (sonantes); $2^{\circ}$. Os números ouvidos (occursores); $3^{\circ}$. Os números da memória (recordabilis). $4^{\circ}$. Os números pronunciados e, por último (progressores), $5^{\circ}$. Os números juízes (iudiciales) (mus. VI, vi, 16).

Agostinho se deterá longamente em uma reflexão sobre o lugar hierárquico que cada número ocupa em relação aos outros. Não é nosso propósito reproduzir ou tecer considerações sobre esse problema, senão na medida em que ele pode nos ajudar em nossa questão de

171 "uoluntas uero illa quae hac atque hac fert et refert aciem formandam coniungit formatam, si ad interiorem phantasiam tota confluxerit atque a praesentia corporum quae circumiacent sensibus atque ab ipsis sensibus corporis animi aciem omnino auerterit atque ad eam quae intus cernitur imaginem penitus conuerterit, tanta offunditur similitudo speciei corporalis expressa ex memoria ut nec ipsa ratio discernere sinatur utrum foris corpus ipsum uideatur na intus tale aliquid cogitetur"

${ }^{172}$ MacDonalds chama isso de voluntarismo cognitivo. "Following Augustine, I take sensory congnition to include sense perception, sensory memory, sensory imagination, and sensory thought - that is, perception, memory, imagination, and thought involvind bodies." (2012, p.235,236). Essa cognição é considerada então como um pensamento envolvendo os corpos.

173 "Deus criador de tudo" (De mus. VI, ii, 2).

${ }^{174}$ F.-J. Thonnard (1947) na nota 76 p.513,514 traz uma instrutiva síntese acerca do sentido do termo números tal como usado por Agostinho de Hipona. É um termo complexo que comporta várias acepções: "O termo numerus em santo Agostinho possui uma significação complexa e se pode marcar quatro etapas principais de suas aplicações: $1^{\circ}$. Primeiramente o sentido matemático ordinário de numero; assim é no De lib. arb. 1. II, viii, 20-23; $2^{\circ}$. No sentido de ritmo, seja musical, seja poético, como nos cinco primeiros livros do De musica; $3^{\circ}$. Ele se expande ainda e ganha o sentido de harmonia entre as diversas partes do movimento no mundo; e no homem, entre as diversas atividades sensíveis, intelectuais ou morais, é o caso, frequentemente no $\mathrm{VI}^{\circ}$ livro do De musica; $4^{\circ}$. Por último, em Deus, numerus significa a plenitude da unidade contendo virtualmente as leis matemáticas, a beleza dos ritmos, e todas as harmonias do mundo e do homem" (trad. nossa). Devido a esta polissemia do termo, utilizaremos a tradução portuguesa mais próxima ao latim, "número". 
aprofundar a problemática do conhecimento presente na sensação. Contudo, é importante conhecer do que estamos falando, por isso segue um breve resumo sobre cada um deles.

Basicamente podemos dizer que no primeiro tipo de número, temos o ritmo do som em seu ser físico, ou seja, o som em seu aspecto fenomênico. O som que está presente no ar que toca os nossos ouvidos é certamente corporal (mus. VI, iv, 7), por isso também devemos afirmar que esses números sonoros ou proferidos são corporais. $\mathrm{Na}$ medida em que eles atingem nossas orelhas excitam uma atenção da alma que se reproduz como um fato da consciência, nas sensações. Agostinho chama essas harmonias psicológicas de números ouvidos, estamos, portanto, no segundo gênero de números. Nesse ponto, ato imediato, por meio das sensações, esses ritmos se gravam na memória onde são conservados, mesmo na ausência dos sons reais, estes são chamados de números da memória.

Mas a alma pode também tomar a iniciativa e despertar os ritmos da memória ou combinar novos e em seguida retornar ao exterior para exprimi-los pela voz, o gesto ou um instrumento: agora estamos diante de um quarto tipo de número, os números proferidos. Por último a orelha possui uma aptidão inata para julgar a conveniência ou inconveniência dos diversos ritmos. Esta aptidão supõe um ritmo ou uma harmonia preexistente que serve como uma regra em suas apreciações: agora estamos diante de um número do julgamento, um número juiz. Contudo, devemos ainda pensar aqui num julgamento instintivo, que ainda é de ordem sensível e não necessariamente racional (mus VI, vii, 19), pois, acima de todos esses ritmos, reina a razão com suas próprias harmonias, participantes das divinas harmonias da sabedoria (mus.VI, ix, 24).

Considerando cada um das cinco classes de números, percebemos que a sensação dáse no segundo tipo, pois é nesse momento que temos as condições necessárias para tal: o som dos números sonoros que são corporais, portanto sensíveis; o sentido da audição juntamente com o órgão corporal das orelhas, e, por fim, a alma que capta tais sons e os produz em si mesma. ${ }^{175}$

No De musica, assim como o De animae quantitate e no De trinitate, Agostinho expõe também a ideia da sensação como ação da alma sobre o corpo. Mas isso não é tudo, vimos que na sensação está presente o non latens animam e a ideia de uma attentio animi. Contudo, aqui no De musica, Agostinho apresenta um curioso exemplo que parece minimizar a

${ }^{175}$ A alma não produz a sensação fora de si nos corpos e nem mesmo no sentido, mas evitando o solipscismo, deve-se sempre frisar a necessidades dos objetos exteriores no processo: "Sem dúvida, em certo sentido as sensações vêm do interior, mas, consideradas quanto ao seu conteúdo representativo, elas não contém nada que não chegue à alma senão pelo canal dos sentidos” (GILSON, 2006, p.157). 
amplitude desses dois aspectos que aparecem com clareza nas duas obras posteriores do Hiponense, o de uma sensação que parece dar-se sem que exista uma animi intentio:

[...] absorvidos muitas vezes por outro pensamento, nos parece não haver escutado a pessoas que estão falando em nossa presença. Não porque a alma não produza nesse instante números ouvidos quando o som chega sem dúvida aos nossos ouvidos e a alma não pode cessar de atuar na paixão do corpo, nem pode mover-se distintamente como se a paixão não existisse, mas por causa de sua atenção à outra coisa diversa, se extingue imediatamente a energia de seu movimento [...]. ${ }^{176}$

Este breve trecho a princípio parece contradizer a teoria do non latens animam do De animae quantitate e sua reafirmação por meio da attentio animi no De trinitate. Agostinho afirma a produção da sensação sem que seja necessariamente acompanhada de uma percepção: o uso do termo intenttione possui o mesmo sentido de attentio, de modo que a conversa parece passar despercebida (non latens) à alma. Por outro lado, Agostinho é claro em afirmar que a sensação auditiva produz-se mesmo assim: non quia occursores illos números non agit tunc anima. Como resolver esse impasse?

Penso em quatro possibilidades. A primeira seria a de que Agostinho não possui ainda uma teoria bem desenvolvida da atentio animi e do non latens animam. Contudo, essa possibilidade esbarra na exposição que Agostinho faz acerca da sensação em VI, v, 9,10. Ali ele desenvolve uma fenomenologia da sensação na qual esta é resultado de uma atenção (attentior) da alma para objetos corporais que se introduzem no corpo físico, favorecendo-o ou não. Dado esse elemento Agostinho trabalha a questão da intensidade de tal atenção quando afirma que "quando a alma sente no corpo, não sofre um influxo do corpo, mas atua com mais atenção (attentius agere) nas paixões do corpo [...] E tudo isto [...] é o que se chama sentir". ${ }^{177}$ Desse ponto se coloca a segunda possibilidade. Nessa hipótese postulamos que existe certa atenção da alma, ainda que fraca, sobre a sensação auditiva. Essa menor atenção se deve a concentração da alma e da vontade em outra coisa, no exemplo dado por Agostinho, o pensamento em algo qualquer. Ainda teríamos uma terceira hipótese que seria uma junção das duas primeiras, ou seja, Agostinho ainda não estaria de posse de uma teoria da sensação bem desenvolvida, mas já podemos ver os prenúncios da ideia de atentio animi e

\footnotetext{
176 "[...] plerumque alia cogitatione occupati coram loquentes non uobis uideamur audisse: non quia occursores illos números non agit tunc anima, cum sine dúbio sonus ad aures perueniat, et illa in passione corporis sui cessare non possit, nec possit nisi aliter moueri quam si illa non fierit; sed quia intentione in aliud subinde exstinguitur motionis impetus [...]". (mus. VI, viii, 20).

177 "[...] anima cum sentit in corpore, non ab illo aliquid pati, sed in eius passionibus attentius agere [...] et hoc [...] quod sentire dicitur". (mus. VI, v, 10)
} 
non latens. A quarta e última possibilidade afirma a terceira, mas lhe acrescenta a ideia da possibilidade de uma passio corporis sem que haja o acompanhamento de uma sensação. ${ }^{178}$ O problema dessa solução é ser demais enfática e não resolver o problema proposto de algum nível consciente em determinadas sensações como a apresentada no exemplo do De musica.

Essa tratativa do problema já nos conduz ao que nos interessa, ainda que indiretamente, pois, se pensarmos que existe a possibilidade de voltar-se com um nível de atenção suficiente para a sensação auditiva, então teríamos ato contínuo com a sensação auditiva, uma compreensão dos ritmos ou significados dessa conversa.

Em suma, no que se trata da sensação humana, podemos dizer que ela é acompanhada de certo conhecimento. Acompanhada, bem dito, pois pelo exemplo não podemos dizer que não há uma atenção da alma ali presente, contudo, em alguns casos, trata-se de uma atenção insuficiente para uma compreensão mais plena. Contudo, mesmo absorvido em pensamentos, o ser percipiente tem certa noção da sensação e de que pessoas estão conversando, na medida em que a alma se volta com maior ou menor intensidade para a afecção corporal, tanto maior será o que poderíamos chamar, aproximadamente, de consciência.

O que temos aqui, portanto, é um tipo de conhecimento na sensação que ainda não é científico, mas que sim, merece o título de conhecimento. ${ }^{179}$ Entretanto, o caso da cogitatio parece mais difícil já que, como o afirmamos acima, cogitatio está relacionada com cogito muito utilizado posteriormente para atividades racionais, principalmente por Descartes. Contudo há na cogitatio realmente um pensamento que seja mais do que certa "consciência"? Esse e outros problemas serão tratados no capítulo seguinte. Contudo, antes de tratar desse aspecto da cogitatio resta ver como a sensação incide sobre a cogitatio. Esse último aspecto é mais uma faceta da importância da sensação na concepção agostiniana de ascensão interiorizante.

${ }^{178}$ Ver sobre a seção II.3.2.3.1. O "non latens animam".

${ }^{179}$ Se tomarmos "ato mental" num sentido mais atenuado, não como atividade superior da mens, mas apenas a referência a capacidade humana de conhecimento, então podemos pensar com Rist (1997, p.126) que “[...] nella sensazione, come in altri atti mentali, ravvisiamo l'intenzionalità, per cogliere i cui procedimenti abbiamo bisogno di conoscere non solo il fatto che il corpo sia strumento dell'anima, ma anche come ló debba essere, al fine di svolgere il suo compito adeguatamente". 


\section{A PASSAGEM E "PRESENÇA" DA SENSAÇÃO NA SEGUNDA TRINDADE EXTERIOR}

Para que um capítulo acerca da cogitatio se o presente trabalho trata da sensação? Ao que parece a cogitatio já se encontra em um momento distinto da primeira: trata-se de coisa bem diferente. Contudo, como sugere o título acima, por outro lado, ainda estamos dentro do âmbito das trindades exteriores, e, nosso objetivo com essa pesquisa é percorrer o processo ascensional no âmbito da exterioridade. Ademais, o tratamento da cogitatio não está separado do conjunto do livro XI onde os elementos da exterioridade e da sensação ainda estão presentes, de algum modo, nessa segunda trindade exterior.

No capítulo anterior observamos como a sensação era o processo unificador da primeira trindade exterior. Seguindo essa tese acreditamos que papel análogo desempenha a cogitatio em relação à segunda trindade exterior. A sensação é como que a atividade da primeira trindade exterior, enquanto na segunda trindade mais interior que a primeira, mais ainda exterior, a atividade seria a cogitatio. É a cogitatio que unifica a memória, a visão interior e a vontade.

\subsection{A Cogitatio na Segunda Trindade Exterior}

Até agora defendemos que a sensação é a atividade onde se expressa a identidade entre os três elementos da primeira trindade exterior e que a cogitatio é a atividade na qual estão envolvidos os três elementos da segunda trindade exterior.

A análise da segunda trindade exterior ocupa uma boa parte do livro XI. A não ser por alguns excursos, ela vai de XI, iii, 6 até o final do livro em XI, xi, 18. Para os nossos fins não procuraremos tecer um comentário expositivo sobre a cogitatio. Nossa intenção é apenas mostrar que essa trindade é um momento de transição especial entre a sensação e o pensamento racional e que, nesse sentido, preferimos não traduzir o termo como pensamento, como geralmente é feito, por acreditar que este, em nosso idioma, está muito ligado a um elemento racionalmente mais elaborado, e ainda não sabemos se é disso que trata a cogitatio; apesar de defendermos a tese de que, no ser humano, já no ato de sensação a atividade sensível e o pensamento não podem ser totalmente separados. Assim, quando tratamos da cogitatio talvez seja instrutivo falar em um pensamento que nem sempre é seguido de reflexão, ou um termo melhor, mais ainda impróprio: "consciência” como já usamos para a sensação. 


\subsection{1. É a Cogitatio Pensamento?}

A passagem que basicamente resume a cogitatio é a seguinte:

É assim que, da memória, e da visão interior e da vontade que as une a ambas, se forma aquela trindade; o reunirem-se estas três coisas numa só, chama-se cogitatio a partir da reunião. ${ }^{180}$

Em termos especificamente etimológicos cogitatio está relacionado com o verbo cogito, geralmente traduzido por pensar. Contudo, cogito é formado pelo verbo ago = levar, do qual deriva o verbo coagere-cogere, $=$ juntar. O substantivo coactus é o resultado da ação de juntar, ou seja, a reunião. Assim, cogitatio deriva de coactus, daí a reunião entre os três elementos, memória, visão interior e vontade, é chamada de cogitatio.

Até aqui, ao menos etimologicamente, não temos porque pensar que estamos diante de um pensamento tal como o concebemos comumente. ${ }^{181}$ Temos apenas uma imagem na memória à qual, quando a vontade volta-se para ela aparece a visão interior, que, a nosso ver, não é nada mais que a própria cogitatio, assim como a visão dos objetos externos é o próprio ato da sensação.

Nesse momento podem socorrer-nos as distinções feitas anteriormente entre uisio corporalis e uisio spiritualis. Nossa tese é que a sensação pode ser identificada com a uisio corporalis enquanto a cogitatio com a uisio spiritualis.

Da exposição em 2.3.1.2 acima, mostramos que a uisio spiritualis possui quatro características: 1. Ser alguma coisa; 2. Não ser corporal; 3. Ser uma imagem do corpo ausente (imagem na memória); 4. A visão dessa imagem na memória. Ora, estes todos esses quatro aspectos estão presentes na cogitatio. Mas não paramos aí, ainda se referindo à uisio spiritualis em Gn. Litt.. XII, ix, 20 Agostinho afirma: “... Eu tenho designado como visão espiritual o tipo de visão pela qual nós cogitamos na mente as imagens dos corpos, mesmo na sua ausência"; ${ }^{182}$ agora não há mais dúvidas, certamente quando falamos em uisio spiritualis estamos diante da cogitatio. A referência é necessária para pensarmos a distinção entre cogitatio humana e animal, isso por que essa capacidade também está presente nos animais. Isto é, em parte, deduzido da análise do "sentido interior".

\footnotetext{
180 "atque ita fit illa trinitas ex memoria et interna uisione et quae utrumque copulat uoluntate, quae tria cum in unum coguntur ab ipso coactu cogitatio dicitur". (trin. XI, iii, 6).

${ }^{181}$ Refiro-me aqui a querela sobre a tradução de cogitatio por pensamento, e essa compreensão levada adiante na Idade Média.

182 "secundum hanc, inquam, distinctione spiritale nunc appellauimus tale genus uisorum, quali etiam corporum absentium imagines cogitamos".
} 
Anteriormente na seção em que tratamos do sentido interior no De libero arbitrio, esse sentido servia de intermediário entre a razão e a sensação. Ora, é notável que aqui também a cogitatio esteja situada justamente entre a sensação e a análise da racionalidade científica no livro XII. Contudo, ao analisarmos mais detalhadamente o sentido interior e a cogitatio, percebemos que, ainda que guardem certa relação, se trata de coisas diferentes; na medida em que o sentido interior é uma espécie de capacidade pré-racional que nos habilita a perceber, por exemplo, que temos capacidades sensitivas, não podemos considerá-lo como sensação, mais uma instância superior à mesma. Nada se diz a este respeito da cogitatio, apesar de ser uma capacidade interior partilhada tanto por homens como por animais. Contudo, nesse ponto, Agostinho é muito claro: os animais possuem essa capacidade, mas nem por isso são racionais como o é o homem:

É evidente, também, julgo eu, que o sentido interior não percebe somente os objetos que recebe dos cinco sentidos corporais, mas percebe os sentidos mesmos. Pois o animal não se moveria para buscar um objeto ou para evitálo, se ele não sentisse que sente, não para ter ciência, pois isto é próprio da razão, mas somente para se mover, o que certamente não percebe por um dos cinco sentidos. ${ }^{183}$

Se sentire sentiret, non ad sciendum, nam hoc rationis est. "O animal sente que sente, não para ter ciência, pois isto é próprio da razão". Essa percepção também acontece nos seres humanos, mas igualmente não podemos dizer que se trata de ciência. $\mathrm{O}$ máximo que podemos defender é que no ser humano esta capacidade é acompanhada de da racionalidade.

Antes de adentrar nessas considerações cumpre dizer que, mesmo não sendo idêntico à cogitatio, o sentido interior está relacionado com o mesmo na medida em que ambos fazem parte da interioridade humana não sendo nem corpos, nem sentidos. Assim, ao que parece, cogitatio e sentido interior estão numa posição semelhante de mediação entre a sensação e a razão. Vejamos.

A nosso ver as duas questões estão inter-relacionadas na medida em que, se a cogitatio não é nem sensação, nem racionalidade científica, logo o que ela seria? Ao que podemos dizer que pode se tratar de algum conhecimento, que, no entanto, é inferior à ciência. Da mesma forma, se é uma espécie de conhecimento então de que conhecimento estamos falando?

183 "arbitror etiam illud esse manifestum, sensum illum interiorem non ea tantum sentire quae accepit a quinque sensibus corporis, sed etiam ipsos ab eo sentire. Non enim aliter bestia moueret se uel adpetendo aliquid uel fugiendo, nisi se sentire sentiret, non ad sciendum, nam hoc rationis est, sed tantum ad mouendum, quod non utique aliquo illorum quinque sentit" (De lib. arb. II, iv, 10) 
Conhecimento racional, o pensamento? Ou alguma espécie de consciência animal ou reflexiva? Mais o problema se complexifica se pensarmos que os animais possuem cogitatio.

O problema é relevante e devemos nos perguntar: os animais possuem cogitatio? Ao que tudo indica os animais podem ter uma imagem na memória, gerada a partir do sentido da visão. Sobre a sensação da visão em especial percebemos que, segundo Agostinho, em toda sensação está presente tanto o objeto visto bem como a própria visão e, por fim, vontade. Ora, se os animais possuem sensação logo, pressupõe-se que não só tenham o sentido da visão, mas também uma espécie de vontade. Contudo, não podemos chamá-la de vontade já que, como ficou demonstrado anteriormente, esse movimento animal é associado à ő $\rho \varepsilon_{1}$ เ५ grega e ao appetitus latino, enquanto a vontade está relacionada com o homem racional. Mas então, os animais possuem cogitatio? Se sim ela é a igual à cogitatio humana? A resposta vai no mesmo sentido da distinção entre sensação no homem e sensação nos animais.

\subsubsection{O Papel da Vontade na Distinção Entre Cogitatio Humana e Recordação Animal: Cogitatio Humana como Atividade da Alma Racional.}

O livro XI não trata especificamente da memória animal, contudo, no início do livro XII Agostinho faz uma distinção entre a memória ou recordação animal, em paralelo com a cogitatio humana:

Também os animais irracionais podem não só sentir exteriormente, por meio dos sentidos do corpo, as coisas corpóreas, mas também recordar-se delas, uma vez fixadas na memória e desejar entre elas as que lhe são úteis e fugir das que não lhe convêm. Mas registrá-las, reter na memória não só as que são naturalmente captadas, mas também as que à memória são intencionalmente confiadas, e voltar a imprimir as que começam a cair no esquecimento, recordando-as e cogitando nelas de forma que, assim como do conteúdo da memória se forma a cogitatio, assim também pela cogitatio se consolide precisamente o que a memória contém; construir visões imaginárias, colhendo daqui e dali e como que cosendo algumas recordações; ver de que modo, neste gênero de coisas, as verossímeis se distinguem das verdadeiras, não no que respeita às espirituais, mas precisamente às corpóreas; estas e outras coisas do mesmo gênero, se bem que aconteçam e se passem ao nível das coisas sensíveis e daquelas que o espírito delas colhe pelos sentidos do corpo, nem são desprovidas de razão, nem são comuns a homens e animais irracionais. Mas é exclusivo da mais alta das razões ajuizar destas coisas corpóreas segundo razões incorpóreas e sempiternas que, se não estivessem acima da mente humana, certamente não seriam imutáveis, e, se algo nosso lhes não estivesse submetido, não poderíamos ajuizar das coisas corpóreas em função delas. Ora, nós 
ajuizamos das coisas corpóreas em função do princípio das dimensões e das figuras, princípio que nossa mente sabe que se mantém imutável. ${ }^{184}$

Que há sensação nos animais já o vimos anteriormente. Também que há uma memória animal não é algo difícil de pressupor. Quando comparamos nossas atividades com as deles a evidência parece quase trivial. O exemplo do cão de Ulisses que aparece no De animae quantitate é bem claro em relação a isso: Argos reconheceu Ulisses depois de muitos anos por meio da sua memória das sensações, como, por exemplo, o cheiro de Ulisses. ${ }^{185}$ No texto acima Agostinho afirma claramente que o animal possui uma memória, uma recordação, ou seja, possui uma imagem incorporal na memória e pode manipulá-la também de forma bastante complexa. Contudo, a distinção para com o tipo de memória humana parece ficar bem clara quando Agostinho, após falar da capacidade animal de recordação, insere a conjunção coordenativa de adversidade "sed", um "mas" para estabelecer a oposição entre tal recordação animal e a cogitatio humana:

184 "possunt autem et pecora ete sentire per corporis sensus extrinsecus corporalia et ea memoria fixa reminisci atque in eis appetere conducibilia, fugere incommoda. uerum ea notare ac non solum naturaliter rapta sed etiam de industria memoriae commendata retinere et in obliuionem iamiamque labentia recordando atque cogitando rursus imprimere ut quemadmodum ex eo quod gerit memoria cogitatio formatur, sic et hoc ipsum quod in memoria est cogitatione firmetur, ficta etiam uisiones hinc atque inde recordata quaelibet sumendo et quase assuendo componere, inspicere quemadmodum in hoc rerum genere quae uerisimilia sunt discernantur a ueris, non spiritalibus sed ipsis corporalibus, haec atque huiusmodi, quamuis in sensibilibus atque in eis quae inde animus per sensum corporis traxit agantur atque uersentur, non sunt tamen rationis expertia nec hominibus pecoribusque communia. sed sublimioris rationis est iudicare de istis corporalibus secundum rationes incorporales et sempiternas quae nisi supra mentem humanam essent, incommutabilis profecto non essent, atque his nisi subiungeretur aliquid nostrum, non secundum eas possemus de corporalibus iudicare. iudicamus autem de corporalibus ex ratione dimensionum atque figurarum quam incommutabiliter manere mens nuit"' (trin. XII, ii, 2).

${ }^{185}$ Para tentar provar que os animais possuem conhecimento, Evódio usa o exemplo clássico do cão de Ulisses (HOMERO, Odisseia XVII, 291-327) que teria reconhecido o dono mesmo depois de vinte anos sem vêlo. Para refutar essa tese deve se mostrar que a ciência está relacionada à conjectura ("coniectatum" an. quant. I, xxiii, 45) e não há algo inato como o queria Evódio. A explicação de Agostinho para o exemplo do cão de Ulisses se dará no âmbito puramente anímico e não racional, o que pode surpreender a princípio; para ele, o fato do cão ter reconhecido seu dono depois de tanto tempo se explica pela faculdade de sentir dos animais que é superior/superam (superant) à dos seres humanos: "Esse sentido, que, quando reforçado pela grande força do costume, pode discernir o que dá prazer aos animais, e isso com tanto mais facilidade já que a alma das bestas está mais ligada ao corpo, de quem ela utiliza os sentidos para a alimentação e o prazer físico" "Ille sensus ea quibus tales animae delectantur, accedente consuetudine cuius magna uis est, potest discernere; atque eo facilimus, quod anima belluarum magis corpori affixa est, cuius illi sunt sensus quibus utitur ad uictum uoluptatemque" (an. quant. I, xxvi, 54). Por outro lado, Agostinho faz questão de enfatizar que os seres humanos são superiores aos animais na faculdade racional e no uso dessa faculdade em ato. (an. quant. I, xxvi, 54) "A alma humana, por meio da razão e da ciência, das quais estamos tratando, pelo fato de elas serem superiores aos sentidos, independe do corpo, na medida do possível, e goza mais com o prazer interior; e quanto mais se inclina para os sentidos, tanto mais o homem se assemelha aos animais" "humana uero anima per rationem atque scientiam, de quibus agimus, quod sunt ista longe praestantiora sensibus, suspendit se a corpore quantum potest, et ea quae intus est, libentius fruit uoluptate; quantoque in sensus declinat, tanto magis similiorem hominem pecori facit" idem. 
Também os animais irracionais podem não só sentir exteriormente, por meio dos sentidos do corpo, as coisas corpóreas, mas também recordar-se delas, uma vez fixadas na memória e desejar entre elas as que lhe são úteis e fugir das que não lhe convêm. Mas registrá-las, reter na memória não só as que são naturalmente captadas, mas também as que à memória são intencionalmente confiadas, e voltar a imprimir as que começam a cair no esquecimento, recordando-as e cogitando nelas de forma que, assim como do conteúdo da memória se forma a cogitatio, assim também pela cogitatio se consolide precisamente o que a memória contém; construir visões imaginárias, colhendo daqui e dali e como que cosendo algumas recordações; ${ }^{186}$

"Mas registrá-las, reter na memória não só as que são naturalmente captadas, mas também as que à memória são intencionalmente confiadas [...]”. Já aqui temos a distinção entre as coisas naturaliter confiadas à memória pertencentes ao modo animal de recordação que ajuda no movimento instintivo animal e aquelas que são intencionalmente confiadas à memória: nesse caso relacionada à cogitatio.

Na sequência é narrado todo um processo onde estão presentes elementos ausentes na recordação animal. Neles observa-se uma constante: a presença de elementos intencionais, ou seja, voluntários tais como: manipulação de imagens, construir outras imagens a partir das existentes na memória, querer trazê-las ao pensamento, etc. Todos esses elementos pressupõem uma atividade consciente ausente na recordação animal que visa apenas a reação instintiva e imediata diante da necessidade de preservação da vida. Mas aprofundemos mais essa discussão.

Segundo a descrição da cogitatio humana no livro XI, a visão interior se dá quando a vontade se volta para a imagem guardada na memória. Contudo, essa capacidade permite ao homem uma série de atividades, tais como, por exemplo: formar imagens a partir das imagens guardadas na memória; fixar-se de tal forma numa imagem a ponto de não conseguir distinguir entre a imagem na memória e a imagem na coisa mesma; por fim, ser iludidos por imagem que nos vêm à mente enquanto dormimos (trin. XI, iv, 7). Em todos esses aspectos o papel da vontade é fundamental.

Aquilo que Agostinho chama, desde trin. XI, ii, 2, de animi intentio, ou intenção da alma, é identificado com a vontade a partir de XI, iii, 6. Neste parágrafo, por exemplo, falando da primeira trindade exterior, Agostinho faz ainda mais uma distinção entre a vontade

186 "possunt autem et pecora ete sentire per corporis sensus extrinsecus corporalia et ea memoria fixa reminisci atque in eis appetere conducibilia, fugere incommoda. uerum ea notare ac non solum naturaliter rapta sed etiam de industria memoriae commendata retinere et in obliuionem iamiamque labentia recordando atque cogitando rursus imprimere ut quemadmodum ex eo quod gerit memoria cogitatio formatur, sic et hoc ipsum quod in memoria est cogitatione firmetur, ficta etiam uisiones hinc atque inde recordata quaelibet sumendo et quase assuendo componere". (trin. XII, ii, 2). 
indigna, ou seja, o fixar-se nas imagens sensíveis, que ele identifica com a concupiscência, e a louvável vontade, que é voltar-se para as imagens sensíveis apenas quando essas mesmas imagens tiverem alguma utilidade. ${ }^{187}$ Também o voltar-se para a imagem na memória é chamado de vontade.

Sobre essa capacidade tanto na primeira quanto na segunda trindade exterior Agostinho é claro:

Mas se a vontade, que leva e traz de um para outro lado o olhar a formar e, depois de formado, o une ao seu objeto, toda ela confluir na imagem interior e de todo desviar o olhar do espírito da presença dos corpos que rodeiam os sentidos e dos próprios sentidos do corpo, e o voltar totalmente para a imagem que se vê no interior [...]. ${ }^{188}$

Aqui Agostinho está descrevendo num primeiro momento o papel da vontade da formação da sensação visual que se volta ao seu "bel prazer" para imagens exteriores e formando a visão e num segundo momento essa vontade pode se voltar também ao seu "bel prazer” às imagens já guardadas na memória e não se fixar nas imagens exteriores.

Neste instante não fazemos questão de entrar em intrincados problemas envolvendo a vontade. Para nós basta detectar o seu papel ativo tanto no ato sensitivo quando na cogitatio.

Gilson identifica a vontade como o movimento livre da alma para adquirir ou evitar algo. ${ }^{189}$ Esta asserção parece corresponder justamente ao que acabamos de descrever como a atividade da sensação que é dotada de um motu proprio. Sobre esse aspecto é instrutivo o artigo de Isabelle Koch que faz uma análise precisa e extensiva do papel da vontade na sensação. Para a filósofa francesa nem sempre conseguimos ver a atuação da vontade como movimento livre ali onde ela está presente:

Todos os nossos comportamentos, segundo Agostinho, supõem atividade volitiva. Isso vale certamente para as ações que efetuamos deliberadamente, mas também para atividades que são menos imediatamente identificáveis como atividades voluntárias, por exemplo, a percepção sensível, a imaginação, o sonho, ou ainda o conhecimento racional. (2010, p.74).

\footnotetext{
${ }^{187}$ Ver sobre esse ponto o instrutivo artigo de Isabelle Koch "Augustin et l'usage du monde" in Cahiers Philosophiques 122; $3^{\circ}$. Trim. 2010, p.21-42.

188 "uoluntas uero illa quae hac atque hac fert ete refert aciem formandam coniungitque formatam, si ad interiorem phantasiam tota confluxerit atque a praesentia corporum quae circumiacent sensibus atque ab ipsis sensibus corporis animi aciem omnino auerterit atque ad eam quae intus cernitur imaginem penitus conuerterit [...]" (trin. XI, iv, 7)

189 “"...] o movimento livre da alma para adquirir ou evitar algo é a vontade. Logo, todos os movimentos da alma dependem da vontade" (GILSON, 2006, p.253).
} 
Todos os nossos comportamentos e atividades dependem da vontade. $\mathrm{O}$ termo parece indicar algo mais diretivo, uma atividade consciente. Contudo, a percepção sensível, a imaginação, bem como o sonho e mesmo o raciocínio nos parecem ter, se pensarmos mais trivialmente, um caráter involuntário. Não é assim que Agostinho vê as coisas, ele faz questão de frisar o papel da vontade a cada problema filosófico que pressupõe a ação, não somente as morais, mas também aquelas que se apresentam como aparentemente involuntárias.

Para os nossos propósitos é instrutivo saber que "[...] o caso da percepção permite pensar por extensão outras atividades que dela derivam como, como a rememoração, a imaginação, o sonho" (KOCH, 2010, p. 74). A rememoração, imaginação e o sonho são atividades que dependem da cogitatio. No capítulo anterior, ao tratar do papel da vontade na sensação, já vimos como a vontade racional está presente na percepção descrita aqui por Koch, e, daí parece ser clara a dedução em relação a cogitatio. Se na sensação está presente a distinção entre vontade racional no homem e o appetitus no animal, da mesma forma podemos falar de uma cogitatio humana que é racional e uma recordação animal que, apesar de possuir certo aspecto "judicativo" não pode ser dita racional.

Para Etienne Gilson (2006, p.156). "A cogitatio agostiniana é tão somente o movimento pelo qual nossa alma colige, reúne e recolhe, para poder fixar seu olhar sobre eles, todos os conhecimentos latentes que ela possui sem ainda tê-los discernido". ${ }^{190}$

Esta descrição descreve com clareza e de modo sucinto a fenomenologia da cogitatio. Em primeiro lugar é dito que ela é um movimento, mas, como sabemos, um movimento voluntário, portanto, uma vontade. Sim, uma vontade que une num só ato a imagem na memória e a visão interior. ${ }^{191}$

Em segundo lugar, não podemos afirma que o coligir [coguntur], o reunir [coactus] e o recolher [colligenda ${ }^{192}$ são atos de discernimento. São apenas movimentos da vontade: ${ }^{193}$

Mas se a vontade [...] voltar totalmente para a imagem que se vê no interior, observará que a semelhança da forma corpórea tirada da memória é tão avassaladora que nem a própria razão consegue distinguir se é realmente um

\footnotetext{
190 "Cogitation is te function of man's mind by which he can arrange, collect, and reassemble sense knowledge stored in the memory" (NASH, 2003, p.62).

191 "atque ita fit illa trinitas ex memoria et interna uisione et quae utrumque copulat uoluntate, quae tria cum in unum coguntur ab ipso coactu cogitatio dicitur". (trin. XI, iii, 6).

${ }^{192}$ Ver trin. XI, iii, 6.

193 Aqui obviamente não se fala da distinção sensível como vimos acima no caso dos números juízes que estão na capacidade discernimento instintiva e sensitiva.
} 
corpo que se vê exteriormente ou se é algo semelhante que é cogitado interiormente. ${ }^{194}$

Eis aqui dois momentos específicos: uma cogitatio que se volta para as imagens interiores, extraídas da exterioridade, e nelas fixa o olhar, e, uma razão que tenta discernir [ratio discernere] entre as imagens interiores e as exteriores. Vejamos que o texto não fala em uma ausência da razão, mas sim da dificuldade que esta razão possui ao tentar compreender o limite entre a imagem sensível e a imagem na memória.

Quando pensamos nos graus da alma no De animae quantitate não temos algo parecido com a cogitatio; no segundo e terceiro degraus temos a sensação [sensus] e a arte [ars], sendo que na ars está a scientia, faltaria um lugar entre sensus e ars para a cogitatio que, não pertence nem propriamente à sensação e nem a ars. Ao que parece esse problema ainda não está posto aqui; trouxemo-lo apenas para mostrar apenas que a cogitatio não pode ser considerada como uma atividade do pensamento num sentido mais amplo, já que esse termo pressupõe reflexão e raciocínio, o que não acontece aqui, a não ser que se pense em pensamento num sentido mais atenuado.

Dos argumentos expostos acima, em nosso ponto de vista, pode ser dito da cogitatio a mesma coisa que se afirmou acerca da sensação. Por ser um ato da vontade humana que é livre e deliberativa, tanto no ato da sensação como da cogitatio, se processa internamente uma consciência do que está se sucedendo. Esta fenomenologia da sensação e da cogitatio no ser humano pode ser considerada sim acompanhada de um conhecimento, ainda que não científico, mas que, contudo é racional, ainda que inferior àquele que produz a ciência e acessa a sabedoria.

\subsection{A Sensação na Passagem da Primeira para a Segunda Trindade Exterior}

Talvez, semelhante a Agostinho, nos desviamos um pouco do propósito do presente capítulo, contudo, acreditamos que ele foi frutífero para estabelecer a identidade entre a cogitatio e a sensação na medida em que como atividades da alma humana que é vontade racional também são acompanhadas de certo conhecimento racional.

Mas, esclarecidos esses pontos, agora podemos nos voltar com mais atenção para a importância da sensação na medida em que é crucial para a mediação entre a primeira e a segunda trindade exterior. Tentaremos mostrar a seguir que, sem a primeira trindade exterior

\footnotetext{
194 "uoluntas uero [...] ad eam quae intus cernitur imaginem penitus conuerterit, tanta offunditur similitudo speciei corporalis expressa ex memoria ut nec ipsa ratio discernere sinatur utrum foris corpus ipsum uideatur na intus tale aliquid cogitetur"
} 
não existe uma segunda, e consequentemente, sem a sensação não existe cogitatio. Desse modo, aqui se dá o fechamento do que buscamos argumentar desde o início do presente trabalho: a sensação tem um papel primordial na ascensão na medida em que é o "pontapé inicial" da mesma e, em segundo lugar, e isso é o que trataremos a seguir: oferece as species para a cogitatio.

\subsubsection{As Species como o que Proporciona a Primeira Passagem Ascensional}

No processo de ascensão interiorizante se pressupõe que exista uma passagem. No primeiro capítulo do presente trabalho já mostramos como isso é possível e como, de maneira geral, dá-se a ascensão. Agora, resta mostrar o que proporciona essa passagem. Como afirmamos acima, nossa tese é que são as species, o produto da atividade sensível que nos proporcionam essa possibilidade, ou seja, sem a sensação que produz a specie que permite a passagem para a segunda trindade exterior não há ascensão. O texto central que nos mostra isso está em trin. XI, iii, 6:

[...] removida a forma do corpo que era percebida corporalmente, fica na memória a sua semelhança, para a qual a vontade de novo volte o olhar a fim de que daí o sentido da vista seja enformado interiormente da mesma maneira que era enformado exteriormente a partir do objeto sensível. ${ }^{195}$

O que o texto nos diz? Em primeiro lugar que existe uma forma, o termo latino é specie, percebida corporalmente. Num segundo momento uma specie parece estar na memória, contudo, nesse caso já não se trata mais da mesmíssima specie percebida corporalmente, ou seja, a specie que está presente no sentido da visão. Trata-se da sua semelhança.

Não voltaremos à descrição de como se produz a specie na sensação e nem da passagem da specie presente no objeto da sensação e depois no sentido da visão, pois isso foi feito em toda a seção 4 do segundo capítulo. Contudo, ali não falamos da presença da specie na memória, e, portanto na cogitatio. Esse aspecto não deve ser desprezado, pois é de fundamental importância. Se, como vimos anteriormente, as species [formae ou imagines] ${ }^{196}$ permitem uma espécie de mediação entre o sensível e a alma, a presença das semelhanças das

195 “[...] detracta specie corporis quae corporaliter sentiebatur remanet in memoria similitudo eius quo rursus uoluntas conuertat aciem ut inde formetur intrinsecus sicut ex corpore obiecto sensibili sensus extrinsecus formabatur".

${ }^{196}$ Os três termos são intercambiáveis em Agostinho. O termo imago aparece em De gen. ad litt. XII, xvi, 33, enquanto forma no próprio De trinitate XI, iv, 7 como sinônimo de specie em XI, iii, 6. 
species em cada processo permite que, no processo ascensional, a alma continue sendo resguardada da corporeidade do objeto sensível.

Contudo, isso não é toda a história, a semelhança que uma specie guarda da anterior permite um refinamento na ascensão interiorizante que se torna cada vez menos exterior e mais interior, mais próxima da identidade e distante da alteridade. É isso que nos diz Agostinho ao descrever o processo de progressiva passagem das species (por questões práticas não traduzirei o termo specie):

[...] à specie do corpo que era percebida exteriormente, sucede a memória, que retém a specie de que a alma se impregna por meio dos sentidos do corpo; e à visão, que era exterior, quando o sentido era formado a partir do corpo sensível, sucede interiormente uma visão igual, quando, a partir daquilo que a memória guarda, se forma a visão do espírito e se cogitam os corpos ausentes [...] Assim como pela razão se discernia a specie visível de sua imagem que se criava no sentido formado para ser visão [...] assim também, quando o espírito cogita na specie do corpo que viu, embora aquela (specie) gerada na imaginação seja constituída pela semelhança do corpo que a memória conserva e daquela que dela se forma no olhar do espírito que recorda, todavia aparece uma e aparece singular de tal modo que só pelo juízo da razão - que nos leva a compreender que uma coisa é aquilo que fica na memória, mesmo quando cogitamos a partir de outra coisa, e outra é a que acontece quando recordamos, isto é, quando voltamos à memória e aí encontramos a mesma specie - se reconhece que são duas coisas diferentes. ${ }^{197}$

A sucessão cada vez mais interior se faz por meio da semelhança entre a specie "mais" exterior e a "mais" interior. Nessa descrição de Agostinho temos uma primeira specie no próprio objeto, depois outra no sentido da visão, uma terceira na memória, e, por fim, uma quarta que está na cogitatio que a "pensa" atualmente a specie na memória. Essas quatro species são semelhantes, o que indica que não são iguais. Na verdade elas parecem "apparet", ou seja, aparentam ser uma única coisa, contudo, pela análise racional conclui-se que se trata de coisas distintas.

A specie no objeto certamente é mais exterior à specie na visão, que por sua vez, é mais exterior à specie na memória, mas mais interior que a specie no objeto, e assim por diante.

197 "pro illa specie corporis quae sentiebatur extrinsecus succedit memoria retinens illam speciem quam per corporis sensum combibit anima, proque illa uisione quae foris erat cum sensus ex corpore sensibili formaretur succedit intus similis uisio cum ex eo quod memoria tenet formatur acies animi et absentia corpora cogitantur [...] sicut autem ratione discernebatur species uisibilis qua sensus corporis formabatur et eius similitudo quae fiebat in sensu formato ut esset uisio [...] sic illa phantasia, cum animus cogitat speciem uisi corporis, cum constet ex corporis similitudine quam memoria tenet et ex ea quae inde formatur in acie recordantis animi, tamen sic uma et singularis apparet ut duo quaedam esse non inueniantur nisi iudicante ratione qua intellegimus aliud esse illud quod in memoria manet etiam cum aliunde cogitamus et aliud fieri cum recordamur, id est ad memoriam redimus, et illic inuenimus eandem speciem" (trin. XI, iii, 6) 
Contudo, não esqueçamos, sem a sensação que produz a primeira specie no sentido da visão não há como termos uma specie na memória e, por conseguinte, a specie na visão interior. O que nos mostra que sem sensação, por mais que exista uma specie no objeto exterior à visão corporal. Ou seja, sem a visão corporal que é uma atividade da alma, essa specie jamais poderia “passar”, e ser produzida, por geração semelhante, à visão corporal:

[...] contudo, o corpo não produz a sua imagem no espírito, mas o próprio espírito a produz em si mesmo com rapidez admirável, a qual dista de modo inefável da lentidão do corpo. A imagem do corpo, logo que este for visto pelos olhos, forma-se no espírito de quem vê sem qualquer intervalo de tempo. ${ }^{198}$

Esse argumento é importante na medida em que impede que se pense numa prioridade da specie ou imago sensível do corpo externo como condição da sensação. A condição da sensação é possibilitada, em última instancia, pela presença da alma no corpo humano e não por causa do corpo ou do objeto externo, que, apesar de oferecerem ocasião à sensação, não são responsáveis pela mesma.

Em suma, quando Agostinho proceder à passagem da cogitatio para a scientia nos livros XII e XIII, tratar-se-á de ajuizar as species e imagines das coisas corpóreas por meio das razões eternas e assim prosseguir na introrsum ascendere:

Quando nós deixarmos de lado aquelas coisas que são exteriores aos homens e desejamos subir interiormente a partir das que partilhamos com os gados, antes de alcançarmos o conhecimento das realidades inteligíveis e supremas, que são sempiternas, vem ao nosso encontro o conhecimento racional das realidades temporais. Procuremos descobrir também neste, se pudermos, uma trindade, como a descobríamos nos sentidos do corpo e naquelas coisas que, por intermédio dos mesmos sentidos, se introduziram, sob a forma de imagem, na nossa alma ou no nosso espírito, de tal modo que, em vez das realidades corpóreas que, situadas exteriormente, alcançamos com os sentidos do corpo, pudéssemos ter interiormente, impressas na memória, as semelhanças dos corpos, de que se formasse o conhecimento, com a vontade como o terceiro elemento a uni-las, como exteriormente se formava a visão do olhar, que a vontade, para que a visão acontecesse, dirigia para a

198 “neque ullo modo spiritu praestantius est corpus, imno perspicuo modo spiritus corpore. quamuis ergo prius uideamus aliquod corpus, quod antea non uideramus, atque inde incipiat imago eius esse in spiritu nostro [...] tamen eandem eius imaginem non corpus in spiritu, sed ipse spiritus in se ipse facit celeritate mirabili, quae ineffabiliter longe est a corporis tarditate; cuius imago mox, ut oculis uisum fuerit, in spiritu uidentis nullius pucti temporalis interpositione formatur" (De gen. ad litt. XII, xvi, 33). 
realidade sensível, unindo-as e, também aqui, associando-se a ela como terceiro elemento. ${ }^{199}$

Contudo não se ajuizaria e teríamos um conhecimento, uma ciência acerca das coisas corpóreas sem que estas tivessem sido percebidas pela alma que se utiliza dos sentidos do corpo, ou seja, sem a sensação.

199 "relinquentibus itaque nobis ae quae exterioris sunt hominis et ab eis quae communia cum pecoribus habemus introrsum ascendere cupientibus, antequam ad cognitionem rerum intellegibilium atque summarum quae sempiternae sunt ueniremus, temporalium rerum cognitio rationalis occurrit. etiam in hac igitur inueniamus si possumus aliquam trinitatem sicut ineniebamus in sensibus corporis et in his quae per eos in animam uel spiritum nostrum imaginaliter intrauerunt, ut pro corporalibus rebus quas corporeo foris positas attingimus sensu intus corporum similitudines haberemus impressas memoriae ex quibus cogitatio formaretur tertia uoluntate utrumque iungente, sicut formabatur foris acies oculorum, quam uoluntas ut uisio fieret adhibebat rei uisibili et utrumque iungebat etiam illic ipsa se admouens tertiam" (trin. XII, Xv, 25). 


\section{CONCLUSÕES}

Quando começei a estudar a teoria da sensação no pensamento de Agostinho tudo se descortinava como novo. Tratava-se de um universo a parte. Desde as primeiras pesquisas na iniciação científica até os passos subsequentes do mestrado as descobertas foram trazendo significativas mudanças e esclarecimentos que, por sua vez, marcavam aquilo que existia de distinto na teoria Agostiniana da sensação.

$\mathrm{Na}$ iniciação, ainda preso a uma concepção de sensação enviesada pela leitura que São Tomás fizera de Agostinho, não conseguíamos perceber com clareza que na tratativa agostiniana do problema as bases e o arcabouço conceitual eram bem distintos daqueles que se observava no pensamento tomasiano. Contudo, aos poucos, fomos deixando de lado o Agostinho escolástico, para dar lugar a um Agostinho mais neoplatônico e que afirma a superioridade da alma que não pode sofrer ação externa: convencemo-nos de que, tratava-se não de explicar como encontrar os inteligíveis na e a partir da sensação, e sim de mostrar que a importância da mesma está na alma incorporal que lida com os corporais sensíveis por meio dos órgãos dos sentidos. Ou seja, os sentidos, que são ao mesmo tempo corporais e animados pela alma incorporal, mediam a relação entre alma incorporal e os corpos.

Dessa feita, a conclusão que obtivemos na iniciação científica foi ver a sensação como uma atividade da alma que, para esse fim, se valeria dos sentidos. Contudo, ainda que esse tenha sido o resultado principal da pesquisa, alguns problemas apareceram no decorrer do percurso, em especial o da relação entre conhecimento e sensação. Naquele momento a distinção que Agostinho fizera entre sensus e scientia parecia nos conduzir a uma dicotomia entre sensação e conhecimento.

De posse desses resultados, e também dessas interrogações, decidimos dar prosseguimento à pesquisa. Para isso, a estratégia seria investigar o pensamento maduro de Agostinho. A ideia era ver se existiu ou existiram desdobramentos da dita juventude para a maturidade na sua reflexão sobre esse problema, e foi o que fizemos - para tal se valendo do De trinitate. Em nosso ponto de vista o resultado foi satisfatório em dois sentidos, primeiro como esclarecimento da teoria e, em segundo lugar, pelos desdobramentos que a teoria alcançou no De trinitate.

No primeiro caso, o estudo do De trinitate confirmou que a sensação é uma atividade da alma que vale dos sentidos do corpo. Além disso, a análise do livro XI e uma visada geral do livro XII, ambos em cotejo com o De genesi ad litteram e o De libero arbitrio, permitiram um aprofundamento das relações entre sensação, razão e ciência, mostrando que apesar da 
sensação não poder ser dita ciência, certamente é algum tipo de conhecimento na medida em que é uma atividade da alma humana dotada de uma vontade racional.

No segundo caso, tratando dos desdobramentos da teoria na maturidade, acreditamos que os resultados de certa forma nos surpreenderam. A análise da teoria da sensação no que ela tem de específico no arcabouço do De trinitate, especificamente o livro XI é notável na medida em que podemos perceber como Agostinho conseguiu relacionar toda uma fenomenologia da sensação que tenta preservar a unidade no ato da sensação, com a unidade das operações trinitárias. Percebemos que a identificação da exterioridade com a alteridade e da interioridade com a identidade permitiu a consideração dialética da ascensão interiorizante dentro da doutrina trinitária da inseparabiliter operari - que afirma que em cada atividade de uma das pessoas da trindade estão presentes as outras pessoas divinas. A analogia dessa atividade em relação às tríades humanas mostrou que, mesmo numa orientação exteriorante como é o caso da "primeira trindade exterior", se percebe uma unidade de operação, ainda que os elementos tenham certa distinção de natureza. É a sensação a atividade que unifica os três elementos da trindade exterior. O fato desses três elementos atuarem em conjunto em uma mesma atividade já nos coloca dentro de um processo de interiorização a partir da exterioridade que não pode ser alteridade absoluta.

Esses elementos assim expostos mostram que na análise de uma das atividades mais triviais como a sensação, já podemos começar, pedagogicamente, um processo de ascensão interiorizante que se dá principalmente modo interiori. A sensação como qualquer outra atividade humana pode imitar a atividade trinitária, desde que corretamente considerada.

Por último, fechando a dissertação, pudemos ver como a análise da cogitatio permitiu melhor perceber a importância da sensação como condição de uma progressiva consideração de análises mais aprofundadas e cada vez mais próximas da identidade. Nesse caso, as species obtidas na sensação visual serviram de ocasião para o prosseguimento da introrsum ascendere que se refina pela análise da cogitatio, da cogitatio para a scientia e da scientia para a sapientia.

Por todos esses elementos acreditamos que o presente estudo conduziu-nos a confirmação da tese de que há sim desdobramentos da teoria da sensação no pensamento maduro de santo Agostinho e que estes não são de somenos importância, muito pelo contrário, revelaram ao menos um aspecto antes ignorado em uma análise das tríades que imitam a trindade: a importância da doutrina da inseparabilidade das operações divinas, que, para nós, é a chave de leitura para se entender a sensação e outras atividades humanas que imitam a Trindade. De tudo isso, podemos afirmar que a sensação possui relevância filosófica dentro 
do pensamento de Agostinho de Hipona. Para nós, essa atividade trivial, antes desprezada, tornou-se ocasião para uma rica reflexão de assuntos elevados.

São esses os resultados de nossa pesquisa e que trazemos à consideração dos estudiosos de Agostinho e do público. Esperamos que sejam ocasião de críticas e contribuam para o debate e divulgação do pensamento de Agostinho, em específico o tema da sensação, e quem sabe, das influências que ele exerceu na posteridade. 


\section{BIBLIOGRAFIA}

\section{FONTES PRIMÁRIAS}

AUGUSTINUS HIPPONENSIS. La grandezza dell'anima: il De quantitate animae e la quaestio de anima nel De genesi ad litteram. Introd., traduzione e note a cura di Paola Pascucci. Piccola Biblioteca Agostiniana, 44. Roma: Città Nuova, 2009. 294 p.

. Dialoghi. La grandezza dell'anima; Il libero arbitrio; La musica; Il maestro. Intr. A . Trapè. Tr. D. Gentili. Nuova biblioteca agostiniana. Opere de Sant'Agostino, III(2): Opere filosofiche-dommatiche. Roma, Città nuova, 1992. 846 p.

. Obras filosoficas: Contra los académicos. El libre albedrío. La dimensión del alma. El maestro. Naturaleza y origen del alma. La naturaleza del bien. $5^{\text {a }}$. ed. Tr. Introduccion y notas V. Capanága et al.. Obras completas de Sto. Agustín, III. Ed. bil.. BAC. Madrid: Editorial Catolica. 1982.

. Dialogues philosophiques. Contra academicos. Contre les académiciens. De beata vita. Du bonheur. De ordine. De l'ordre. Texte latin de l'éd. bénédictine. Intr., tr. et notes par R. Jolivet. Bibliothèque augustinienne. Euvres de saint Augustin, 4. Paris, Desclée de Brouwer, 1939. 1941. 1948. 1954. 459 p.

. Dialogues philosophiques, II. Dieu et l'âme. Soliloques. Les soliloques. De immortalitate animae. L'immortalité de l'âme. De quantitate animae. La grandeur de l'âme. Texte latin de l'éd. bénédictine. Intr., tr. et notes de P. Labriolle. Bibliothèque augustinienne. Euvres de saint Augustin, 5. Paris, Desclée de Brouwer, 1939. 1947. $415 \mathrm{p}$.

. Dialogues philosophiques, III. De magistro. Le maître. De libero arbitrio. Le libre arbitre. Éd. entièrement nouvelle avec intr., tr. et notes par G. Madec. Bibliothèque augustinienne. Euvres de saint Augustin, 6. Paris, IEA, [1976] 1999. 608 p.

. Dialogues philosophiques, IV. De musica. La musique. Texte latin de l'éd. bénédictine. Intr., tr. et notes de G. Finnaert et F.-J. Thonnard. Bibliothèque augustinienne. Euvres de saint Augustin, 7. Paris, Desclée de Brouwer, 1947. 546 p.

. AUGUSTIN, Dialogues philosophiques, III. De magistro. Le maître. De libero arbitrio. Le libre arbitre. Éd. entièrement nouvelle avec intr., tr. et notes par G. Madec. Bibliothèque augustinienne. Euvres de saint Augustin, 6. Paris, IEA, [1976] $1999^{3} .608 \mathrm{p}$.

AUGUSTIN D’HIPPONE, De Genesi ad litteram libri duodecim. La génèse au sens littéral 
en douze livres. Intr., tr. et notes par P. Agaësse et A. Solignac. Bibliothèque augustinienne, Euvres de saint Augustin, 48-49. Paris, IEA, [1972] 2001-2002² 2 vols.

. Les Confessions. Texte de l'édition de M. Skutella. Intr. et notes par A. Solignac. Tr. de E. Tréhorel et G. Bouissou. Bibliothèque augustinienne. Euvres de saint Augustin, 13-14. Paris, IEA, [1962] repr. 1998-1996. 2 vols.

La Trinité: livres I-VII. Texte de l'édition bénédictine. Avant-propos par G. Madec. Tr. et notes par M. Mellet et Th. Camelot. Intr. par E. Hendrickx. Bibliothèque augustinienne. Euvres de saint Augustin, vol. 15. Paris, IEA, 1955.

. La Trinité: livres VIII-XV. Texte de l'édition bénédictine. traduction par P. Agaësse ; notes en collaboration avec J. Moingt. Bibliothèque augustinienne. Euvres de saint Augustin, 1. Paris, IEA, 1997.

. De trinitate book 8-15. Edited by Gareth B. Matthews; translated by Stephen McKenna. Cambridge, UK; New York: Cambridge University Press, 2002. (Cambridge texts in the history of philosophy).

. Trindade (De trinitate). Coordenação Arnaldo do Espírito Santo. Introdução e notas José Maria da Silva Rosa. Tradução Arnaldo do Espírito Santo; Domingos Lucas Dias; João Beato; Maria Cristina de Castro-Maia de Sousa Pimentel. Prior Velho: Paulinas, 2007.

. De civitate dei contra paganos libri XXII. PL Tomus 41, 1983.

. De diversis quaestionibus octoginta tribus; De octo dulcitii quaestionibus. Ed. A. Mutzenbecher. CCSL, 44A. Turnholt, Brepols, 1975. CXLVI+367 p.

. Discorsi 273-340/A (sui $i$ santi). Intr. A. Quaequarelli; tr. M. Recchia. Nuova biblioteca agostiniana. Opere de Sant'Agostino, XXXIII: Discorsi, 16. Roma, Città nuova, 1986. LXV+1100 p.

AURELIUS AUGUSTINUS, Epistulae I-LV. Ed. K.-D. Daur. CCSL, 31. Turnhout, Brepols, 2004. XXXVIII+268 p.

AURELIUS AUGUSTINUS, De utilitate credendi. De duabus animabus. Contra Fortunatum Manichaeum. Contra Adimantum. Contra epistulam fundamenti. Contra Faustum Manichaeum. Recensuit I. Zycha. CSEL, 25, 1. Pragae - Vindobonae, F. Tempsky / Lipsiae, G. Freytag, 1891. LXXXVI+801 p. (In Library of Latin Texts. Series A. Cetedoc. Turnholt, Brepols, 2008. Sur/on dvd version 7). 


\section{FONTES CLÁSSICAS}

ARISTOTE. De Anima. $2^{\mathrm{a}}$. edição. Apresentação, tradução e notas de Maria Cecilia Gomes dos Reis. São Paulo: Editora 34, 2012.

HOMERO. Odisseia. $2^{\text {a }}$. ed. Tradução, posfácio e notas de Trajano Vieira; ensaios de Italo Calvino. São Paulo: 34, 2012. (edição bilíngue, português e grego)

PLATONIS. La République. Tome VII lère partie: livres IV-VII. Paris: Belles Lettres, 1961 (Bilíngue).

PLOTINUS. Enéadas: libros III y IV. Madrid: Editorial Gredos. 1985

Enéadas: libros V y VI. Madrid: Editorial Gredos. 1998

. The Enneads. Stephen Mackenna, and B. S Page 3d ed. London: Faber and Faber, 1962.

. Ennéades. Emile Bréhier Paris: Société d'édition "Les Belles Lettres", 1956.

\section{FONTES SECUNDÁRIAS}

ARENDT, Hannah. $O$ conceito de amore $m$ Santo Agostinho: ensaio de interpretação filosófica. Lisboa: Instituto Piaget, 1997. (Pensamento e Filosofia, v.13).

BANNER, William Augustus. The path of St. Augustine. Lanham; London: Md. Rowman \& Littlefield, 1996.

BELLO, Angela Ales. Introdução à fenomenologia. Bauru: Edusc, 2006. (Coleção Filosofia e Política).

BERMON, Emmanuel. Le cogito dans la pensée de Sant Augustin. Paris: J. Vrin, 2001 (Histoire des doctrines de l'antiquité classique, XXVI).

BERMON, Emmanuel. A teoria das paixões em santo Agostinho, pp.199-242 in BESNIER, Bernard; MOREAU, Pierre-Fraçois; RENAULT, Laurence. As paixões antigas $e$ medievais: teorias e críticas das paixões. São Paulo: Loyola, 2008.

BOURKE, Vernon Joseph. Augustine's love of wisdom an introspective philosophy. West Lafayette, Indiana: Purdue University Press, 1992. . Wisdom from St Augustine. Houston, Texas: Center for Thomistic Studies, University of St. Thomas, 1984. 
BOUTON-TOUBOULIC, Anne-Isabelle. L'ordre cache: la notion d'ordre chez saint Augustin. Paris: Brepols (Institut d’Études Augustiniennes), 2004.

BRACHTENDORF, Johannes. Confissões de Agostinho. São Paulo: Loyola, 2012.

BRÉHIER, Émile. Historia de la filosofia: tomo I Introducción general, la filosofia em oriente, período helênico, período helenístico y romano. Traducción por Demetrino Náñez. Buenos Aires: 1962. La philosophie de Plotin. Nouvelle édition. Paris: Vrin, 1961.

BROMURI, Elio. La analogie trinitari di S. Agostino tra psicologia e mística In: Congresso Internazionale su S. Agostino nel XVI Centenario della Conversione; Roma, 15 - 20 settembre 1986: atti II Sezioni di Studio II-IV. Roma: Institutum Patristicum “Augustinianum”, 1987. (Studia Ephemeridis “Augustinianum” 25). p. 169-185.

BUBACZ, Bruce. St. Augustine's theory of knowledge: a contemporary analysis. Lewiston NY: The Edwin Mellin Press. 1981.

BURT, Donald X. Augustine's wordan introduction to his speculative philosophy. Laham: University Press of America, 1996.

CAYRÉ, Fulbert. Initiation a la philosophie de saint Augustin. Paris: Études augustiniennes, 1947.

CILLERAI, Beatrice. La memoria come capacitas Dei secondo Agostino: unità e complessità. Firenze: Edizioni ETS, 2008. (philosophica 47).

COURCELlE, Pierre Paul. Recherches Sur Les Confessions De Saint Augustin. Paris: E. de Boccard, 1950.

DARTIGUES, André. O que é a fenomenologia? 2a . ed. Rio de Janeiro: Eldorado, 1973.

DOUBY MÚGICA, María del Carmen. El hombre es imagem de Dios: visión antropológica de San Agustín. Pamplona: Ediciones Universidad de Navarra, 2002.

DOUCET, Dominique. Augustin: l'expérience du verbe. Paris: J. Vrin, 2004.

DULAEY, Martine. Le revê dans la vie et la pensée de saint Augustin. Paris: Études Augustiniennes, 1973.

DU ROY, O. L'intelligence de la foi en la trinité selon saint Augustin: genèse de sa théologie trinitaire jusqu'en 391. Paris: Études Augustiniennes, 1966.

EVANS, G. R. Augustine on evil. Cambridge: University Press, 2000. 
FONTANIER, Jean-Michel. La beauté selon saint Augustin. Rennes: Press Universitaires de Rennes, 1998.

FORMAN, Robert J. Augustine anf the making of a christian literature classical and Augustinian aesthetics. Lewiston: The Edwin Mellen Press, 1995.

FUJISAKA, Daniel. Agostinho e os maniqueus: análise a partir "das duas almas". 2014. Dissertação (Mestrado em Filosofia) - Universidade de São Paulo, São Paulo, 2014.

GAZOLLA, Rachel. O ofício do filósofo estoico: o duplo registro do discurso da Stoa. São Paulo: Loyola, 1999.

GILSON, Etienne. Introdução ao estudo de santo Agostinho. tradução Cristiane Negreiros Abbud Ayoub. São Paulo: Discurso Editorial; Paulus, 2006.

. Por que são Tomás criticou santo Agostinho; Avicena e o ponto de partida de Duns Escoto. São Paulo: Paulus, 2010.

GIOIA, Luigi. The theological epistemology of Augustine's "De Trinitate”. Orford: Oxford Univ. Press, 2009. . Filosofia e incarnazione in sant'Agostino. Presentazione e traduzione di Luigino Zarmati. Roma: Casa editrice Leonardo da Vinci, 1999.

GRANDGEORGE, L. Saint Augustin et le neo-platonisme. Paris: Minerva, 1967.

HADOT, Ilsetraut. Arts libéraux et philosophie dans le pensée antique: contribution à l'histoire de l'éducation et de la culture dansl'antiquité. Paris: Librairie philosophique J. Vrin, 2005.

HANKINSON, R. J. Epistemologia estoica. In INWOOD, B. (Org.). Os estóicos. Tradução Raul Fiker. São Paulo: Odysseus Editora, 2006. p. 65-94.

HOMBERT, Pierre-Marie. Nouvelles recherches de chronologie augustinenne. Paris: Institut d'Études Augustiniennes, 2000. (Collection des Études Augustiniennes, v. 163).

HULTGREN, Gunnar. Le commandement d'amour chez Augustin: interpretation philosophique et théologique d'aprés les ecrits de la période 386-400. Paris: Vrin, 1939.

JUNG, Carl Gustav. Tipos psicológicos. Petrópolis: Vozes, 1991.

KOCH, Isabelle. Sobre o conceito de voluntas em santo Agostinho. In Discurso, São Paulo, n. 40, p. 71-94, anual. 2010. 
LONG, A. A. Soul and Body in Stoicism. Phronesis, v. 27, n. 1, p. 34-57, 1982.

MACDONALD, Scott. Augustine's Cognitive Voluntarism in De Trinitate 11. In: BERMON, Emmanuel; O’DALY, Gerard J. P. Le De trinitate de saint Augustin: exegese, logique et noétique: actes di colloque international de Bordeaux, 16-19 juin 2010. Paris: Institut d'Études Augustiniennes, 2012. (Collection des Études Augustiniennes, Série Antiquité, 192). p. 235-250.

MADEC, Goulven. Ascencio, ascensus. In MADEC, Goulven. Petites études augustiniennes. Paris: Institut d'Études Augustiniennes, 1994. p.137-149. Le Dieu d'Augustin. Paris: Ed. du Cerf, 2000. . Chez Augustin. Paris: Institut d'Études Augustiniennes, 1998.

MAMMI, Lorenzo. Santo Agostinho, o tempo e a música. 1998. Tese (Doutorado em Filosofia) - Universidade de São Paulo, São Paulo, 1998. 2 vol.

MARROU, Henri-Irénée. Saint Augustin et la fin de la culture antique. Paris: Boccard, 1938.

MATTHEWS, Gareth, B (Ed.). Augustine: on the trinity books 8-15. Translated by Stephen McKenna. Cambridge; New York; Port Melbourne; Madrid; Cape Town: Cambridge University Press, 2006. (Cambridge texts in the history of philosophy).

MAYER, Cornelius P. (org.). Augustinus-Lexicon.Basel; Stuttgart: SchwabeVerlag, 1986 ss., p.XXVI-XL.

MORALES, Xavier. La théologie trinitaire d'Athanase d'Alexandrie. Paris: Institut d'Études Augustiniennes, 2006. (Collection des Études Augustiniennes, Série Antiquité, v. 180).

MOREAU, Joseph. Plotin ou la glorie de la philosophie antique. Paris: Vrin, 1970.

MOREL, Pierre-Marie. La sensation, messagère de l'âme. Plotin, V, 3 [49], 3. In DIXSAUT, Monique (Dir.). La connaissance de soi: etudes sur le traité 49 de Plotin. Paris: Vrin, 2002. p.209-227.

NADEAU, Christian. Le vocabulaire de saint Augustin. Paris: Ellipses, 2001.

NASH, Ronald H. The light of the mind: St. Augustine's theory of knowledge. Lima, OH: Academic Renewal Press, 2003. 
NOVAES FILHO, Moacyr Ayres. O livre arbitrio da vontade humana e a presciência divina, segundo Agostinho de Hipona. 1997. Tese (Doutorado em Filosofia) - Universidade de São Paulo, São Paulo, 1997. . Interioridade e inspeção do espírito na filosofia agostiniana. Analytica, Rio de Janeiro, v. 7, n. 1, 2003. . A razão em exercício: estudos sobre a filosofia em Agostinho. São Paulo: Discurso Editorial. 2007.

O’DALY, Gerard. Augustine's philosophy of mind. Berkeley: University California Press, 1987.

. The responde to skepticism and the mechanisms of cognition. In STUMP, Eleonore; KRETZMANN, Norman (Eds.).The Cambridge companion to Augustine. Third printing. Cambridge; New York; Port Melbourne; Madrid; Cape Town: Cambridge University Press, 2004. pp. 159-170.

. Platonism pagan and christian studies in Plotinus and Augustine. V.1. Burlington: Aldershot Ashgate, 2001.

PANNENBERG, Wolfhart. Teologia sistemática vol I. trad. Ilson Kayser. Santo André: Academia Cristã; São Paulo: Paulus, 2009.

PARENTE, Margherita Isnardi. Introdução a Plotino. Trad. José Francisco Espadeiro Martins. Lisboa: Edições 70, 2005.

PRZYWARA, Erich. Augustin, passions et destins de l'occident. Paris: du Cerf, 1987.

QUINN, John M. A companion to the confessions of St. Augustine. New York: P. Lang, 2007.

RIST, John M. Agostino: il battesimo del pensiero antico. Traduzione di Elisabetta Alberti; revisione di Giuseppe Girgenti. Milano: Vita e Pensiero, 1997.

SAARINEN, Risto. Weakness of the will in medieval thought from Augustine to Buridan. Leiden; New York: E. J. Brill, 1994.

SCIACCA, Michele F. El compuesto humano en la filosofia de San Augustin. Ciencia y fe. San Miguel, año X, nº 40, p. 7-24, oct./dic. 1954. Saint Augustin et le neoplatonisme: possibilite d'une philosophie chretienne. Paris: Beatrice-Nauwelaerts, 1956. 
SESBOÜÉ, Bernard. História dos dogmas: o Deus da salvação, vol 1. São Paulo: Loyola, 2002. (História dos dogmas).

TRAPÈ, Agostino. Introduzione generale a Sant'Agostino. Roma: Città Nuova, 2006. . Agostino: introduzione alla dottrina della grazia. Roma: Città Nuova, 1987. (Nuova Biblioteca Agostiniana).

WHITE, Michael J. Filosofia natural estoica. In INWOOD, B. (Org.). Os estóicos. Tradução Raul Fiker. São Paulo: Odysseus Editora, 2006. p. 171-198.

ZUM BRUNN, Emile. Le dileme de l'être et du néant chez Saint Agustin: des premiers dialogues aux “Confessions”. Amsterdam: Grûner, 1984. 